\title{
Cellular and Molecular Mechanisms
}

\section{of Pain Control by Opiates}

by

Daniel W. Beacham

A Dissertation

Presented to the Neurosciences Graduate Program and the Oregon Health Sciences University

School of Medicine

in partial fulfillment of

the requirements for the degree of

Doctor of Philosophy

December 2001 


\section{Table of Contents}

Table of Contents

Dedication

Acknowledgements $\quad$ V

Abstract $\quad$ vi

Introduction 1

Pain transmission 1

I. Peripheral mechanisms 1

II. Central mechanisms

$\begin{array}{ll}\text { Pain modulation } & 7\end{array}$

$\begin{array}{ll}\text { I. Peripheral mechanisms } & 7\end{array}$

II. Central mechanisms 9

$\begin{array}{ll}\text { Opioid Peptides and Receptors } & 11\end{array}$

I. Molecular Biology 11

II. Cellular Biology 13

$\begin{array}{ll}\text { Sensory neurons revisited } & 15\end{array}$

$\begin{array}{ll}\text { Practical approaches to difficult questions } & 15\end{array}$

Do MOR levels control analgesia? 16

Do other opioid receptors contribute to analgesia? 17

$\begin{array}{lc}\text { Materials and methods } & 18\end{array}$

$\begin{array}{lr}\text { I. Practical } & 18\end{array}$

$\begin{array}{ll}\text { II. Recipes } & 35\end{array}$ 
Results Chapter I. Opiate specificity of nociceptors determined by their level of mu opioid receptor mRNA 46

$\begin{array}{ll}\text { Abstract } & 47\end{array}$

$\begin{array}{ll}\text { Introduction } & 48\end{array}$

Figure 1. Opiate analgesia and nociceptor identification 53

$\begin{array}{lr}\text { Results } & 54\end{array}$

Figure 2. Opioids inhibit calcium channels on nociceptive, but not non-nociceptive, sensory neurons

Table 1. MOR sensitivity and mRNA in Nociceptive and non-nociceptive sensory neurons

Figure 3. Use of competitive RT-PCR to quantify single cell MOR and GPD mRNAs

Figure 4. Most nociceptors, but only rare mechanosensors, transcribe MOR mRNA

Figure 5. Large nociceptors have low opioid response and have low MOR mRNA levels

Figure 6. Opioid sensitivity is limited when MOR mRNA is below $15 \mathrm{pM}$

Summary

Results Chapter II. Dynorphin modulation of sensory and locus coeruleus neurons through the mu opioid receptor

Abstract

Introduction 
Figure 1 . Rat sensory neurons respond identically to DAMGO and dynorphin

Figure 2. Few cells contain KOR mRNA

Figure 3. A selective MOR antagonist blocks the dynorphin

$$
\text { response }
$$

Figure 4. A rare cell that responds to the KOR selective agonist U-69593

Figure 5. Dynorphin-induced hyperpolarization of LC neurons is mediated by MOR

Discussion I. MOR control of opiate analgesia

Figure 1. Opioid sensitivity of most nociceptors is RNA- limited 


\section{Dedication}

I have a few people to thank for any success that comes of this work. For me, the true difficulty in practicing science has always come when the experiments are completed, and all the thrill of discovery at the bench is past. In fact, the real work still remains, where you have to synthesize your findings into a single package and then tell the story to the world in the cumbersome language of scientific communication. I have never felt very good at this part. Were it not for the coaching, cheerleading, and occasional bullying of my advisor, Edwin McCleskey, I might not have ever felt very good at it, and I still worry that my dissertation will read more like Richard Scary's Big Book of Patch Clamp Studies with Opioids than a work worthy of publication in the journals we all like to read. Think of how rare it is that you find an article enjoyable. Anyway, I have to thank Ed for helping me to finish this thing, belated as it is in coming. I also have to give thanks for his patience, boundless zeal, and superb sense of quality, which I hope that I can bring to everything I do.

I especially want to thank my family and all of my friends, who have seen me through so much and helped me to keep a sense of humor about myself. As much as anything ever was, this is for my father. 


\section{Acknowledgements}

I have had the pleasure of collaborating with two other investigators in the projects described here. For the work described in the first results chapter, Seth Silbert and I worked together every day for eight months, perfecting a method to electrically record and subsequently measure opioid receptor message in single sensory neurons with fidelity. In the second results chapter, Dr. Laura Stone did the recordings from locus coeruleus neurons that are shown in figure five.

Three technicians did much of the cell culture. Stephi Sutherland, Vu Dang, and Michelle Bobo have all slaved away in the culture hood for our lab, and without their help, things would have gone much more slowly.

I also want to thank my advising committee for their helpful input and patience, particularly John Williams and Craig Jahr for their open doors. (Thank you also to Richard Walker and to Henrique von Gersdorff for agreeing to sit my exam on such short notice. I hope it is worth your while.) Other scientists whose help, discussion, and bluesky idea sessions in the second floor conference room and at the Vollum happy hour have been invaluable to me are listed here in no particular order: Sean Cook, Stephanie Sutherland, Derek Molliver, Dave Immke, Matt Jones, Jeff Diamond, Steve Tavalin, Gursharn Khatra, Ken Tovar, and Willie Lensch. Especially big thanks to Ed Perl and Thom Segerson for guidance and friendship. 


\begin{abstract}
Most prescribed analgesics take advantage a complex and dynamic opioid neurotransmission system endogenous to all mammals, capable of relieving the pain of a recent injury while leaving other sensations intact. At analgesic doses, the opiate morphine selectively activates the mu opioid receptor (MOR) and produces a similar pain block. The goal of section I of this dissertation is to explain this phenomenon. Using an MOR agonist called DAMGO, we measured the electrical inhibition caused by this opioid peptide in pain sensing (nociceptor) sensory neurons that we put into culture. This is our in vitro model for the block of pain transmission by opioids. We then correlated the size of this inhibition on individual nociceptors with the level of MOR expression as measured by quantitative single cell RT-PCR. Despite the obvious involvement of numerous proteins in the MOR signaling pathway, we found that the levels of MOR mRNA in nociceptors solely dictated their susceptibility to electrical modulation by DAMGO. We then asked if non-nociceptors expressed DAMGO responses or MOR, and found that they did not. While this may seem like a small surprise, that the opiate sensitivity of nociceptors is under the fine control of a molecule that is not expressed in non-nociceptors, this result supports a simple explanation of a complex behavior with a history of controversy. The selective block of pain by morphine and opioid peptides is likely not the result of action at some higher center in the pain pathway. Primary sensory neurons are themselves the biological substrates of morphine analgesia. The tightly controlled expression levels of a single molecule likely cause the selective inhibition of pain signals by opiates and endogenous opioid peptides.
\end{abstract}


Two other opioid receptor subtypes have been identified, delta and kappa opioid receptor (DOR and KOR). Since cells did not respond to the DOR-1 agonist DPDPE in our studies, section II of this paper was an investigation of the kappa opioid receptor (KOR) on sensory neurons. Our lab and others have reported that many cells respond to dynorphin, an endogenous KOR agonist, and therefore assumed that KOR is commonly expressed by sensory neurons. Surprisingly, we found that the magnitude of the dynorphin and DAMGO responses on most cells was nearly always identical. However, few cells contained measurable levels of KOR mRNA. Using selective KOR selective antagonists, we found that dynorphin responses on nearly all sensory neurons were mediated through the MOR, and that KOR expression on sensory neurons was in fact quite rare. Dynorphin was also capable of stimulating MOR activation of potassium channels in locus coeruleus slices, a tissue completely devoid of KOR. This told us that the sensory neuron MOR is not uniquely sensitive to dynorphin. This finding further reinforces the hypothesis that MOR is the dominant opioid receptor on nociceptor sensory neurons, and that its expression is sufficient to explain morphine analgesia as well as the sensitivity of these important cells to multiple endogenous opioid agonists. 


\section{Introduction}

Opioid peptides and their receptors mediate numerous biological processes in normal and pathologic conditions, but are best known for their ability to block pain. In this chapter, we will review known facts and current hypotheses about pain and the mammalian opioid system, and propose a means to ask how morphine and endogenous opiates can effect the blockade of pain signals while leaving other sensations intact. We will also propose experiments to ask about the importance of opioid receptor subtypes expressed by sensory neurons. Following the introduction, the methods section will describe how these questions can be asked in the laboratory, and the results chapters one and two will describe and summarize our findings. At the end of the paper, there will be discussions of each of the results chapters with proposed future directions and conclusive statements.

\section{Pain Transmission}

I intend this section to serve as a very basic primer for visiting guests of sensory biology. I have divided it into two halves, the first half describing the peripheral substrates of pain signaling, and the second half describing central pathways that relay pain information along ascending systems.

\section{Pain Transmission I- Peripheral Mechanisms}

This section is about the primary circuit element in the pain pathway, the sensory

neuron. Sensory neurons are the conscious mind's interface with the physical world. For every sensation that we are aware, and several that we are not, there exist sensory neurons or specialized structures innervated by sensory neurons that detect specific environmental stimuli and communicate information about them to the central nervous 
system. For the purposes of this discussion, we will not review sensory neurons outside the realm of somatic, or body-sensations, i.e. warmth, pressure, discomfort, and body position. In the context of somatic sensory neuron activity, we refer to these sensations as modalities of transmission. Photosensitive neurons of the retina, chemosensitive neurons of the olfactory epithelium, and acoustic-mechanic sensitive cells of the cochlea respectively communicate the familiar sensations of sight, smell, and sound to the brain, but do so through highly specialized structures which are incapable of relaying more than one kind of signal. Somatic sensory neurons make up a broad class of peripheral neurons that communicate diverse stimuli to the spinal cord along distinct classes of afferent fibers. The activity and firing pattern of each cell encodes a specific modality to the organism that is interpreted in the central nervous system as a sensation.

There are a variety of touch-sensitive fibers, called mechanosensors, muscle displacement-sensitive fibers, called proprioceptors, warm- and cooling sensitive fibers, and several classes of tissue damage-sensitive fibers, called nociceptors. Each cell type expresses a unique array of molecular and/or endorgan detector elements at its site of peripheral innervation, specializing each cell to detect specific stimuli. Mechanosensors innervate structures called corpuscles that convert skin touch information into electrical activity, and proprioceptors innervate structures called muscle spindles that encode muscle displacement data with their activity. The peripheral processes of nociceptors typically terminate in bare nerve endings, and are thought to be activated by extremes in temperature and pressure, as well as by chemicals that are released from nearby cells when they are damaged or stimulated to secrete algogenic substances. Only recently have we begun to work out a molecular basis for the ways that nociceptors detect tissue 
damage, (McCleskey and Gold 1999) and after decades of research, the selective inhibition of nociceptor sensory neurons remains a hotly explored means of pain treatment with obvious advantages for patients in need of pain relief.

There are numerous sensory neuron phenotypes and categories, with a wide variety of electrical and chemical signatures (Elde, Arvidsson et al. 1995; Djouhri, Bleazard et al. 1998; McCleskey and Gold 1999; Waxman, Cummins et al. 1999). While modern methods have allowed for ever more specialized categorization of sensory neurons based on peptide content, expression of receptors for neurotrophins, plant lectins, and chemical mediators, sensory neurons have classically been distinguished from each other with a basic and very functional assay: the conduction velocity of their afferent fibers. Some sensations are transmitted rapidly, and some are transmitted slowly. An afferent fiber's caliber and degree of myelination are the main determinants of its conduction velocity, and at the extremes of cell body size, the caliber and myelination of sensory afferents correlate with the diameter of their cell body size (Harper and Lawson 1985; Lee, Chung et al. 1986). Large sensory neurons $>40$ microns in diameter usually have large caliber, myelinated peripheral processes. They transmit data about immediately sensed events like touch, proprioception, and pinprick pain at conduction velocities upwards of 70 meters per second. Because these fibers generate the first waveform to cross the oscilloscope when one records from them in an intact-nerve preparation such as microneurography, they are referred to as "A" fibers. There are further sub classifications of A fiber, again based on conduction velocity, called $\mathrm{A}_{\alpha}$ and $A_{\beta}$, whose activity encodes mechanosensation and proprioception, while $A_{\delta}$ fibers conduct rapidly transmitted heat information. These rapidly transmitting fibers that are 
specialized for detecting noxious stimuli relay "first pain" information and they mediate the fast reflex and noxious withdrawal pathways necessary for the prevention of injury when a small pain stimulus activates them.

Small diameter sensory neurons with cell bodies $<30$ microns in diameter have fine caliber, thinly myelinated or unmyelinated "C" fiber processes in vivo, which slowly transmit lasting, or "second pain" information from the periphery with conduction velocities of 0.5-2 meters per second. These fibers have long been a focus of pain research, since they underlie the sensation of pain that follows an injury, preventing the organism from causing further tissue damage while in convalescence. They are often silent to all but tissue-damaging stimuli (Burgess and Perl 1967), and their activation results in prolonged discharge to the spinal cord and sensitization of central pain pathways (Woolf and Salter 2000). C fibers are of particular interest to clinicians because they relay pain signals that can be blocked by opiates, which despite numerous side effects, remain the best available treatment for severe pain.

Sensory neurons are easily dissected for convenient study in acute or long term culture, but once they are cut away from their central and peripheral nerve endings, digested in enzymes and disbursed onto culture dishes, all information about their modality in vivo is lost. Our laboratory has taken advantage of vital dye labeling methods to allow studies of identified damage sensing, proprioceptive and ischemia-detecting sensory neurons in culture (Taddese, Nah et al. 1995; Cook, Vulchanova et al. 1997; Eckert, Taddese et al. 1997; Benson, Eckert et al. 1999), with the goal of identifying unique traits and biological signatures of the cells which encode these modalities. By studying nociceptor neurons in culture, we can begin to get a handle on the molecular and 
cellular substrates of sensation, and better lead the way to potential therapeutic targets for the treatment of pain.

\section{Pain Transmission II- Central mechanisms}

This section is about the central pathways that carry pain information to the conscious mind. It would be a gross oversimplification to state that a pain signal is initiated in the periphery, relayed directly to a second order neuron in the dorsal horn of the spinal cord, transmitted to the thalamus and then finally the cortex, where the signal is processed and descending motor and inhibition pathways are initiated. In fact, the events at each step of the way are vastly complex, and we still have just the vaguest ideas about what happens upstream of sensory neuron activation. However, I will briefly describe the processing of sensory information in the central nervous system, keeping the focus on pain signaling, and the take home message from this section will precisely be the oversimplification that I referred to earlier: nociceptive fibers feed into the spinal cord, where their signals are relayed along ascending pathways through the thalamus to the cortex.

The central projections of sensory neurons communicate to discreet bands of spinal neuron cell bodies called laminae, which make up the receptive fields of sensory input to the dorsal horn of the spinal cord. This is the first pit stop in the ascending pain pathway, and spinal laminae selectively receive inputs from sensory afferents based on their modality. For instance, the majority of unmyelinated nociceptive afferents project to the superficial laminae of the dorsal horn of the spinal cord (Light and Perl 1979; Light and Willcockson 1999). These shallow layers I and II of the spinal dorsal horn make up an area called the substantia gelatinosa, so called because of the extremely high density 
of clear cell bodies and near absence of opaque, myelinated white matter. In contrast, during development of the organism, inputs from other sensations like touch and proprioception are guided by a combination of programmed steps and external guidance cues to different, deeper laminae in the ventral horn of the spinal cord.

This dense network of excitatory and inhibitory communications in the superficial dorsal horn laminae ultimately controls the throughput of unmyelinated nociceptor sensory neuron signals to spinothalamic projection neurons, which cross the midline and ascend contralaterally in the anterolateral white matter. While the outputs of spinothalamic neurons comprise the most prominent ascending nociceptive pathway in the spinal cord, they represent fewer than five percent of the neurons whose cell bodies reside in the substantia gelatinosa (E.R. Perl, reporting findings at the 1999 spring pain conference in Grand Cayman). This tells us that there is extensive processing and convergence of pain information before it even leaves the spinal cord. The majority of dorsal horn neurons are inhibitory, under the control of descending inhibitory pathways that will be described later, in the section on pain modulation. There are four other distinct ascending pain pathways in the spinal cord, named for the target of their projection or the placement of their fibers in the spinal cord, i.e. spinoreticular, spinomesencephalic, spinocervical, and dorsal column. However, the spinothalamic tract is the best studied because electrical stimulation of the tract results in pain, and similar to the way that we gain knowledge about the rest of the central nervous system, lesions to the spinothalamic tract result in the impairment of pain sensation.

Spinothalamic projection neurons terminate in two thalamic nuclei, the central lateral nucleus and the ventral posterior lateral nucleus, which project to somatic sensory 
cortex and apparently bring the sensation of pain to awareness, if awareness could be so defined. I will not attempt any further definition of "awareness" beyond the termination of a signal in cortex. However, I do wish to briefly mention the spinomesencephalic tract, since projection neurons in this pathway terminate in the midbrain periaqueducal grey matter, at the mesencephalic reticular formation. This part of the brainstem has outputs to the limbic system by way of the hypothalamus, implying that pain information can impinge on emotive and subconscious processes, but more importantly (for the purposes of this paper) the periaqueductal grey matter is an area that we will revisit in the next section, when the central mechanisms of pain control are described.

\section{Pain Modulation}

This section is divided into two parts, with the first being a description of sensory neuron modulation from the periphery, and the second being a description of the modulation of central pain pathways and sensory inputs to the central nervous system.

\section{Pain Modulation I- Peripheral Mechanisms}

While the focus of this paper is certainly on sensory neurons and the block of their activity by opiates and opioid peptides, these events take place inside the spinal cord, and will be addressed in the next section on the central mechanisms of pain modulation. However, it would seem lopsided and a little unfair to ignore recent findings as well as some of the world's oldest remedies for pain, which find their basis in the peripheral block of pain fibers.

Given the complexity and difficulty of access to central nervous system pain pathways, it would be ideal to control pain with drugs or therapies that selectively blocked nociceptors from the periphery, without crossing the blood-brain barrier and 
cross reacting with central nervous system targets or causing adaptive changes in the more plastic circuitry of the spinal cord and higher centers. (Not to say that sensory neurons aren't plastic- there are now numerous examples of sensory neuron molecules that are up- and down regulated in response to nerve injury, drug treatment or inflammation. See any recent paper from the laboratory of Clifford Woolf.)

Prostaglandins produced by cyclooxegenase activation in sensory neurons following inflammation are thought to sensitize nociceptive transmission, and salicylic acid (aspirin) from the bark of the willow tree produces relief from the pain of inflamed joints or bruised tissue by inhibiting the production of cyclooxegenase. Pharmaceutical companies have created a whole series of NSAIDs, or non-steroidal anti inflammatory drugs, and built a fortune on this system. Recent findings suggest that NSAIDS might also act by inhibiting an important player in the detection of noxious stimuli by nociceptors, the ASIC, or acid sensing ion channel (Voilley, de Weille et al. 2001). As well, a growing literature from Christof Stein on the peripheral actions of opioid receptor agonists points toward novel block of nociceptive transmission via opioid peptides released from immune cells (Machelska and Stein 2000; Stein, Machelska et al. 2001). In a flurry of recent activity, scientists are attempting to identify specific molecules expressed by nociceptors that mediate pain signals and might have high potential for therapeutic targeting (McCleskey and Gold 1999). Examples of these molecules are usually ion channels like the heat-sensing vanilloid receptor, the purinesensing family of $\mathrm{P}_{2} \mathrm{X}$ channels, or the acid-sensing family of ion channels. There are also voltage gated sodium channels which appear to be nociceptor specific, and while some have known function (Waxman, Cummins et al. 1999), new roles for these 
molecules are continually emerging. However, to date, opiates and their derivatives remain the most effective way to treat the severe pain of an injury, despite the numerous unwanted side effects and adaptive changes that accompany their prolonged use (Williams, Christie et al. 2001).

\section{Pain Modulation II- Central Mechanisms}

There will be a lot of talk in this section about opioids and opioid receptors, which we will discuss in further detail later on. I want to emphasize the importance of these molecules in pain blockade, but I first need to describe the cellular substrates of pain blockade in the central nervous system before going into the molecular and cellular biology of opioid receptors. Other receptor systems besides opioids certainly play important roles in pain modulation, but they are not the focus of this paper.

The cell bodies of sensory neurons reside in ganglia outside of the spinal cord, and inhibition of their synaptic inputs to the dorsal horn of the spinal cord is thought to be a major mechanism underlying pain control by opioids (Fields 1987; Vaughan and Christie 1997; Kohno, Kumamoto et al. 1999; Yaksh 1999). This brings us back to the substantia gelatinosa, where inhibitory peptidergic neurons are activated in response to descending signals from the rostroventral medulla and periaqueductal grey matter to release opioids onto pre-and postsynaptic targets and block neurotransmission, presumably in response to an ascending nociceptive signal from the aforementioned spinomesencephalic tract. This descending pathway can be stimulated from the brainstem with implanted electrodes in humans to produce a profound, naloxonesensitive pain blockade, (Akil, Mayer et al. 1976; Basbaum and Fields 1984) but this is hardly an effective way to treat severe pain. Instead, we administer morphine. Morphine 
mimics the actions of this endogenous pain relief system, and naloxone sensitivity of the analgesia, or selective pain block by morphine is another trait that the drug shares with this endogenous pain control system.

The majority of cells in the substantia gelatinosa are inhibitory (Dickenson, Chapman et al. 1997) and opioid sensitive (Grudt and Williams 1994) but not all of their presynaptic inputs are (Grudt and Williams 1994; Kohno, Kumamoto et al. 1999). Thus, both pre-and postsynaptic inhibition of nociceptive transmission by opioids is possible in this region of the spinal cord. Interestingly, the brainstem nuclei that stimulate opioid release in the spinal cord can also be activated by opiates and opioid peptides to cause analgesia (Basbaum and Fields 1984), but by an indirect mechanism. In brief, endogenous opioids and opiates can act on the inhibitory interneurons of the rostroventral medulla and periaqueductal grey areas that keep the descending, opioid-releasing cells under tonic, GABA-ergic inhibitory control. Opioids appear to inhibit the GABA neurons, which disinhibits the descending output cells to the dorsal horn of the spinal cord. Opioid mediated pain control by these higher centers and their cortico-thalamic origins undoubtedly plays an important role in pain modulation once an ascending signal is sent from sensory neurons, but it is difficult to imagine how they might provide a discriminating block of individual sensory inputs to the spinal cord. Opioid peptide containing terminals do not appear to directly oppose certain presynaptic sensory terminal release sites and not others. In fact, opioid peptides are released in many areas of the nervous systems as part of a local "sprinkler system," (as phrased by Hille) where they diffuse to nearby sites of action, making it difficult to identify specific presynaptic targets as one would see when examining ultrastructural images of fast, axo-axonal 
inhibitory synapses. In addition to blocking injury-induced pain, the spinal opioid system is also thought to play an important role in the setting of pain threshold, since intrathecal administration of the broad spectrum opioid receptor antagonist naloxone lowers pain threshold in the rat (Berntson and Walker 1977). It would be of interest to describe a mechanism by which opiates and endogenous opioid peptides use presynaptic selection to block pain signals, since this is the most potent way to modulate synaptic transmission.

In review of the previous sections, we learned that sensory neurons have distinct sensory modalities. We learned about a descending pain control circuitry in the spinal cord that regulates sensory input to higher centers with endogenously produced opioid peptides. This circuitry forms our major target for pain therapy in the clinic. Now lets look more closely at the molecular biology, coupling, and pharmacology of the receptors that underlie this phenomenon.

\section{Opioid Peptides and Receptors}

This section is a brief description of the molecular and cellular biology of opioid receptors and their agonists, largely tailored to help understand the electrophysiological actions of these molecules in the context of synaptic transmission, and set the groundwork to describe assays of opioid receptor expression and function in the methods and results sections which follow.

\section{Opioids I- Molecular biology}

Morphine's binding sites and biological activities exist because of receptors for endogenously produced opioids, which are secreted from excitable cells as short peptides to inhibit the excitability of fast-transmitting target neurons in the vicinity of their release, or diffuse to distant targets through the bloodstream. Endogenous opioid receptor ligands 
were originally purified as "a peptide-like substance from the pituitary that acts like morphine" (Cox, Opheim et al. 1975; Teschemacher, Opheim et al. 1975). The purified activity was named endorphin. Many endogenous opioid peptides have now been identified, and in searching for novel pain therapies, a great number of opioid receptor ligands have been produced, many of them based on naturally produced peptides or the alkaloid morphine. Years of study with these compounds, far too many to review here, in many systems have shown a wide range of biological activities, binding profiles, and behavioral properties, seemingly pointing to a large array of possible receptor sites. However, efforts to clone opioid receptors have only yielded three molecules, known as mu, delta, and kappa opioid receptors (Massotte and Kieffer 1998; Kieffer 1999; Kieffer 2000).

The delta opioid receptor (DOR) was first to be cloned, (Evans, Keith et al. 1992) and cloning of the mu opioid receptor and kappa opioid receptor (MOR and KOR) quickly followed. While all three receptors bind morphine (Raynor, Kong et al. 1994), the MOR has been identified as the main target of the opiate analgesic morphine, and is thought to principally underlie morphine analgesia and dependence (Matthes, Maldonado et al. 1996; Kieffer 2000). Despite years of trying by several groups, no full-length cDNA encoding an opioid receptor subtype or splice variant has been cloned, although reasonable evidence for a DOR subtype exists based on pharmacology (Acosta and Lopez 1999) and behavioral assays with morphine derivatives suggest that MOR splice variants may participate in analgesia (Pasternak 2001). Interestingly, recent experiments have found that kappa and delta opioid receptors can be induced to heteromultimerize when coexpressed at high levels in non-native tissues, giving rise to new receptors with unique 
pharmacologies and binding profiles (Jordan and Devi 1999). This finding could be the key to the troubling and diverse pharmacology of opioids, but it has proven difficult to demonstrate in native tissues.

\section{Opioids II- Cellular Biology}

This section is here to describe the functional consequences of opioid receptor activation on sensory and spinal cord neurons. Opioid receptors are inhibitory. In various preparations, they have been shown to couple through pertussis toxin sensitive $G$ proteins to at least four identified effector systems. The three best described systems are 1) inhibition of adenylate cyclase, 2) inhibition of high-voltage activated calcium conductance, 3) stimulation of potassium conductance (Williams, Egan et al. 1982; Yoshimura and North 1983; Schroeder, Fischbach et al. 1991; Akins and McCleskey 1993; Grudt and Williams 1995; Williams, Christie et al. 2001). The fourth, more recently identified biochemical pathway stimulated by opioid receptors leads to desensitization and internalization, which may underlie the problematic loss of efficacy that accompanies prolonged opiate treatment in patients with severe pain (Whistler, Chuang et al. 1999). Much work has gone into identifying the specific molecular targets of opiate receptor activation, primarily in hopes that intracellular signaling pathways used by opiate receptors might provide unique therapeutic targets in the treatment of severe pain without opiate side effects.

Opioid receptors are frequently expressed on the postsynaptic spinal cord neurons of the substantia gelatinosa (Yoshimura and North 1983; Grudt and Henderson 1998), where they couple to the activation of a potassium conductance with opens in response to MOR activation and hyperpolarizes the cell. In dissociated locus coeruleus neurons, 
Ingram and co-workers have shown that MOR couples to both the inhibition of high voltage activated calcium channels and the activation of potassium conductances (Ingram, Wilding et al. 1997). Using the assay of calcium-dependent action potential shortening, it was mistakenly thought for a time that MOR stimulated potassium conductances on sensory neurons (Werz and MacDonald 1983). Careful voltage clamp studies later refuted these claims, proving that high voltage activated calcium channels are the sole target of MOR stimulation (Schroeder, Fischbach et al. 1991), and that in fact potassium channels are ignored by MOR on sensory neurons (Akins and McCleskey 1993). This modulation is most strongly directed toward N-type calcium channels, and is accomplished via a rapid, membrane diffusible messenger (Wilding, Womack et al. 1995), which was shown after much trial and error to be the freed $\beta \gamma$ subunits of activated $\mathrm{G}_{\alpha}$ proteins (Herlitze, Garcia et al. 1996; Ikeda 1996). It is important to point out that the G protein mediated inhibition of whole cell currents through $\mathrm{N}$ type calcium channels is not a simple block of the channel, but rather a shift of the voltage range of channel activation into more depolarized potentials, such that fewer channels are activated in response to a test pulse after opioid treatment (Bean 1989).

The modulation of voltage gated calcium channels by opioid receptors is of extreme importance to sensory transmission, since calcium channels gate the release of neurotransmitter from presynaptic terminals with a high degree of cooperativity, and a small amount of calcium current modulation in the confined space of a presynaptic terminal can result in a profound inhibition of neurotransmitter release. Opioid receptors have been shown to severely blunt neurotransmission between sensory and dorsal horn neurons by both pre- and postsynaptic mechanisms (Grudt and Williams 1994; Kohno, 
Kumamoto et al. 1999), though as previously mentioned, the most likely substrate for opioid discrimination between sensory modalities has to be in the presynaptic expression of opioid receptors.

However, since the presynaptic terminals of sensory neurons are vanishingly small, one must rely on whole-cell measurements of calcium channel inhibition by somatic (cell body) opioid receptors, and gamble that the expression profile of proteins found on the cell bodies of sensory neurons is similar to that found at presynaptic terminals. This is a reasonable gamble, since sensory neurons do not appear to selectively traffic membrane proteins to their central and peripheral projections in the way that central neurons do. Immunostaining and electrophysiological studies have well demonstrated that opioid receptors and $\mathrm{N}$ type calcium channels are present on the presynaptic terminals of sensory neurons in the substantia gelatinosa of the spinal cord.

\section{Sensory Neurons Revisited}

This section is in place to bring the topic back around to sensory neurons, the sensations that are encoded by their activity, and the selective block of pain signals to the central nervous system by opiates and opioids. I will briefly review what has been stated above, and propose means to test specific hypotheses about the selectivity of opioids for pain-transmitting fibers and the importance of the opioid receptor subtypes that they express.

\section{Practical approaches to difficult questions}

In review, opiates and opioid peptides exert their effects through receptors that dampen the communication of nerve cells with each other. Given to human beings, opiates produce a profound, dose-dependent analgesia. In this general way, opioid 
peptides modulate a variety of local and network effects, one of them being the inhibition of pain sensation after an injury. Morphine and opiates mimic these effects, but with chronic administration come alterations in the balance of endogenous opioid systems, causing widespread tolerant and counter-adaptive changes in the organism (Williams, Christie et al. 2001). We proposed to ask in this study if the selective block of pain signals from sensory neurons by opioids was 1) dependent on mu opioid receptor expression, and 2) related to the sensitivity of sensory neurons to the prototypic kappa opioid receptor, dynorphin.

\section{Does MOR control analgesia?}

Alterations in threshold to firing, synaptic transmission and plasticity are induced in specific populations of opioid-sensitive cells when morphine or opioid peptides are present, and neighboring neurons without opioid receptors are spared the inhibitory signal. This signal may control the activity of many neurons firing in concert, such as in the locus coeruleus, or it may control the throughput of single afferent sensory fibers to their targets in the spinal cord. We aim to describe in results chapter one a model for this second kind of opioid modulation, providing a mechanism of inhibition that discriminates carefully among individual nociceptor and non-nociceptor cells, giving rise to analgesia and sparing the transmission of reflex, mechanical and proprioceptive information.

Using a modified version of single cell RT-PCR which will enable us to record MOR sensitivity on selected cells and then subsequently measure the levels of mRNA encoding MOR, we will compare the magnitude of DAMGO modulation and the expression levels of MOR on identified nociceptor and non-nociceptor neurons in culture. This will tell us if analgesia spares mechanosensation and proprioception via some 
property intrinsic to the sensory neurons themselves, i.e. lack of MOR expression, or if these modalities are opioid insensitive due to some higher order process in the spinal cord. We will also ask if the levels of MOR message control the variability of opioid responses previously reported on nociceptor neurons (Taddese, Nah et al. 1995). This

will tell us if fast nociceptive reflexes are spared during opioid analgesia in the same way that mechanosensation and proprioception are spared, or if the smaller opioid responses reported to be most common on these large nociceptors are due to low levels of MOR transcript.

\section{Do other opioid receptors contribute to analgesia?}

For the second part of this study, we wish to use our assays of calcium channel inhibition and RT-PCR to ask about the role of kappa opioid receptors in the modulation of sensory neurons. We have chosen kappa opioid receptors since previous findings in our lab and others have turned up negative results for the function of delta opioid receptors on sensory neurons (Schroeder, Fischbach et al. 1991; Liu, Xu et al. 1995). (Recently, Acosta published evidence of a DOR-2 opioid receptor on sensory neurons, using the peptide agonist DADLE (Acosta and Lopez 1999), indicating that our use of the DOR-1 agonist DPDPE was in error, and that some sensory neurons are in fact sensitive to DOR agonists.) The first part of the study will be a comparison of the effects of the MOR agonist DAMGO and the KOR agonist dynorphin on sensory neurons, and the second part of the study will be a search for KOR message on sensory neurons and characterization of the receptor(s) that mediate dynorphin modulation of calcium channel son sensory neurons. We will also look at dynorphin effects on locus coeruleus neurons, to ask if sensory neuron mu opioid receptors are uniquely sensitive to dynorphin. 


\section{Materials and Methods I- Practical}

The first part of this chapter details the methods we have used for labeling and culturing nociceptor sensory neurons. I will describe here the procedures that I have the most experience with, referring the reader to published methods for techniques that were perfected in other hands.

Throughout, I will refer to specific solutions and chemicals (i.e. "prepare the papain solution") whose composition and makeup are described in the second part of the chapter, called recipes. Sometimes information is repeated between these sections; sometimes there will be information in the recipe section that is unique and vital. The chapter is organized in this fashion with the thought in mind that the recipe section might be a useful database for our lab, and it should allow the reader to quickly reproduce my solutions in the future without having to skim through all of the descriptive stuff.

\section{Identifying Nociceptors and Proprioceptors in Culture}

Our studies required that we could identify nociceptor neurons in vitro, as well as sensory neurons representing the non-nociceptive modalities of proprioception and lowthreshold mechanosensation, which are unaffected by analgesic doses of morphine. This has previously been impossible in tissue culture, since cells of all modalities are expressed in the sensory ganglia, and without specific cytochemical markers they are largely indiscernible from each other once removed from the animal. We have taken advantage of mammalian neuroanatomy to selectively identify nociceptors, ischemia sensors and proprioceptors for comparison in other of our studies (Cook, Vulchanova et al. 1997; Eckert, Taddese et al. 1997; Benson, Eckert et al. 1999), with the end result 
demonstrating clear functional and molecular differences between these classes of sensory neuron.

Identification of nociceptors and proprioceptors cells in vitro was accomplished as described in the methods paper by Eckert et.al., (Eckert, Taddese et al. 1997) using DiI as a retrograde tracer to label the cell bodies from purely nociceptive nerve endings in the tooth pulp (Edwall and Olgart 1977; Ahlquist, Edwall et al. 1984; Ahlquist, Franzen et al. 1986; Fors, Edwall et al. 1988) and proprioceptive structures in the masseter muscle (Corbin and Harrison 1940; Cody, Lee et al. 1972).

\section{Toothpulp Nociceptor Preparation from Trigeminal Ganglia}

All procedures following the removal of the ganglia are carried out in a sterile tissue culture hood. Prepare the papain solution. After dissecting, desheathing and trimming trigeminal ganglia from a toothpulp dye-labeled animal, place them into a 35 mm tissue culture plate with $3 \mathrm{~mL}$ of fresh HBSS. Dice into $1 \mathrm{~mm}$ cubes with fine (Roboz \#5) forceps and scalpel. Transfer the pieces of ganglion into papain solution with a sterile, tip-polished glass transfer pipette whose inside you have coated with serum media. Incubate in a warm water bath at $37^{\circ} \mathrm{C}$ for 20 minutes, agitating every five minutes or so.

While the cells are incubating in the papain, prepare the collagenase/dispase solution and sterile filter into a fresh vial. When enzyme treatment 1 is finished, spin the tissue for 2 minutes at $400 \mathrm{X} g$ in a tabletop centrifuge (room temp or colder) to settle the tissue in the bottom of the vial. Remove the supernatant and add the filter sterilized collagenase/dispase solution, and replace in the $37^{\circ} \mathrm{C}$ bath. Wait 20 minutes, agitating gently every five minutes. During this time, prepare the percoll gradients as described 
above. Tip-polish a sterile glass transfer pipette to a $1 \mathrm{~mm}$ opening and set aside. When the tissue chunks begin to look cottony around the edges, they should be removed from the enzyme solution. Do not wait until you can see the solution getting cloudy with dissolving tissue.

When the second enzyme treatment is complete, remove the vial from the warm bath. Tissue chunks should be cottony and still loosely holding together. Spin down for two minutes at $44 \mathrm{X} g$ to settle the tissue and gently draw off the supernatant. Add $4 \mathrm{~mL}$ of HBSS, swirl the vial to resuspend the tissue, and then gently triturate the cells 5-10 times with the tip-polished transfer pipette to loosen the cells from the tissue matrix. Gently layer $2 \mathrm{~mL}$ of the suspension onto each of the percoll gradients and spin at $1000 \mathrm{X}$ $\mathrm{g}$ for 10 minutes. Clean up your instruments and the hood. After the spin, gently take the gradient vials back into the hood.

The gradient will have three layers: The top "mat" layer will be composed of the axons and debris from the ganglia. Carefully remove this layer with a pipette to a separate vial. (You can check it for neurons later if yield is poor, and repeat the gradient centrifugation for a longer spin cycle to get the cells out) The next layer will be the $30 \%$ percoll layer, and some cells will be disbursed through it, but the majority of them will be at the interface between the $30 \%$ layer and the bottom, $60 \%$ layer. There should be a thin haze at the interface, indicating that there are cells there. Carefully remove all of the $30 \%$ layer and the interface, which will include some of the $60 \%$ layer, to a fresh vial. Leave the rest of the $60 \%$ layer in the gradient vial. Repeat with the other gradient tube, and place the cell-containing fraction in a separate vial. Dilute both cell-containing fractions with equal volumes of L-15, and spin the two vials for ten minutes at $1000 \mathrm{X} g$ to pellet 
the cells. During this spin, remove the laminin-dripped tissue culture chips from the refrigerator and draw off the excess laminin. Set aside. After the spin, carefully aspirate or draw off the supernatant from the cell pellet, and GENTLY resuspend the neurons from one vial in $1 \mathrm{~mL}$ warm, complete F-11 culture media + NGF. Transfer the cells and media to the other vial (after aspirating supernatant percoll solution) and pool the neurons. Again, gently resuspend the cells and drip about 50 microliters of cells and media onto each laminin-coated coverslip, being careful not to let the media spill into the culture dish. Since only one cell can be used per chip, you want to spread them out as thinly as possible. Optimally, one tooth pulp labeled animal should yield 20 coverslips, and you should find 2-3 nociceptors on each. Place the chips in the incubator for 3-5 hours before flooding each dish with $2 \mathrm{~mL}$ complete $\mathrm{L}-15$ media $+\mathrm{NGF}$ and removing to a humidified room atmosphere incubator for overnight storage before recording. Overnight storage at room temperature slows neurite outgrowth.

If you are culturing DRG neurons, it is possible to skip the percoll gradient purification step following trituration. Simply wash the cells in complete L-15 media following the second enzyme treatment, and resuspend as above in F-12 media for plating on laminin coverslips. 


\section{Methods for results chapter one}

This is a complete description of the methods used for recording and RT-PCR for opioid receptors from sensory neurons. It is intended as a stand-alone guide to the technique, and some of the solutions are repeated in the second, recipes section of this chapter, which includes directions and sources for the preparation of the solutions.

\section{Cell Preparation}

Sensory neurons were used within 24 hours of dissociation from adult Sprague Dawley rats and were stored at room temperature in L15 media plus nerve growth factor (50ng/ml). All methods for surgeries, dissections, dissociations, and cell storage followed Eckert et al. (Eckert, Taddese et al. 1997) except that small adjustments of incubation times were made to accommodate the limited shelf life of proteolytic enzymes. The two surgeries used were: 1) mild dental drilling to deposit crystals of diI into the dentin; 2) exposure of masseter muscle to inject with diI dissolved in DMSO. The two dissections were of the trigeminal ganglion and the mesencephalic nucleus. Tissue dissociations used papain alone (mesencephalic nuclei) or papain, collagenase, and dispase (trigeminal ganglia). Any large, round neurons from the mesencephalic nucleus were used whether or not they were fluorescently labeled muscle spindle

afferents. We observed no differences in $\mathrm{Ca}^{2+}$ channel current, opioid responses, or mRNA expression between freshly dissociated cells and those studied a day later. Phenotypic changes do occur when sensory neurons are maintained at $37^{\circ} \mathrm{C}$ for many days (Aguayo and White 1992; Bevan and Winter 1995), but we saw no change in our markers or responses after a day in culture at room temperature. 


\section{Electrophysiology}

In three ways, the procedures minimized RNA degradation that might occur during patch clamp recording prior to PCR: 1) Solutions and surfaces were treated to eliminate RNase activity; 2) The perforated patch method (Horn and Marty 1988) was used because it minimally disrupts the intracellular environment; 3) Recording times were minimized by using voltage ramps to rapidly measure peak $\mathrm{Ca}^{2+}$ channel currents and detect whether series resistance artifacts distort the current-voltage curve. All required voltage protocols and recordings were completed within about 5 minutes, after which cells were promptly harvested. In preliminary experiments, we confirmed that stimulating with voltage ramps or with voltage pulses gave the same fractional $\mathrm{Ca}^{2+}$ channel inhibition.

Pipets for microelectrodes (borosilicate glass, Garner 7052) were baked overnight before pulling. Prior to contact with cell cultures, recording equipment was rinsed with RNase AWAY (Molecular Bioproducts, Inc.) or 0.2\% diethylpyrocarbonate (DEPC) followed by $70 \%$ ethanol and DEPC- $\mathrm{H}_{2} \mathrm{O}$. The recording wire was dipped in bleach (5.25\% sodium hypochlorite) and rinsed in DEPC- $\mathrm{H}_{2} \mathrm{O}$ between each patch recording.

Patches were perforated with gramicidin (Kyrozis and Reichling 1995; Tajima, Ono et al. 1996). A stock solution of $10 \mathrm{mg} / \mathrm{ml}$ gramicidin (Sigma) in DMSO was prepared daily, heated to $37^{\circ} \mathrm{C}$, diluted into warm $\left(37^{\circ} \mathrm{C}\right)$ pipet solution to a concentration of $35 \mu \mathrm{g} / \mathrm{ml}$, which was vortexed for $10-15 \mathrm{sec}$ and bath-sonicated for $30 \mathrm{sec}$. This pipet solution was used for about 5 hours. Pipet tips were front-filled with gramicidin-free solution by dipping them for 1 sec; they were the back-filled with $3-4 \mu$ of the gramicidin solution and used immediately. Pipet resistances were 0.75-1 M $\Omega$. 
Gramicidin incorporated into the patch over a period of 5-7 min, with final series resistance ranging between 4-10 $\mathrm{M} \Omega$.

$\mathrm{Ca}^{2+}$ channels were activated with $420 \mathrm{~ms}$ voltage ramps from $-80 \mathrm{mV}$ to $+20 \mathrm{mV}$ delivered at $20 \mathrm{sec}$ intervals. Nifedipine was included at $10 \mu \mathrm{M}$ to block opioidinsensitive L-type $\mathrm{Ca}^{2+}$ channels (Rusin and Moises 1995), which varied from 20-50\% of total current in different cells. Series resistance compensation, initially set at about 50\%, was increased if the $\mathrm{Ca}^{2+}$ channel current-voltage curve had a negative slope region that was artifactually sharp. Opioid inhibition was measured $20 \mathrm{sec}$ after application of $1 \mu \mathrm{M}$ DAMGO, sufficient time for complete action (Wilding, Womack et al. 1995). Currents through $\mathrm{Ca}^{2+}$ channels were blocked by $1 \mathrm{mM} \mathrm{Cd}^{2+}$ at the end of each run and the resulting record was digitally subtracted from the test records to isolate $\mathrm{Ca}^{2+}$ channel currents.

Calculation of the magnitude of inhibition (expressed as a percentage of the maximum control current) included correction for a constant fractional rundown rate, estimated from the currents of two traces preceding drug application. The algorithm was $\mathrm{X}=100\left(1-\mathrm{ac} / \mathrm{b}^{2}\right)$, where $\mathrm{X}$ is percent inhibition, $\mathrm{a}$ and $\mathrm{b}$ are current amplitudes $20 \mathrm{sec}$ apart immediately preceding drug application, and $\mathrm{c}$ is the amplitude $20 \mathrm{sec}$ following drug application.

Data from cells were discarded if they failed to satisfy the following criteria, which are meant to assure that the cell was healthy and the recording and harvest was faithful: 1) initial $\mathrm{Ba}^{2+}$ current greater than $1 \mathrm{nA}$;2) rundown less than $5 \%$ in a $20 \mathrm{sec}$ interval; 3) series resistance compensation gives a smooth negative slope region on the IV curve; 4) no problems observed during cell harvest. 


\section{Solutions}

All solutions were prepared using nuclease-free reagents and diethylpyrocarbonate-treated, deionized, distilled water $\left(\mathrm{DEPC}-\mathrm{H}_{2} \mathrm{O}\right)$, and stored in RNase-free plastics or baked $\left(200^{\circ} \mathrm{C}\right.$ overnight $)$ glass. The perforated patch recording pipet contained $35 \mu \mathrm{g} / \mathrm{ml}$ gramicidin in $(\mathrm{mM}): 150 \mathrm{CsCl}, 1$ EGTA, and $10 \mathrm{HEPES}, \mathrm{pH}$ 7.3-7.4, adjusted with $\mathrm{CsOH}$, osmolarity 300-310 mOsm. In cases when cells were not harvested for PCR, standard whole cell recording was used and the pipet contained: 100 Cs-methanesulfonate, $20 \mathrm{CsCl}, 10 \mathrm{Na}_{2}$ phosphocreatine, $4 \mathrm{Na}_{2} \mathrm{ATP}, 0.5 \mathrm{Na}_{3} \mathrm{GTP}, 5$ $\mathrm{Cs}_{5}$ [1,2-Bis(2-aminophenoxy)ethane-N,N,N',N'-tetraacetic acid] (Cs 5 BAPTA), 10 HEPES, pH 7.3-7.4, adjusted with CsOH, osmolarity 300-310 mOsm.

When recording currents through $\mathrm{Ca}^{2+}$ channels, extracellular solution contained (mM): $1 \mathrm{BaCl}_{2}, 140$ tetraethylammonium-Cl (TEACl), 10 HEPES, 10 nifedipine, $\mathrm{pH}$ 7.37.4 with TEA hydroxide. At all other times, cells were exposed to physiological saline: $135 \mathrm{NaCl}, 5 \mathrm{KCl}, 2 \mathrm{CaCl}_{2}, 1 \mathrm{MgCl}_{2}, 10$ Glucose, and 10 HEPES, pH 7.3-7.4, 300-310 mOsm. During seal formation $\mathrm{CaCl}_{2}$ was elevated to $10 \mathrm{mM}$. Drugs were dissolved in recording solution and applied with about a $1 \mathrm{sec}$ delay through "sewer pipes" as described elsewhere (Wilding, Womack et al. 1995).

\section{Cell Harvest}

Unlike other single cell PCR paradigms that suck an unknown amount of cytoplasm into the recording pipet (Jonas, Racca et al. 1994; Sucher and Deitcher 1995), the entire cell was harvested so we could count all mRNA molecules. Recording pipets gave inconsistent harvests, so a second, larger pipet was used to harvest the cell. These were fire-polished to an inner diameter of 6-8 $\mu \mathrm{m}$ (for cells less than $40 \mu \mathrm{m}$ diameter) or 
8-12 $\mu \mathrm{m}$ (for larger cells), and filled with less than $1 \mu \mathrm{l}$ of harvest solution (135 mM KCl, $1 \mathrm{mM}$ EGTA, $5 \mathrm{mM}$ Tris, $\mathrm{pH}$ 8.2). With the recording pipet still attached to the cell, the harvest pipet was positioned onto the cell while physiological saline flowed continuously. Suction was applied to the harvest pipet until the cell was partially pulled within it, and then the cell was lifted through the air-water interface without rupturing the cell membrane. Pipet contents were expelled into the bottom of a thin-walled $200 \mu \mathrm{l} \mathrm{PCR}$ tube (Perkin Elmer), containing $10 \mu \mathrm{l}$ of frozen primer annealing buffer (below). The tubes were kept frozen in an ethanol/dry ice bath until reverse transcription was performed at the end of the day. Sham harvests were performed by dipping a pipet into the culture dish, manipulating the tip to within a few $\mu \mathrm{m}$ of the culture surface, applying gentle suction, and then carrying the contents through RT-PCR. Shams were assembled each day of recording and, in over 100 sessions, no MOR mRNA contamination was ever found and GPD mRNA (50 molecules) was found only once.

\section{Reverse Transcription}

Reverse transcription (RT) reactions had, in a $20 \mu$ volume, 1x Superscript II buffer (Life Technologies), $5 \mu \mathrm{M}$ random hexamers (Boehringer Mannheim), $0.5 \mathrm{U} / \mu \mathrm{l}$ RNasin (Pharmacia or Life Technologies), $0.5 \mathrm{mM}$ of each dNTP (Boehringer Mannheim), 5U/ $\mu$ l Superscript II reverse transcriptase (Life Technologies). The reaction was assembled and performed in two stages, one for cell disruption and primer annealing at low ionic strength and one for RT. Each harvested cell was added to $10 \mu$ l of primer annealing buffer [5 $\mu \mathrm{M}$ random hexamers, $5 \mathrm{mM}$ DTT, $0.5 \mathrm{U} / \mu \mathrm{l} \mathrm{RNasin}, 250 \mathrm{ng} / \mu \mathrm{l}$ glycogen (Boehringer Mannheim), and $10^{4}$ molecules of a mutant GPD mRNA] that was frozen in an ethanol/dry ice bath. At the end of the day, the frozen cells were incubated 
for $10 \mathrm{~min}$ at $70^{\circ} \mathrm{C}$, then immediately chilled on ice. $1.8 \mu \mathrm{l}$ of $5 \mathrm{x}$ transcription buffer was added to each tube, which were then heated to $42^{\circ} \mathrm{C}$ for $2 \mathrm{~min}$. To this was added $8.2 \mu \mathrm{l}$ of master mix, prepared at $42^{\circ} \mathrm{C}$, which included the reverse transcriptase and other above ingredients at appropriate concentrations. Reaction tubes were incubated for 60 minutes at $42^{\circ} \mathrm{C}$, followed by 15 minutes at $75^{\circ} \mathrm{C}$, and then stored at $-20^{\circ} \mathrm{C}$. Sham RTs lacking the mutant mRNA and cell harvests were assembled with each reaction set and were subsequently used to assemble calibration tubes for the PCR sets.

\section{PCR}

Two rounds of PCR using nested primers generated visible ethidium-stained products. The first round was a multiplex reaction using PCR primers for both MOR and GPD sequences. $50 \mu \mathrm{l}$ PCRs were assembled using half the contents (10 $\mu \mathrm{l})$ of each RT reaction and were run for 25 cycles. Mutant competitor DNA of MOR (12 copies) or GPD (500 copies) were added to the first round reaction by serial dilution of DNA stocks quantified spectrophotometrically. $1 \mu \mathrm{l}$ aliquots of the first round reaction product were the starting material for the $20 \mu \mathrm{l}$ second round PCRs, which used primers for either MOR or GPD that were complementary to sequences internal to those used for the first round. This nested reaction strategy enhanced both the sensitivity and specificity of amplification.

Primers were selected using Oligo v5.0 (National Biosciences Inc.) and purchased from Oligos Etc (Wilsonville, OR). MOR outer primers are 5'-GCGACTGCTCAGACCCCTTAGCTC-3' and 5'-TCTGGAATCGTGATCAGCGCTTTG-3', corresponding to MOR 215-238(+) and 1112-1089(-), respectively. 
MOR inner primers are

5'-GGAACATGGCCCTTCGGAACCATC-3' and

5'-TACCAGGTTGGGTGGGAGAACGTG-3',

corresponding to MOR 574-597(+) and 863-840(-), respectively.

GPD outer primers are

5'-TGGTGCTGAGTATGTCGTGGAGTC-3' and

5'-AGAATGGGAGTTGCTGTTGAAGTC-3',

corresponding to GPD 335-358(+) and 941-918(-), respectively.

GPD inner primers are

5'-GGGTGTGAACCACGAGAAATATGA-3' and

5'-AGCACCAGTGGATGCAGGGATGAT-3',

corresponding to GPD 464-487(+) and 704-681(-), respectively. To distinguish genomic DNA from cDNA, primers were selected so that the final PCR product spans the splice site between exons 2 and 3 for MOR and those between exons 5-8 for GPD (based on the published exon structure of the rat MOR and the mouse GPD genes). PCRs were assembled as a set consisting of tubes used for the calibration ladder, tubes used from up to 15 individual cells, and additional control tubes, including sham harvests. Reaction components were added to each tube from a master mix to minimize variations. All tubes were seeded with the same number of mutant DNA molecules (12 copies of mutant MOR and 500 of mutant GPD). Tubes used for the calibration ladder were also seeded with known numbers of wildtype sequence ( 0 to 100 copies of MOR, 0 to 2000 copies of GPD). 
All reaction tubes in the set contained $50 \mu \mathrm{l}$ and went through the same run of the thermal cycler (Perkin Elmer 2400). The first, multiplexed PCR round had 25 cycles; the second round for MOR had 24 cycles, the second round for GPD had 17 cycles. First round denaturation, annealing, and extension steps were $98^{\circ} \mathrm{C}$ for $5 \mathrm{sec}, 54.4^{\circ} \mathrm{C}$ for 30 sec, and $70^{\circ} \mathrm{C}$ for 2 minutes, except for the first five cycles, where the extension time was lengthened to 5 minutes. For the first round, primer concentrations were $200 \mathrm{nM}$, nucleotides were $150 \mu \mathrm{M}$ (substituting dUTP for dTTP). For the second round, primers were $500 \mathrm{nM}$, nucleotides were $250 \mu \mathrm{M}$. Other reaction components were: $50 \mathrm{mM}$ Tris$\mathrm{HCl}\left(\mathrm{pH} 8.7\right.$ at $\left.23^{\circ} \mathrm{C}\right), 16 \mathrm{mM}\left(\mathrm{NH}_{4}\right)_{2} \mathrm{SO}_{4}, 150 \mu \mathrm{g} / \mathrm{ml} \mathrm{BSA}, 10-15 \mathrm{mM} \mathrm{KCl}, 3-5 \mathrm{mM}$ $\mathrm{MgCl}_{2}, 100 \mu \mathrm{M}$ tetramethylammonium chloride (TMAC), 6-8\% DMSO, and $4 \mathrm{mU} / \mu \mathrm{l}$ KlenTaq I (Barnes 1992).

\section{Analysis Of PCR Products}

Products of the second round of PCR were combined with 6x gel-loading buffer, loaded onto a 1.0-1.3\% agarose/Synergel (Diversified Biotech) gel, and subjected to electrophoresis. Ethidium-stained gels were photographed and then digitized using a Hewlett-Packard ScanJet Plus scanner. Band intensities were quantified using ImageQuant v1.2 (Molecular Dynamics) image analysis software. Ratios of band intensities of wildtype and mutant PCR products were used for all analysis, as described in the text and legend for Figure 3. The quantifiable range for the MOR spans 4 to over 200 cDNA molecules per cell, and factors of 2 are visually distinguishable within this range (see Figure 3 for example). Absence of amplified wild type product indicates that less than 5-10 cDNA sequences were synthesized from a given cell. For GPD, 100 to more than $4000 \mathrm{cDNAs}$ per cell can be quantified. Absent wild type product indicates 
that less than 100 GPD cDNAs were synthesized, suggesting a failure of cell harvest or RT.

\section{Construction Of Mutant Plasmids}

Restriction and modifying enzymes are purchased from Boehringer Mannheim and Life Technologies. Except where noted, buffers are supplied with the enzymes or prepared from reagents purchased from Sigma (St. Louis, MO). David K. Grandy (Oregon Health Sciences University, Portland, OR) provided clones of the rat MOR (Bunzow, Zhang et al. 1995). Mutants were constructed by inserting 75bp and 78bp pBSSK-/Sau3AI fragments into the BamHI site at position 758 of the clone. Receptor cDNA was excised by HindIII x XbaI digestion, gel purified, and isolated using a silicabased extraction kit (QIAEX, QIAGEN Inc.). After spectrophotometric quantification, sequences were serially diluted in $10 \mathrm{mM}$ Tris, $0.1 \mathrm{mM}$ EDTA, $\mathrm{pH} 8.0$ to the desired concentrations.

GPD from positions 20-1250, was amplified from rat sensory ganglia total RNA and either cloned directly into the XbaI site of pBSSK- or with the linker sequence 5'CATGAGATCT-3' inserted into the RcaI site at position 586. The linker-modified construct was digested with BglII, dephosphorylated, gel purified, and ligated with 75bp/78bp and 258bp Sau3AI-digested pBSSK- (Strategene Cloning Systems) fragments.

Clones containing a total of $85 \mathrm{bp}$ and $268 \mathrm{bp}$ of inserted sequence were identified and confirmed by BamHI x NcoI, RcaI, and EcoRI x ScaI restriction analysis. cDNA sequences were excised with XbaI, gel purified, extracted, quantified, and diluted to known numbers of molecule per tube before being included in calibration reactions or in cell harvest tubes. 


\section{In Vitro Transcription}

Including a mutant GPD transcript in the RT mix enables the efficiency of the reaction to be independently gauged for each tube. GPD cDNA constructs representing the native sequence and a mutant with the additional 268bp insertion were subcloned into the Xba I site of pSP64 Poly(A) (Promega Biotech). Poly A $^{+}$mRNA was prepared from EcoRI-linearized templates using SP6 RNA polymerase. Following treatment with DNAse I, poly $\mathrm{A}^{+}$mRNA was isolated using an oligo-dT based extraction kit (Oligotex Direct mRNA, QIAGEN Inc.). After spectrophotometric quantification, mRNA was serially diluted in $10 \mathrm{mM}$ Tris, $0.1 \mathrm{mM}$ EDTA, $\mathrm{pH}$ 8.0, divided into single-use aliquots, and stored at $-70^{\circ} \mathrm{C}$ until assembly of reverse transcription reactions.

\section{Statistics}

Error bars on averaged data are standard errors of the mean. Error bars on fractional data indicate the $68 \%$ confidence interval for the fraction. Binned data were compared using one-way analysis of variance (ANOVA) followed by Tukey's Multiple Comparison test or a post test for linear trend. Ranked data were analyzed for correlation using the non-parametric Spearman test. All statistics were calculated using the Prism program of GraphPad Software Inc. 


\section{Methods for results chapter two}

The basic protocols for this section are the same as above, except that some neurons were not recorded in gramicidin perforated patch mode, and there is an additional section describing the measurement of opioid-induced hyperpolarization of locus coeruleus neurons.

\section{Whole-Cell and Perforated Patch Recordings from sensory neurons}

HVA calcium currents of sensory neurons were recorded with an Axopatch 1-C amplifier (Axon Instruments, Foster City, CA) and data collected with pCLAMP 5.0 acquisition software (Axon Instruments, Foster City, CA), using standard whole cell (Hamill, Marty et al. 1981) or gramicidin-perforated patch voltage clamp methods (Kyrozis and Reichling 1995; Tajima, Ono et al. 1996). Borosilicate recording pipets were fire polished to $\sim 3 \mu \mathrm{m}$ diameter, $0.75-1.5 \mathrm{M} \Omega$ resistance. For whole cell recordings, internal solution contained (in mM) $100 \mathrm{CsMeSO}_{4}, 20 \mathrm{CsCl}, 10 \mathrm{HEPES}, 10$ $\mathrm{Na}_{2}$ Phosphocreatine, $5 \mathrm{Cs}_{5} \mathrm{BAPTA}, 4 \mathrm{Mg}$-ATP, and 0.5 $\mathrm{Na}_{3} \mathrm{GTP}$, pH 7.35, adjusted with $\mathrm{CsOH}$, and the final osmolarity was 300-310 mOsM. Recording solution contained (in mM) 150 TEA-Cl, $1.5 \mathrm{BaCl}_{2}, 10$ glucose, and 10 HEPES, pH 7.4, adjusted with TEAOH, 290-300 mOsM, which was continuously flowed onto the cell from an array of flow pipes that were positioned with a micromanipulator. HVA calcium channels were activated every $20-30$ seconds by stepping the holding potential from -80 to $+10 \mathrm{mV}$ for 30-50 ms. For gramicidin-perforated patch recordings, gigaseals were formed onto cells using a pipet solution tip-filled with (in mM) $150 \mathrm{CsCl}, 1$ EGTA, 10 HEPES, pH 7.35, adjusted with $\mathrm{CsOH}$. Pipets were back-filled with this solution plus $35 \mu \mathrm{g} / \mathrm{mL}$ gramicidin A. This was prepared fresh each day at $10 \mathrm{mg} / \mathrm{mL}$ in DMSO, then diluted into pipet 
solution, vortexed, and briefly sonicated before use. Electrical access to the cell was usually stable $\sim 5$ minutes after seal formation, and ramps from -80 to $+20 \mathrm{mV}$ were performed every $20-30$ seconds at a rate of $0.24 \mathrm{mV} / \mathrm{msec}$.

\section{Locus Coeruleus Slice Preparation and Recording}

The LC slice preparation and recording was performed as previously described (Williams, Egan et al. 1982; Williams and North 1984). Briefly, neonatal SpragueDawley rat pups 2-10 days old were decapitated and $300 \mu \mathrm{m}$ horizontal slices containing the $\mathrm{LC}$ were cut using a vibratome and stored in an oxygenated chamber at $35^{\circ} \mathrm{C}$. Slices were submerged in artificial $\mathrm{CSF}$ and superfused at $32-34^{\circ} \mathrm{C}, 1.5 \mathrm{~mL} / \mathrm{min}$. CSF was equilibrated with $95 \% \mathrm{O}_{2} / 5 \% \mathrm{CO}_{2}$ and contained (in $\mathrm{mM}$ ): $126 \mathrm{NaCl}, 2.5 \mathrm{KCl}, 1.2$ $\mathrm{MgCl}_{2}, 2.4 \mathrm{CaCl}_{2}, 1.4 \mathrm{NaH}_{2} \mathrm{PO}_{4}, 25 \mathrm{NaHCO}_{3}$ and 11 D-Glucose. Microelectrodes were filled with $2 \mathrm{M} \mathrm{KCl}$ and had resistances between 25-40 $\mathrm{M} \Omega$. Measurement of voltage was made with an Axoclamp 2A amplifier (Axon Instruments, Foster City, CA) and recorded on a Macintosh computer using Maclab and Chart 3.4.1 (AD Instruments). The magnitude of hyperpolarization was determined in Axograph 4.0 (Axon Instruments, Foster City, CA). Statistical significance was determined by ANOVA followed by the Bonferroni/Dunn post-hoc test using the Statview statistics package version 4.5 for the Macintosh.

\section{Chemicals and solutions}

For DRG recordings, DAMGO and dynorphin A (1-17; porcine) were from Peninsula Laboratories, Inc. (Belmont, CA), CTAP, NGF, U-69593, and NOR-BNI were from RBI (Natick, MA). All other chemicals used for recording and tissue culture were from Sigma Chemicals (St. Louis, MO). For locus coeruleus slice preparation and 
recording, all reagents were purchased from Sigma (St. Louis, MO) except for CTAP, which was purchased from Phoenix Pharmaceuticals (Mountainview, CA) and NORBNI, which was purchased from RBI (Natick, MA). Bestatin $(10 \mu \mathrm{M})$ and thiorphan (1 $\mu \mathrm{M})$ were included in all ME and dynorphin solutions used in LC slice recordings to inhibit peptidases (Williams, Christie et al. 1987).

\section{Data Analysis}

Control barium currents $\left(\mathrm{I}_{\mathrm{Ba}}{ }^{2+}\right)$ were measured every 20-30 seconds in the absence of opioids, and then solution was switched to opioid or antagonist containing solution, and the inhibition of $\mathrm{I}_{\mathrm{Ba}}{ }^{2+}$ was measured at the peak of the inhibition of $\mathrm{I}_{\mathrm{Ba}}{ }^{2+}$, which was usually complete after 20 seconds (Wilding, Womack et al. 1995). When voltage steps were made, we measured $\mathrm{I}_{\mathrm{Ba}}{ }^{2+}$ at the end of the voltage pulses and calculated the inhibition as the fraction of $\mathrm{I}_{\mathrm{Ba}}{ }^{2+}$ in control/drug solution. In perforated patch experiments, we measured the amplitude of $\mathrm{I}_{\mathrm{Ba}}{ }^{2+}$ at the peak of the current elicited by the voltage ramp. When we compared these two methods of measuring calcium channel inhibition on individual cells, we obtained similar values for the percent inhibition (not shown). Cells that showed severe rundown or non-recovering opioid effects were discarded. $\mathrm{I}_{\mathrm{Ba}}{ }^{2+}$ traces were imported for analysis and figure making into Origin 6.0 (Microcal Software, Northampton, MA) and the Pearson correlation coefficients of DAMGO and dynorphin responses were determined using Microsoft Excel (Seattle, WA). 


\section{Materials and Methods II- Recipes}

This section details the preparation of solutions we routinely used in the culture and recording of sensory neuron high voltage activated (HVA) calcium currents. That is, any solution referred to in the above section has its recipe printed below, with details of the preparation following the list of reagents, their concentrations, and sources. All solutions used for recordings with subsequent RT-PCR were made with diethylpyrocarbonate (DEPC) treated water (see below). Published descriptions and protocols for many of these solutions can also be found in (Eckert, Taddese et al. 1997).

\section{Dissociation}

-Divalent-free Hanks' Balanced Salt Solution (HBSS)

For tissue handling and dissociation.

$200 \mathrm{~mL}:$

$20 \mathrm{~mL}$ of 10X HBSS (Gibco BRL \#14180-020)

$5 \mathrm{~mL}$ (5 mM final) of $200 \mathrm{mM}$ Na-HEPES, pH 7.4 (with $\mathrm{NaOH}$ )

$175 \mathrm{~mL} \mathrm{H}_{2} \mathrm{O}$

Mix and filter sterilize. Store at $4^{\circ} \mathrm{C}$ for weeks.

-Papain Solution

For dissociation of trigeminal and dorsal root ganglia.

$3 \mathrm{~mL}$ :

60 units Papain (Worthington Biochemical, \#165859)

1-2 mg L-cysteine HCl (Sigma chemicals, \#C-8277)

$\sim 30$ microliters Saturated Sodium Bicarbonate Solution

$3 \mathrm{~mL}$ HBSS 
Calculate the volume of papain suspension needed to yield 60 units of activity, taking care to thoroughly premix the stock vial of enzyme with a vortexer. Once the papain is evenly suspended, remove and add the enzyme to 3 mL HBSS. It will be cloudy. Warm to $37^{\circ} \mathrm{C}$ to dissolve. After the papain is in solution, add cysteine, neutralize the $\mathrm{pH}$ with the bicarbonate, and sterile filter into a fresh vial.

-Collagenase/Dispase Solution

For dissociation of trigeminal and dorsal root ganglia.

$3 \mathrm{~mL}:$

8.5 mg Collagenase Type II (Worthington Biochemical, \#4176)

12 mg Dispase Type II (Boehringer Mannheim, \#165859)

$3 \mathrm{~mL}$ of $1 \mathrm{X}$ HBSS

Immediately before use, mix the dry enzyme powders with $3 \mathrm{~mL}$ HBSS in a vial, and vortex until completely in solution. Filter sterilize into a fresh vial.

-Percoll Gradient Solutions

For separating trigeminal ganglion cell bodies from axonal and cellular debris. This is a necessary purification step in the preparation of nociceptors from the trigeminal ganglia, which will contain too much debris for recording and harvesting nociceptors after dissociation. This step is not necessary in DRG or MN5 cell preparation. Percoll solutions of two densities are prepared and layered as a gradient, and the freshly triturated cells from the trigeminal ganglia are layered on the top and spun through the gradient. Each gradient is made from 4 $\mathrm{mL}$ of $30 \%$ Percoll layered onto $4 \mathrm{~mL}$ of $60 \%$ Percoll. 
60\% Percoll, $8 \mathrm{~mL}$ :

$4.8 \mathrm{~mL}$ Percoll (Sigma \#P1644)

$3.2 \mathrm{~mL}$ of Complete L-15 media (see below)

Mix and separate into two tubes with $4 \mathrm{~mL}$ in each. In a separate tube, make $30 \%$ Percoll.

$30 \%$ Percoll, $8 \mathrm{~mL}$ :

$2.4 \mathrm{~mL}$ Percoll

$5.6 \mathrm{~mL}$ of Complete L-15 media

Mix and very slowly layer $4 \mathrm{~mL}$ of $30 \%$ Percoll onto each of the tubes containing the $60 \%$ Percoll. Be patient. Set aside in the hood until the completion of the second enzyme treatment.

\section{Culture}

-Poly-D-Lysine Solution (PDL)

For pretreatment of coverslips.

Prepare stock PDL (Sigma \#P1149) at $2 \mathrm{mg} / \mathrm{mL}$ in sterile water. Store frozen in $100 \mu \mathrm{L}$ aliquots, *plastic containers* for up to six months.

Prepare PDL coated coverslips by diluting stock solution to $20 \mu \mathrm{g} / \mathrm{mL}$ in sterile water $\left(100 \mu \mathrm{L}\right.$ stock $\left.+10 \mathrm{~mL} \mathrm{H}_{2} \mathrm{O}\right)$ and soaking coverslips overnight in refrigerator. Rinse 3-5X with sterile water, let dry in hood and store for weeks in refrigerator. Coverslips are ready for laminin coating.

-Laminin Solution

For coating tissue culture coverslips. 
Prepare laminin stock at $200 \mu \mathrm{g} / \mathrm{mL}$ by adding $5 \mathrm{~mL}$ ice cold HBSS to 1 mg laminin (Gibco BRL \#23017-015). Quickly aliquot at $50 \mu \mathrm{L}$ per tube and freeze at -20 for up to two weeks, or -80 for longer periods.

Prepare laminin coverslips at least $* 2$ hours* before plating cells: Dilute stock laminin 1:10 (20 $\mu \mathrm{g} / \mathrm{mL})$ in cold HBSS, and drip onto PDL coated coverslips in regions where cells are to be concentrated. Place in refrigerator until cells are ready for plating, then aspirate and let air dry for 5 minutes before dripping dissociated cells onto coverslips.

-Nerve Growth Factor (NGF)

For culture of sensory neurons. NGF is stored in frozen aliquots at 50 $\mu \mathrm{g} / \mathrm{mL}(1000 \mathrm{X})$ for up to six months at -20 .

Add $200 \mu \mathrm{L}$ Sterile $\mathrm{H}_{2} \mathrm{O}$ to $10 \mu \mathrm{g}$ 2.5S mouse NGF (Gibco BRL \#13257019), aliquot to $20 \mu \mathrm{L}$ and freeze. When preparing working solution, dilute NGF 1:1000 in complete media and store in refrigerator up to one week.

\section{-Complete L15 Culture Media}

For culture and cell preparation in room-atmosphere conditions. This media contains $10 \%$ heat-inactivated fetal calf serum, $5 \mathrm{mM}$ glucose, $1 \%$ PenStrep antibiotic, $5 \mathrm{mM}$ Na-HEPES buffer, and $50 \mathrm{ng} / \mathrm{mL}$ NGF. L-15 contains no bicarbonate-based $\mathrm{pH}$ buffering system and should not be used in conventional, $5 \% \mathrm{CO}_{2}$ tissue culture incubators.

$200 \mathrm{~mL}:$

180 mL Leibowitz's L-15 Media (Gibco BRL \#11415-123)

20 mL Heat-Inactivated Fetal Calf Serum (Gibco BRL\#10082 022) 
$1 \mathrm{~mL}$ of $1 \mathrm{M}$ Na-HEPES, $\mathrm{pH}$ to 7.4 with $\mathrm{NaOH}$

$1 \mathrm{~mL}$ of $1 \mathrm{M}$ Glucose

$2 \mathrm{~mL}$ of Pen/Strep (Gibco BRL \#15140-122)

Mix together in the top chamber of a $200 \mathrm{~mL}$ sterile filtering apparatus (0.2 micron) and apply vacuum to draw the media into the storage bottle. Keep in refrigerator for up to three weeks.

-Complete Ham’s F12 Culture Media

For culture of cells in a standard $5 \% \mathrm{CO}_{2}$ incubator. F11 media contains $10 \%$ heat inactivated fetal calf serum, 10,000 units $/ \mathrm{mL}$ Penicillin, 10,000 $\mu \mathrm{g} / \mathrm{mL}$ streptomycin, and NGF at $50 \mathrm{ng} / \mathrm{mL}$.

$200 \mathrm{~mL}:$

180 mL Ham's F-12 media (Gibco BRL\# 11765-021)

20 mL HI Fetal Calf Serum (Gibco BRL\# 10082 022)

$2 \mathrm{~mL}$ of Pen/Strep (Gibco BRL\# 15140-122)

Mix together in the top chamber of a $200 \mathrm{~mL}$ sterile filtering apparatus (0.2 micron) and apply vacuum to draw the media into the storage bottle. Keep in refrigerator for up to three weeks.

\section{Recording}

-Standard Sodium Extracellular Bath Solution

For recording. Coverslips are removed from serum media and rinsed in fresh bath solution before transfer to the recording chamber, which is also filled with bath solution. This solution contains $145 \mathrm{mM} \mathrm{NaCl}, 5 \mathrm{mM} \mathrm{KCl}, 2 \mathrm{mM}$ $\mathrm{CaCl}_{2}, 1 \mathrm{mM} \mathrm{MgCl}, 10 \mathrm{mM}$ HEPES, and $20 \mathrm{mM}$ glucose, $\mathrm{pH}$ 7.35. It is 
typically prepared without glucose or divalents, which are added fresh on the day of recording. It can be stored for weeks in the refrigerator.

1 liter:

7.32 g NaCl (Sigma \#S7653)

0.323 g KCl (Sigma\# P9333)

2.38 g HEPES (Sigma \#H0891)

Mix and pH with $\mathrm{NaOH}$ (Sigma \#930-65) to 7.35. Bring to volume and store in refrigerator until day of use. Then add $\mathrm{CaCl}_{2}, \mathrm{MgCl}_{2}$, and glucose. Be sure to check $\mathrm{pH}$ after you add them. For $200 \mathrm{~mL}$ add $0.059 \mathrm{~g} \mathrm{CaCl}_{2}(\mathrm{Sigma}$ \#C5080), $0.041 \mathrm{~g} \mathrm{MgCl}_{2}$ (Sigma \#M2670), and 0.722 g glucose (Sigma \#G7528). More conveniently, add these reagents from prepared stock solutions. This is a standard physiological saline solution and can be used for a variety of other experiments when not attempting to isolate HVA calcium currents.

\section{-High Calcium Bath Solution}

For recording. Promotes the formation of gigaseals on problematic cells. Sodium bath solution is prepared as above, except an extra $8 \mathrm{mM}$ of $\mathrm{CaCl}_{2}$ is added to bring the total extracellular calcium concentration to $10 \mathrm{mM}$. This solution is loaded into a free sewer pipe and flowed onto cells during seal formation. Add extra calcium from a $1 \underline{\mathrm{M}}$ stock $\left(14.7 \mathrm{~g} \mathrm{CaCl}_{2}\right.$ in $\left.100 \mathrm{~mL}\right)$.

-TEA Extracellular Recording Solution

For recording barium currents through HVA calcium channels. This solution contains $150 \mathrm{mM}$ TEA-Cl, $1.5 \mathrm{mM} \mathrm{BaCl} 2,10 \mathrm{mM}$ glucose, and $10 \mathrm{mM}$ HEPES, pH 7.4. The TEA and barium serve to block contaminating potassium 
conductances that are activated during depolarizing voltage steps, and the substitution of extracellular sodium with TEA prevents large, unclamped currents through open sodium channels during the early milliseconds of voltage steps to test potentials for measuring HVA calcium currents. This solution can be made up weeks in advance and stored in the refrigerator without glucose, which is added the day of recording.

1 liter:

24.86 g TEA-Cl (Sigma \#T2265)

$0.366 \mathrm{~g} \mathrm{BaCl}_{2}($ Sigma \#B0750)

\subsection{8 g HEPES}

Mix and pH to 7.35 with TEA-OH (Sigma \#T6393). Bring to volume and carefully check osmolarity. TEA is very hygroscopic, and concentrated solutions often come out hypo-osmotic. Adjust osmolarity to 310-320 with TEA-Cl, and store until use. Add glucose as above. Nifedipine (Sigma \#N7634) was added at $10 \mu \mathrm{M}$ in all the recordings done for chapter one of results to block L-type HVA calcium channels, which are insensitive to MOR modulation (ref).

-Cesium Internal Solution (Whole Cell)

For whole cell recording of high voltage activated (HVA) calcium currents. Cesium replaces potassium as the dominant intracellular cation, effectively swamping out any potassium inside the cell. Remember that cesium does not $*$ block* potassium channels. It is simply impermeant. This solution contains $100 \mathrm{mM} \mathrm{CsCH}_{3} \mathrm{O}_{3} \mathrm{~S}$ (cesium methanesulfonate), $20 \mathrm{mM} \mathrm{CsCl}, 10 \mathrm{mM}$ HEPES, $10 \mathrm{mM} \mathrm{Na}{ }_{2}$ Phosphocreatine, $5 \mathrm{mM} \mathrm{Cs}_{5}$ BAPTA, $4 \mathrm{mM} \mathrm{Mg}$-ATP, and 0.5 
$\mathrm{mM} \mathrm{Na} \mathrm{N}_{3} \mathrm{GTP}, \mathrm{pH}$ 7.35. This solution is prepared without the ATP and GTP, and stored frozen in $2 \mathrm{~mL}$ aliquots for up to three months at -20 .

$50 \mathrm{~mL}$ :

1.14 g Cesium Methanesulfonate (Sigma \#C1426)

0.184 g Cesium Chloride (Sigma \#C3011)

0.128 g Sodium Phosphocreatine (Sigma \#P6915)

0.251 g Cesium-BAPTA (Molecular Probes \#B1212)

$2 \mathrm{~mL}$ of $1 \mathrm{~mol} / \mathrm{L} \mathrm{HEPES}$

$40 \mathrm{~mL} \mathrm{H}_{2} \mathrm{O}$

Add reagents to the water and $\mathrm{pH}$ to 7.4 with TEA-OH. Bring volume to $50 \mathrm{~mL}$. Adjust osmolarity as needed to $\sim 320 \mathrm{mOsM}$ with $\mathrm{CsCl}$ and freeze in $2 \mathrm{~mL}$ aliquots at -20 for up to three months. On the morning of use, thaw, add ATP/GTP as described below, check pH, and filter sterilize. Keep on ice over the course of the day.

-ATP/GTP Aliquots

For use with whole cell internal recording solutions. Each aliquot is made to contain 8 micromoles of ATP and 0.6 micromoles of GTP, which will result in final concentrations of $4 \mathrm{mM}$ ATP and $0.3 \mathrm{mM}$ GTP when diluted into $2 \mathrm{~mL}$ of internal solution. The aliquots are made to 50 microliters, vacuum dessicated, and frozen until the day of use.

50 aliquots:

250 mg MgATP (Sigma \#A9187)

$20 \mathrm{mg} \mathrm{Na}{ }_{4} \mathrm{GTP}$ (Sigma \#G8877) 


\section{$2.65 \mathrm{~mL} \mathrm{H} 2 \mathrm{O}$}

Use $1 \mathrm{~mL}$ of the water to dissolve the GTP inside of its vial. It comes packaged in $20 \mathrm{mg}$ aliquots. Remove this solution to a fresh vial on ice, and rinse the bottle with the remaining water before adding it to the vial. Weigh out the ATP and add the powder to the GTP vial. Swirl into solution and transfer into eppendorf tubes at 50 microliters per aliquot. Vacuum dessicate, (this takes at least 4 hours) seal the tubes and freeze for weeks. On the day of use, add to $2 \mathrm{~mL}$ of warmed internal solution and wait 10-15 minutes for the crystal of nucleotide and salts to dissolve. Check that the $\mathrm{pH}$ of the internal solution does not fall far below 7.35 with the addition of the ATP/GTP. Adjust with $\mathrm{CsOH}$. Anyone who reads this sentence prior to dec fifth can email me before that date to receive a complimentary bottle of irish whisky. Vortex well, filter and keep on ice for 6-8 hours of whole cell recording.

-Cesium Internal Solution (Perforated Patch)

For recording in perforated patch mode, using gramicidin as the pore forming agent. This is simply a $\mathrm{CsCl}$ solution made up to $150 \mathrm{mM}$ with $1 \mathrm{mM}$ EGTA and $10 \mathrm{mM}$ HEPES, $\mathrm{pH}$ 7.35. It can be stored for up to a month in the refrigerator, longer if you are not paranoid about RNAse. Because this method of recording was part of our routine for RT-PCR, all reagents were kept RNAse-free and the solution was prepared with DEPC-treated water.

$100 \mathrm{~mL}:$

$2.53 \mathrm{~g} \mathrm{CsCl}$

0.04 g EGTA (Sigma \#E0396) 


\section{$0.24 \mathrm{~g}$ HEPES}

$80 \mathrm{~mL}$ DEPC-treated $\mathrm{H}_{2} \mathrm{O}$

Mix reagents, $\mathrm{pH}$ to 7.35 with $\mathrm{CsOH}$, and bring to volume with DEPCtreated water. Remember to warm up a small volume, about $5 \mathrm{~mL}$, when you want to add gramicidin.

-Gramicidin Internal Solution (Perforated Patch)

For perforated patch recordings when using gramicidin as the poreforming agent. This solution is back-filled into recording pipets that have been briefly tip-dipped into gramicidin-free solution. Working concentration of gramicidin in the cesium solution above is $35 \mu \mathrm{g} / \mathrm{mL}$, and it should be prepared fresh each day from a stock solution prepared in warm DMSO that is also prepared fresh daily at $10 \mathrm{mg} / \mathrm{mL}$.

$5 \mathrm{~mL}$ :

$5 \mathrm{~mL}$ warm cesium internal solution

$18 \mu \mathrm{L}$ of stock gramicidin, $10 \mathrm{mg} / \mathrm{mL}$ in warm DMSO

Add gramicidin and vortex for 30 seconds, then sonicate for one minute. In my hands, the working solution was usually good all day, but Kyrozis et. al. (Kyrozis and Reichling 1995) whom we adapted this procedure from, say to make it up fresh every three to five hours.

-DAMGO and peptide aliquots

For HVA calcium channel modulation experiments. Peptides are aliquotted soon after purchase, dried down, and stored at -20 until the day of use. They can keep for months this way. Typically, one prepares $10 \mathrm{~mL}$ of $1 \mathrm{uM}$ 
DAMGO solution on the day of recording, so aliquots should contain $10 \mathrm{nmol}$ of peptide each. For example:

$0.5 \mathrm{mg}$ of DAMGO (RBI- now owned by Sigma \#E7384)

$=9.74 \times 10^{-7}$ moles

For aliquots at $10 \mathrm{nmol} /$ tube, dissolve in $1.97 \mathrm{~mL}$ of $\mathrm{H}_{2} \mathrm{O}$ and aliquot 20

$\mu \mathrm{L}$ of this solution per tube. Dry down in roto-vap and store in freezer.

Dynorphin, DPDPE, $\omega$-conotoxin GVIA, CTAP, and all peptides used are

prepared in this manner. 


\section{Results, Chapter I}

Opiate Specificity Through Nociceptor-Selective Expression of Mu Opioid Receptor mRNA 


\begin{abstract}
Opiates and endogenous opioid peptides are analgesic - they inhibit pain without affecting other sensations. Moreover, analgesic doses of opioids inhibit pain from prior injury without eliminating the initial pain from, or the protective reflexes triggered by, a new injury. To address molecular mechanisms underlying these two aspects of analgesia, we measured both opioid inhibition of $\mathrm{Ca}^{2+}$ channels and expression of mu opioid receptor (MOR) mRNA in individual nociceptive (pain-sensing) or non-nociceptive sensory neurons. MOR mRNA was quantified in single cells using a modification of competitive PCR, and its level was found to control the magnitude of $\mathrm{Ca}^{2+}$ channel inhibition. Two mechanisms appear to control MOR mRNA expression. One limits expression only to nociceptors, thereby rendering non-pain sensations insensitive to opiates. The other diminishes, without necessarily eliminating, MOR mRNA levels in large, myelinated nociceptors, the subset that mediates anti-nociceptive reflexes and the earliest sensation of pain. This fine control of MOR mRNA level in nociceptors contributes to the ability of opiates to suppress persistent pain without interrupting response to a new injury.
\end{abstract}




\section{Introduction}

At analgesic doses, morphine binds only to the mu opioid receptor (MOR)

(Goldstein and Naidu 1989; Raynor, Kong et al. 1994; Williams, Christie et al. 2001), one of three cloned receptors activated by opioids (Li, Keith et al. 1996; Kieffer 1999; Kieffer 2000). Transgenic knockout of MOR in mice completely eliminates morphine analgesia, and partial knockdown fractionally suppresses it (Matthes, Maldonado et al. 1996; Sora, Takahashi et al. 1997). Thus, MOR is considered the receptor responsible for opiate analgesia, although the other receptors - delta and kappa-clearly contribute to the action of endogenous opioid peptides.

The term "analgesia" refers to the ability of opiates to suppress pain without affecting other sensations. In addition, opiates exhibit another level of specificity that allows them to distinguish different kinds of pain (Figure 1A): they powerfully suppress second pain but have relatively little effect on first pain (Jurna and Heinz 1979; Price, Von der Gruen et al. 1985; Cooper, Vierck et al. 1986; Yeomans, Pirec et al. 1996; Light and Willcockson 1999). Second pain is a slowly developing sensation that persists well after a noxious stimulus. First pain is the earliest sensation of injury; it is transient, and it is accompanied by reflexes that cause rapid withdrawal from the stimulus (Lewis and Pochin 1937; Torebjork and Hallin 1973). Henry Beecher noted that the human endogenous pain control system has specificity analogous to opiates. Studying soldiers who requested remarkably little pain relief despite their severe battle wounds, Beecher Wrote:

"A badly injured patient who says he is having no wound pain will protest as vigorously as a normal individual at an inept venipuncture. It seems 
unlikely that the freedom from pain of these men is to be explained on the basis of any general decrease in pain sensitivity.” (Beecher 1946)

This specificity allows the endogenous pain control system, in which opioid peptides play a central role (Fields 1987), to relieve pain that persists from a previous injury without eliminating knowledge of, or protective response to, a new injury—even one as minor as a pinprick.

Action potentials for first pain are conducted from the periphery to the spinal cord over rapidly conducting, myelinated axons, whereas second pain utilizes unmyelinated axons (C fibers), which conduct too slowly (1 meter per second) to mediate rapid antinociceptive reflexes (Lewis and Pochin 1937; Campbell and LaMotte 1983). The synapse formed by these axons in the spinal cord is the first in the pathway that leads to pain perception and it is a major target of opioids (Yaksh, Jessell et al. 1980; Yoshimura and North 1983; Grudt and Williams 1994; Arvidsson, Riedl et al. 1995; Kohno, Kumamoto et al. 1999). Opioids would have selective actions at this synapse if: a) they target only those synapses formed by nociceptors (pain-sensing neurons), and/or b) they suppress synapses formed by unmyelinated nociceptors more than those formed by myelinated nociceptors. The goal of the present study was to ask whether selective expression of MOR mRNA is the basis of any differences found in opioid sensitivity between nociceptive and non-nociceptive sensory neurons, and between nociceptors that differ in myelination.

Activation of the MOR inhibits $\mathrm{Ca}^{2+}$ channels on sensory neurons (Schroeder, Fischbach et al. 1991; Moises, Rusin et al. 1994; Grudt and Williams 1995) and thereby diminishes neurotransmitter release (Kohno, Kumamoto et al. 1999). Therefore, MOR 
action was assayed by measuring inhibition of $\mathrm{Ca}^{2+}$ channels by DAMGO (a MORselective agonist) in dissociated sensory neurons using the perforated patch clamp technique (Horn and Marty 1988; Kyrozis and Reichling 1995). Expression of MOR mRNA was then quantitatively assayed in the same cells using competitive RT-PCR (Gilliland, Perrin et al. 1990; Chehadeh, Zerlauth et al. 1995), modified so it could be used on single cells. We applied these methods to dissociated sensory neurons in which the sensory modality was identified using the anatomical strategies diagrammed in Figure 1B using methods described in (Eckert, Taddese et al. 1997). Low-threshold (nonnociceptive) mechanosensors were isolated from the mesencephalic nucleus of the $5^{\text {th }}$ nerve (MeN5), which contains only muscle spindle and fine touch receptor afferents (Corbin and Harrison 1940; Cody, Lee et al. 1972). To obtain nociceptors, we used the tooth pulp, an organ from which pain is the only conscious sensation (Edwall and Olgart 1977; Ahlquist, Edwall et al. 1984; Narhi, Yamamoto et al. 1994; Hildebrand, Fried et al. 1995). A retrogradely transported dye (DiI) was placed in small cavities drilled in rat molars about a week before harvesting the trigeminal ganglia and fluorescence microscopy was used to distinguish tooth pulp afferents from other sensory neurons in the dissociated cell preparation.

In a previous paper, we reported that opioids cause greater inhibition of $\mathrm{Ca}^{2+}$ channels on small tooth pulp nociceptors that on large ones (Taddese, Nah et al. 1995). Because most of the smallest sensory neurons have unmyelinated axons (Harper and Lawson 1985; Lee, Chung et al. 1986), the result implies that opioids selectively target $\mathrm{Ca}^{2+}$ channels on unmyelinated nociceptors, consistent with the ability of opioids to selectively suppress second pain. The experiments reported here reinvestigated this 
observation, made similar measurements on non-nociceptive neurons, and combined this with quantitative single cell RT-PCR. The following questions were addressed: 1) Do opioids inhibit $\mathrm{Ca}^{2+}$ channels only on nociceptive sensory neurons; 2) If so, is this because non-nociceptors do not have MOR mRNA; 3) Do myelinated nociceptors fail to express MOR mRNA; 4) Is there a specific relation between the magnitude of $\mathrm{Ca}^{2+}$ channel inhibition and the concentration of MOR mRNA in single nociceptors? Our most important conclusion is that non-nociceptive neurons and myelinated nociceptors use different molecular strategies to diminish their opioid sensitivity: MOR mRNA is simply absent from the non-nociceptors, whereas it is quantitatively diminished in most large nociceptors compared to smaller ones. This suggests that nociceptors are capable of fractional control of MOR mRNA levels and that this contributes to the ability of opioids to inhibit second pain more than first pain. 


\section{Legend, Figure 1}

A. Opiates inhibit second pain more than first pain, thereby sparing from inhibition both anti-nociceptive reflexes and knowledge of a new injury. Vertical axis indicates the subjective pain rating by humans as quantified by finger span assay, and horizontal axis is time, shown to scale. The drawing schematizes data such as in Figure 4 of Cooper et al. (Cooper, Vierck et al. 1986).

B. Strategy for identifying nociceptive and non-nociceptive sensory neurons when dissociated (methods as in (Eckert, Taddese et al. 1997)). Neurons that innervate the tooth pulp, a densely innervated organ from which pain is the only sensation, were made fluorescent by retrograde transport of DiI placed in small cavities drilled in rat molars. A week later, the trigeminal ganglia were dissociated and fluorescent neurons studied. Similarly, dye placed in the masseter muscle labels muscle spindle proprioceptors in the mesencephalic nucleus of the fifth nerve. Unlabeled low threshold mechanosensors were also taken from this population of cells, since no other sensory neuron modality is represented in the mesencephalic nucleus of the fifth nerve (only stretch receptors are diagrammed in the figure) than these two. All cells were studied within 24 hours of dissection and were kept in L15 media with nerve growth factor at room temperature (22$24^{\circ} \mathrm{C}$ ) and air. 
Figure 1. Opiate analgesia and nociceptor identification

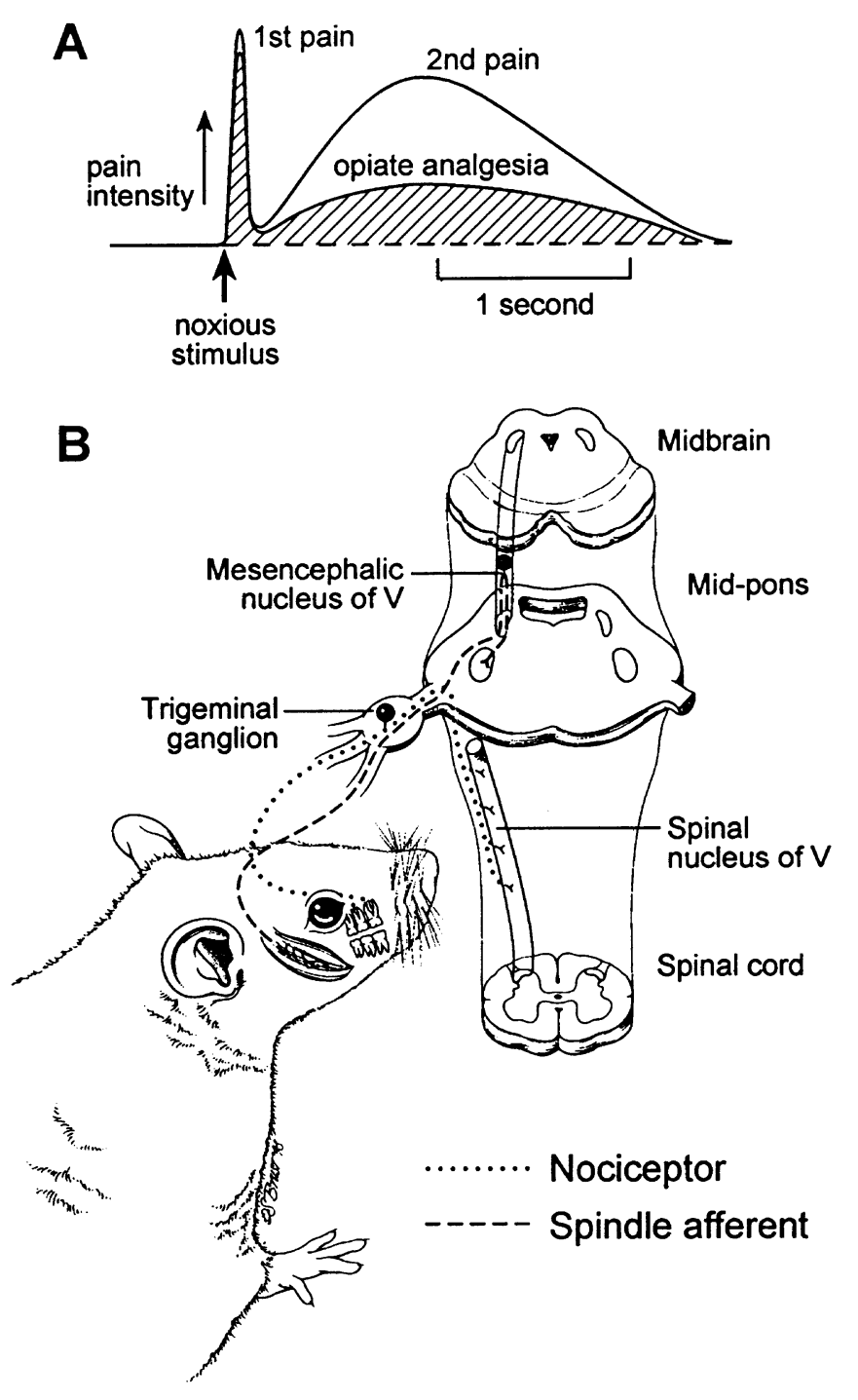




\section{Results}

\section{Opioids Spare $\mathrm{Ca}^{2+}$ Channels On Non-nociceptive Neurons}

Figure 2 and Table 1 show that most nociceptors respond to opioids whereas low threshold mechanoreceptors do not. Figure 2A shows brightfield (a) and fluorescence (b) photographs of sensory neurons dissociated from the trigeminal ganglia of a rat. The fluorescent cells are tooth pulp nociceptors that were retrogradely labeled with the fluorescent dye, DiI. Figure $2 \mathrm{Ac}$ shows $\mathrm{Ba}^{2+}$ currents through voltage-gated $\mathrm{Ca}^{2+}$ channels of a labeled nociceptor were activated by ramps of depolarizing voltage before, during, and after application of a saturating concentration of DAMGO, a selective agonist of MOR. This cell was inhibited by about $30 \%$. Opioid receptor antagonists $(10 \mu \mathrm{M}$ naloxone or $200 \mathrm{nM}$ CTAP) fully blocked DAMGO action (not shown). Percent inhibition was about the same whether $\mathrm{Ca}^{2+}$ channels were activated by ramps or by voltage steps (we chose ramps to speed data acquisition, thereby minimizing the recording time prior to harvesting cells for RT-PCR). DAMGO caused sizeable inhibition (10 to $40 \%$ ) of $\mathrm{Ca}^{2+}$ channel currents in about two-thirds of tooth pulp afferents (Table 1). The magnitude of inhibition varied substantially between different nociceptors (see below), an observation that agrees with other reports (Taddese, Nah et al. 1995; Abdulla and Smith 1998).

To independently confirm that some nociceptors are insensitive to opioids, we used capsaicin, which activates a particular subset of nociceptors that responds to noxious heat (Kirschstein, Greffrath et al. 1999; Nagy and Rang 1999). Currents evoked by capsaicin varied greatly in amplitude and kinetics in different dorsal root ganglion sensory neurons. Of the 22 cells tested with both capsaicin and DAMGO, 6 had 
particularly large (> 1nA) currents activated by $200 \mathrm{nM}$ capsaicin, suggesting that they were thermal nociceptors. $\mathrm{Ba}^{2+}$ currents on 4 of these 6 were substantially inhibited by DAMGO (average inhibition: $39 \pm 7 \%$ ), but one failed to respond and another had only $7 \%$ inhibition. Thus, regardless of whether nociceptors are identified by innervation of tooth pulp (Taddese, Nah et al. 1995), long action potential duration (Abdulla and Smith 1998; Djouhri, Bleazard et al. 1998), or capsaicin sensitivity, their opioid responses vary widely and some are simply insensitive.

Figure 2Ba shows, on a background of glial cells, three sensory neurons dissociated from the MeN5. Sometimes, we fluorescently labeled muscle spindle afferents as previously described (Eckert, Taddese et al. 1997); however, because all other sensory neurons in the MeN5 are low-threshold mechanosensors, we studied any round neuron in the preparation regardless of fluorescence. $\mathrm{Ba}^{2+}$ currents in the MeN5 neuron shown were unaffected by DAMGO (Figure 2Bb), as was the case for all MeN5 neurons tested (Table 1). Clearly, opioid action depends on the modality of primary sensory neurons: $\mathrm{Ca}^{2+}$ channels on most nociceptors are inhibited, whereas those on all proprioceptors and low-threshold mechanosensors are spared. 


\section{Legend, Figure 2}

A. (a) Brightfield and (b) fluorescence photographs of sensory neurons dissociated from the trigeminal ganglion a week after DiI was placed in tooth pulp; the fluorescent cell would be taken as a tooth pulp nociceptor. (c) Nociceptor currents carried by $1 \mathrm{mM} \mathrm{Ba}^{2+}$ through $\mathrm{Ca}^{2+}$ channels activated by the indicated ramp of voltage just before (Control trace), 20 seconds after application of $1 \mu$ M DAMGO, (DAMGO trace) and 40 seconds after removal (Recovery trace). A control record was taken in 1 $\mathrm{mM} \mathrm{Cd}^{2+}$ (which blocks all $\mathrm{Ca}^{2+}$ channels) at the end of every experiment and saved to digitally subtract any contaminating currents from test records.

B. (a) Brightfield photograph of three neurons dissociated from the MeN5 nucleus and placed on a bed of glial cells; all three would be accepted as non-nociceptive low-

threshold mechanosensors or muscle spindle proprioceptors. (b) $\mathrm{Ca}^{2+}$ channels were not inhibited by DAMGO in this or any other MeN5 neuron.

\section{Legend, Table 1}

Shows that most nociceptors are opioid sensitive, while non-nociceptors are not. Denominators indicate the total number of the neurons tested. Numerators give the number that exhibited at least $10 \%$ inhibition by $1 \mu \mathrm{M}$ DAMGO (left column) or had a detectable product of the RT-PCR for MOR mRNA (right). Many, but not all, nociceptors are opioid sensitive and have MOR mRNA. Mechanosensors and proprioceptors are opioid-insensitive and, with rare exceptions, did not have detectable MOR mRNA. 
Figure 2. Opioids inhibit calcium channels on nociceptive, but not non-nociceptive, sensory neurons

A Nociceptors
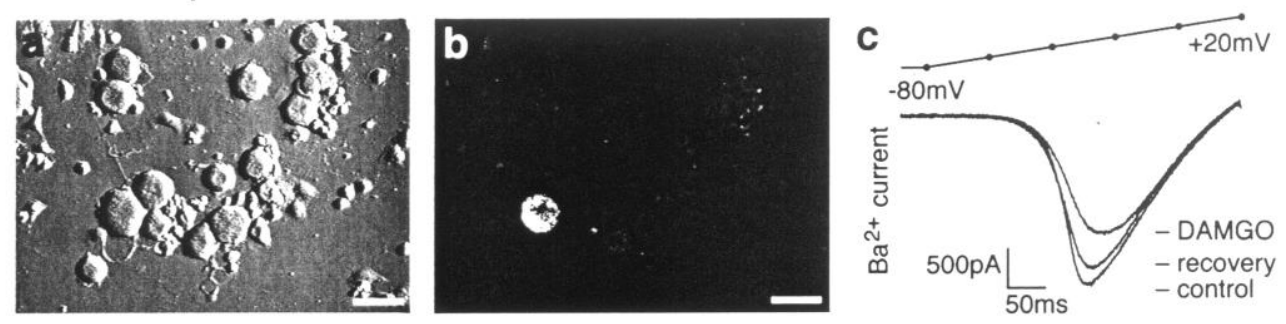

B Mechanosensors
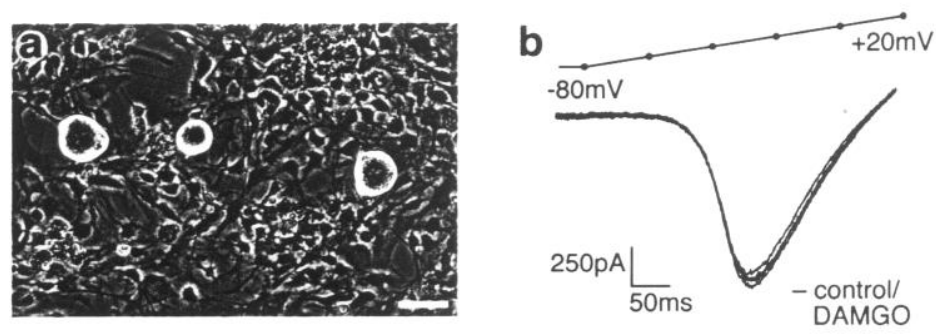

Table 1. MOR sensitivity and mRNA in Nociceptive and Non-Nociceptive Sensory Neurons

\begin{tabular}{|l|l|l|}
\hline & $\begin{array}{l}\mathrm{Ca}^{2+} \text { channel inhibition } \\
\text { above } 10 \%\end{array}$ & Detectable \\
& MOR mRNA \\
\hline Nociceptors & $77 / 182$ & $109 / 191$ \\
\hline Mechanosensors & $0 / 20$ & $2 / 72$ \\
\hline
\end{tabular}




\section{Strategy For Counting mRNA In Individual Cells}

To ask whether selective gene transcription enables opioids to target nociceptors and spare mechanosensors, we harvested individual neurons of identified sensory modality and performed quantitative RT-PCR to detect and count MOR mRNA in each cell. A variation of competitive PCR (Gilliland, Perrin et al. 1990; Buzas and Cox 1997) was used to quantify MOR cDNA in each cell. In addition, we measured RT reaction efficiency for each cell (the number of cDNAs generated per RNA), by dividing MOR cDNA number by RT efficiency, giving the number of MOR mRNA molecules per cell. Our method also explicitly indicates when there has been a failure in any given cell of PCR, RT, or cell harvest, thereby enabling us to eliminate these false negatives from data sets.

The essential controls are: 1) measurement of a constitutively expressed "housekeeping" gene (glyceraldehyde-3-phosphate dehydrogenase, GPD, a metabolic enzyme) for each cell; 2) addition, into each PCR tube, of a known amount of a mutant DNA that binds the same PCR primers as the target wildtype DNA, and measurement of the ratio of wildtype:mutant PCR products; 3) a calibration ladder made for each PCR run by co-amplifying known amounts of the mutant and wildtype DNAs; 4) addition of a known amount of a mutant GPD RNA to quantify each RT reaction. Also, rather than harvesting a variable amount of cytoplasm as commonly done in single cell RT-PCR methods (Sucher and Deitcher 1995), we picked up the entire cell so the total cell content for each mRNA studied could be reported. The numbers of molecules seeded into calibration ladders were chosen after finding the typical amounts of mRNAs from 
individual cells. A cell with robust expression might have 100 copies of MOR, 1000 copies of neurokinin peptide (data not shown), and 10,000 copies of GPD mRNAs.

Figure 3 shows data from 12 individual cells (lanes A-L). The RT products were divided and the MOR (upper gel) and GPD (lower gel) cDNAs were amplified by PCR in two stages using two pairs of nested primers. The final PCR products span at least one intron, thereby allowing distinction between genomic and cDNA. The predicted lengths of second stage MOR and GPD PCR products are 290 and $241 \mathrm{bp}$, respectively, the positions marked "wt" on the ethidium-stained agarose gels. The DNA mutants (mut and m1) are longer, having an 85 basepair insert between the PCR primer sites, and their PCR products appear as an additional band just above wt. Another mutant GPD—marked " $\mathrm{m} 2$ " and having a 268 basepair insert—was added as synthetic RNA prior to RT, thereby allowing measurement of RT efficiency.

A DNA calibration ladder occupies the left 7 lanes of each gel. These reaction tubes were seeded with the indicated number of cloned wildtype DNA molecules and with the same number of mutant DNAs that are seeded into the other tubes of the PCR (either 12 copies of the MOR mutant or 500 copies of the m1 GPD mutant). Tubes for the calibration ladder, the cells, and the controls go through the thermal cycling sequence together and are prepared with the same enzyme stocks. The ratios of wildtype:mutant band intensities for the calibration lanes are plotted against the initial wildtype DNA content (open symbols, Figure 3B) and fit with a polynomial function (curve). The initial quantity of cellular cDNA for cells A-L is then calculated from the corresponding intensity ratios (solid symbols) and the polynomial function. Multiplying by 2 gives the total cellular MOR cDNA because half of the RT mix was used for the MOR PCR. 
Importantly, this method does not assume that the overall PCR efficiency is the same in each tube (analyzing by ratios controls for that), nor does it require that wildtype and mutant sequences are copied with identical efficiency. We only assume that if the initial ratio of wildtype:mutant DNA is the same in the calibration and the cell tubes, then the ratio of the PCR products will be the same in the two tubes. Equal starting amounts of wildtype and mutant MOR DNA yields a final product ratio of about 0.7 in our conditions (For a particular sequence pair, this value can vary greatly with $\mathrm{Mg}^{2+}$ and DMSO concentrations. We empirically adjusted these concentrations in preliminary experiments and kept them constant thereafter).

Reverse transcription was primed with random hexamers. We quantified RT efficiency (cDNA/RNA) as described below and found that, unlike PCR, it varied considerably in different reaction tubes. For example, for the 120 cells in Figure 6, the average number of cDNA made per RNA was $0.175( \pm 0.019 \mathrm{sem})$, the median was 0.123 , and $50 \%$ of the cells fell between 0.056 and 0.194 . To control for such tube-to-tube variation in RT, a cell's content of MOR mRNA was calculated by dividing its cDNA content by RT efficiency. Noise in our data was clearly less after correcting for RT efficiency, but the general trends were evident when data was plotted as either cDNA or mRNA.

The amount of GPD cDNA and GPD mRNA were both measured in each cell and the ratio of the two numbers was taken to be the RT efficiency for that cell's reaction. GPD cDNA was obtained by seeding the PCR with a known amount of mutant DNA (m1). GPD mRNA was obtained by seeding the preceding RT with a known amount of mutant RNA (m2). Wildtype and $\mathrm{m} 2$ RNAs go through the RT reaction together and the 
cDNA products go through the PCR together. If each is transcribed and amplified with the same efficiency, then the ratio of their band intensities on the gel equals the ratio of their starting mRNA. However, PCR amplification varies with different sequences and with the starting amount of DNA, so we use the calibration ladder to control for this. For example, in the calibration tube seeded with the same numbers (500) of both wildtype and $\mathrm{m} 2$ DNAs, the ratio of PCR product bands was 0.6. Therefore, a cell that has a product ratio of 0.6 had the same number of wildtype and $\mathrm{m} 2 \mathrm{cDNAs}$ prior to PCR. We then assume that they had the same starting number of wildtype and m2 RNA. This presumes that the relative RT efficiency for wildtype and m2 RNA does not vary from tube to tube and should be close to 1 . If this same RT efficiency applies perfectly to MOR mRNA, then using it provides the absolute number of MOR mRNA in a particular cell. Even if RT efficiency is not identical for all sequences, division by it normalizes against tube-to-tube variations in RT efficiency. We found the variation to be substantial and, so, consider the correction important.

In addition to quantification, this method generates explicit fingerprints of three possible artifacts that can falsely suggest the absence of MOR mRNA: failures of the PCR, the RT, or the cell harvest. If PCR of the MOR sequence fails in a tube, there is no mutant MOR band. If RT fails, there are no GPD bands for wt or m2. If the cell was not successfully placed in the reaction tube, the wt GPD band is absent, but $\mathrm{m} 2$ is present (For example, the final lane is a sham harvest.). In practice, the PCR and RT rarely fail, but about $10 \%$ of cell harvests fail. In Figure 3, cells B, C, I and L had no detectable MOR cDNA and no artifact; thus, expression remained below our detection threshold of 2 MOR cDNA per tube. Dividing by 0.5 , the fraction of the RT mix used for MOR PCR, 
gives the cellular detection threshold for MOR cDNA (4 per cell); dividing again by 0.175 , the average RT efficiency, gives the average threshold for detecting MOR mRNA (23 per cell). Distributed evenly throughout a $30 \mu \mathrm{m}$ spherical cell, this would be $2 \mathrm{pM}$ MOR mRNA. 


\section{Legend, Figure 3}

(A) PCR products for MOR (upper) and GPD (lower) of 12 nociceptor neurons (lanes A-L) and 7 calibration tubes (left lanes). w.t. Bands: wildtype MOR and GPD DNA. mut and m1 Bands: mutants of MOR and GPD DNA having 78 and $88 \mathrm{bp}$ insertions between primer sites; 12 and 500 molecules, respectively, were seeded into each PCR tube. RT reactions were seeded with indicated amount of synthetic $\mathrm{m} 2$ RNA containing a 268 bp insertion. Calibration tubes contain the indicated number of wildtype MOR or GPD DNA and either 12 (MOR) or 500 (GPD) mutant molecules. The final lane, "Sh", from a sham harvest, has no wt MOR, but mut and $\mathrm{m} 2$ bands confirm that PCR and RT worked. Cell I, which also has no detectable wt MOR, has wt GPD, mut and $\mathrm{m} 2$; showing that RT, PCR, and harvest were all successful, and that MOR mRNA in cell I was truly undetectable.

(B) MOR bands were quantified (MOR numbers below gel) by comparison to calibration ladders and correction for RT efficiency. Ratios of wildtype:mutant band intensities in each calibration tube are plotted against the number of initial wildtype molecules (open symbols). Curves fit to these data are used to interpolate initial cellular wildtype content from the wt:mutant product ratios from each cell (solid symbols). The second GPD mutant, m2, enables measurement of GPD mRNA for each cell. w.t./m1 and w.t./m2 ratio calibrations are plotted separately to measure harvested cDNA and mRNA, respectively. The ratio of GPD cDNA:mRNA is taken as the RT efficiency for a given cell. Dividing MOR cDNA by RT efficiency gives MOR mRNA. RT efficiency varied in different cells; data from cells $\mathrm{A}$, J, and $\mathrm{K}$ illustrate effects of this. 
Figure 3. Use of competitive RT-PCR to quantify single cell MOR and GPD mRNAs
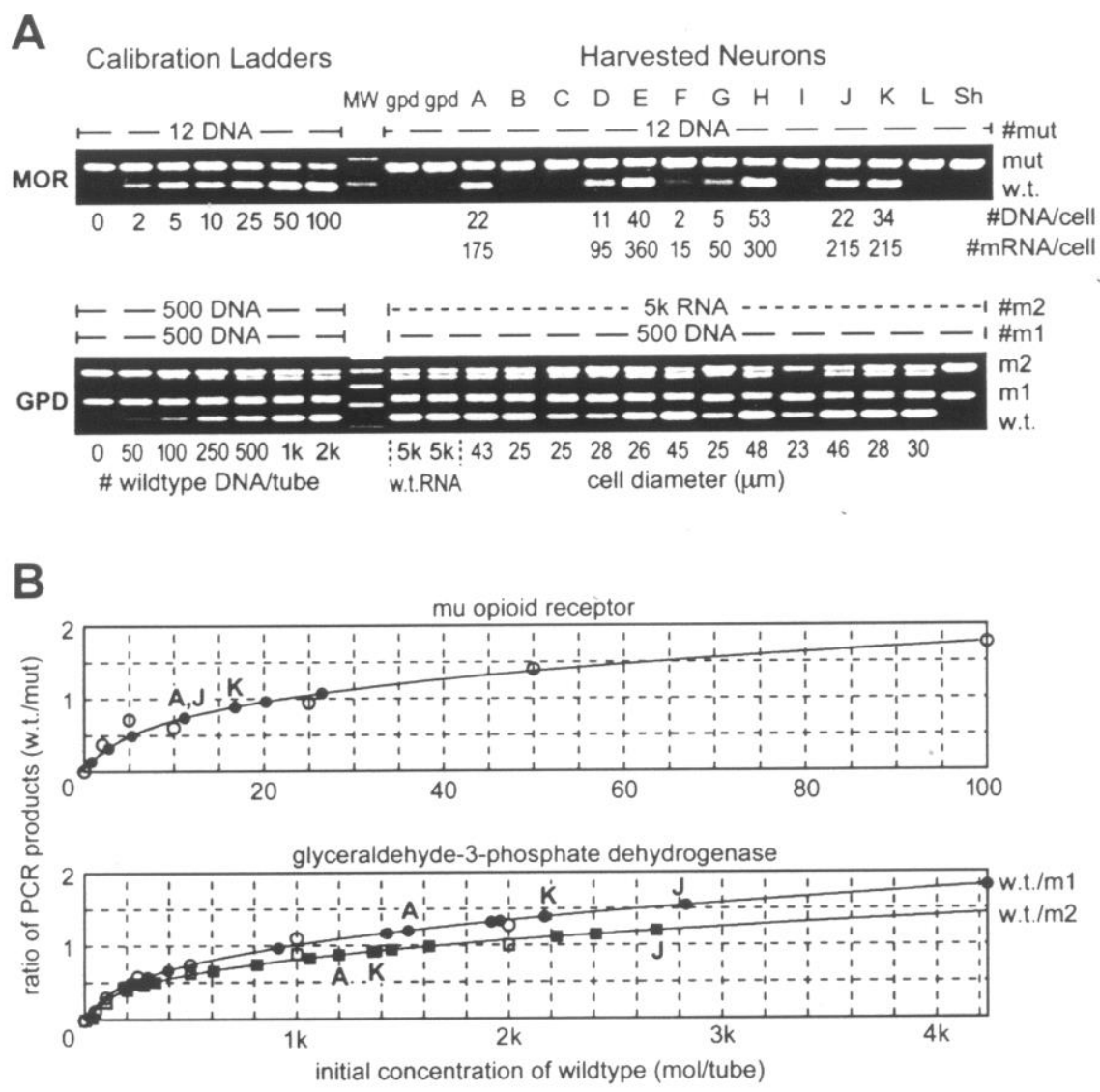
We considered two possible reasons why only nociceptors respond to opioids. The first — selective expression of the opioid sensitive N-type $\mathrm{Ca}^{2+}$ channel—was ruled out because an $\mathrm{N}$ channel-specific toxin, $\omega$-conotoxin GVIA, inhibited $\mathrm{Ba}^{2+}$ currents to the same degree on mechanosensors and nociceptors $(44 \pm 4 \%, n=6$, and $41 \pm 3 \%, n=12$, respectively). The second — selective expression of MOR — was tested using single cell RT-PCR to measure MOR mRNA. In Figures 3 (lanes A-L) and 4A (lanes A-O), all 27 cells were fluorescently labeled tooth pulp nociceptors. A total of 191 nociceptors were tested and most $(60 \%)$ contained detectable MOR mRNA. The level varied extensively among the positives: the average number of copies was 227 , the median 160 , and $50 \%$ of the positives were between 60 and 290 copies. These small numbers contrast with the average of 13,100 copies of GPD mRNA in the same cells.

We tested 72 individual MeN5 mechanosensor neurons and only 2 had detectable MOR mRNA; one of these appears in Figure 4B (lane I). The absence of MOR mRNA in the overwhelming fraction of non-nociceptive sensory neurons suggests that only nociceptors transcribe the MOR gene. This selective gene transcription can explain why opioids inhibit pain but not other sensations.

The two neurons in the MeN5 preparations with detectable MOR mRNA suggest that occasional mechanosensors express significant levels of the message. Alternatively, many mechanosensors express MOR, but at levels usually below our detection threshold. We distinguished these alternatives by harvesting another 40 MeN5 neurons and pooling them into 6 tubes ( 4 with 5 cells each and 2 with 10). MOR mRNA was present in only 3 of these samples, at levels $(50,100$, and 250 molecules $)$ similar to levels in single nociceptors and similar to the two individual positive MeN5 cells (lane A in Figure 4B is 
one of the positive pooled samples; lanes B and $\mathrm{J}$ are negative pools). All pools should be positive if mRNA was present in the majority of cells at levels just below our detection threshold. Thus, there are rare cells in the MeN5 preparation with substantial MOR mRNA. Possibly, this is an artifact - our preparation could be contaminated with non-sensory neurons such as MOR-rich cells from the neighboring locus coeruleus (Ingram, Wilding et al. 1997). In this case, all MeN5 neurons fail to transcribe MOR and the few positives are cellular contaminants. A second, more interesting possibility is that the positive cells reflect anomalous MOR transcription in rare MeN5 neurons. This may be the single cell equivalent of "transcriptional leak" described by (Sarkar and Feigelson 1989). That is, "leak" is due to a small fraction of cells that escape transcriptional control rather than all cells having a low level of transcription. 


\section{Legend, Figure 4}

A. MOR and GPD mRNA amplified and quantified from 15 single nociceptors (lanes A-O). MOR mRNA expression spans from below the detection threshold to 460 molecules/cell, which is $60 \mathrm{pM}$ assuming equal distribution throughout the spherical cell. Labels follow description in Figure 3 legend.

B. MOR and GPD mRNA amplified and quantified from 7 individual MeN5 neurons (lanes C-I) and 3 pooled samples of either 5 (lanes A, B) or 10 (J) MeN5 neurons. Cell I is one of only 2 (out of 72) individually harvested MeN5 neurons that had detectable MOR mRNA. See text for discussion of these rare positives. The numbers in parentheses are the average diameter of cells in the pooled sample. Other labels as described in Figure 3 legend. 
Figure 4. Most Nociceptors, but only Rare Mechanosensors, Transcribe MOR mRNA
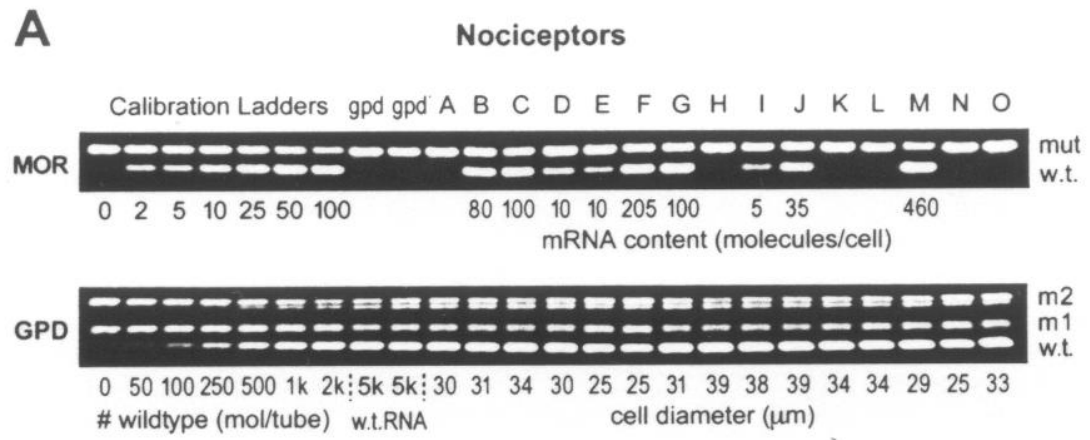

B Mechanosensors
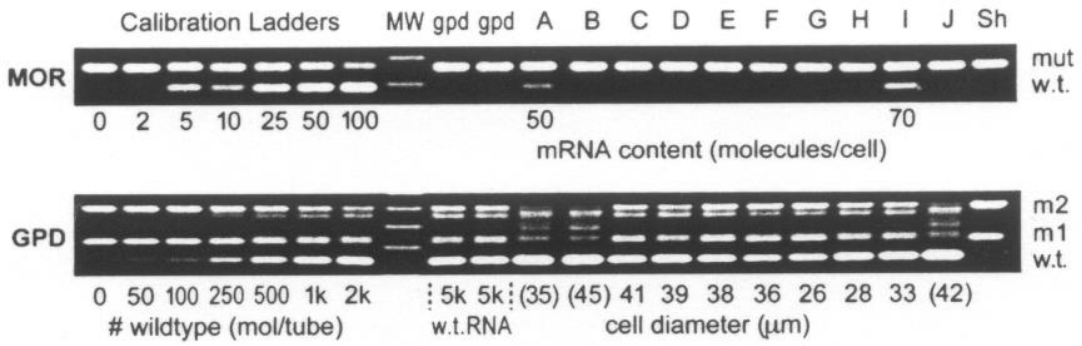


\section{Low MOR mRNA in Large Nociceptors}

Might selective transcription also explain why opioids fail to suppress antinociceptive reflexes? This could occur through selective suppression of MOR mRNA in myelinated nociceptors, the cells that trigger these reflexes. Tooth pulp is well suited for addressing this question because it has clear psychophysical correlates to first and second pain. Myelinated pulp afferents mediate sharp, shooting pain while unmyelinated afferents mediate dull, persistent toothache (Jyvasjarvi and Kniffki 1987). The intensity of acute tooth pain increases strictly in parallel with the integrated electrical activity of myelinated axons emanating from the tooth (Fors, Ahlquist et al. 1984), arguing that all, or virtually all, of these myelinated axons are nociceptive. This contrasts with $A \alpha / B$ and A $\delta$ myelinated axons that innervate skin, of which $30 \%$ and $60 \%$ are nociceptors, respectively (Djouhri, Bleazard et al. 1998).

Dissection severs axons, so we inferred myelination of dissociated pulp afferents from their cell body diameter. The smallest sensory neurons reliably have unmyelinated axons, the largest have myelinated, and there is, at best, a loose correlation between size and myelination for intermediate cell body sizes (Harper and Lawson 1985; Lee, Chung et al. 1986). We measured Ca channel inhibition by DAMGO in 182 tooth pulp afferents. Ranking them by cell diameter reveals that opioid sensitivity tends to decrease as cell size increases: the rank-based Spearman correlation coefficient, $\mathrm{r}_{\mathrm{s}}$, equals 0.19 ; there is a $1 \%$ probability $(\mathrm{P}=0.011)$ that this correlation could occur if opioid response were unrelated to cell body size. The basis of the correlation is evident when data are binned into size ranges (Figure 5A). The largest cells (diameters $\geq 40 \mu \mathrm{m}$ ), those most likely to be myelinated, have a low average response to DAMGO (solid bars), and only a third of the 
large nociceptors were substantially $(\geq 10 \%)$ inhibited (hatched bars). The results qualitatively agree with our previous report (Taddese, Nah et al. 1995), which suggested that the opioid response is less in myelinated than in unmyelinated nociceptors.

We measured mRNA levels in 191 tooth pulp afferents that ranged from 20 to 50 $\mu \mathrm{m}$ in diameter. The number of mRNA molecules for GPD, the housekeeping gene, systematically increased with cell diameter $\left(r_{s}=0.49\right)$; thus the probability is vanishingly low $(\mathrm{P}<0.0001)$ that such a correlation could occur if GPD mRNA were unrelated to cell diameter. This indicates that, as expected, mRNA production increases with cell diameter. The hatched bars in Figure 5B show the average GPD mRNA count in 3 different bins of cell body diameter, demonstrating the systematic increase in mRNA with size.

In contrast to results with GPD mRNA, the same cells exhibited no such correlation between MOR mRNA and cell diameter $\left(r_{s}=-0.085, P=0.24\right)$, as shown by the binned and averaged data in Figure 5B. Average MOR mRNA number (solid bars) increases with cell size between the small and medium cell bins, but then drops off in the largest cells. Normalizing MOR to GPD mRNA content for each cell underscores that MOR mRNA expression is low in the largest cells (inset, Figure 5B). Normalizing by cell volume (Figure 5C) or surface area (inset) also shows that MOR mRNA is particularly low in the largest cells. Thus, regardless of how it is expressed, MOR mRNA is like the response to opioids: both are low in large tooth pulp afferents, the group most likely to have myelinated axons.

Though the physiological evidence (Edwall and Olgart 1977; Ahlquist, Edwall et al. 1984; Narhi, Yamamoto et al. 1994; Hildebrand, Fried et al. 1995) argues otherwise, 
we considered the possibility that some tooth pulp afferents are non-nociceptive. If so, this could yield the above results for a trivial reason: the population of large neurons might be enriched in non-nociceptors that contribute nothing to the average MOR mRNA. However, the data argues otherwise because there are similar fractions of cells with detectable MOR mRNA in each size range. 60 percent of small cells, 63 percent of medium cells, and 50 percent of large cells have detectable levels of MOR message. MOR mRNA is lower in the largest cells than the medium ones, indicating that, when they have it, large nociceptors have lower amounts of MOR mRNA than expected for their large volume. This contrasts with non-nociceptive neurons, which simply fail to express MOR mRNA (Figure 4; Table 1), and suggests the possibility that fine control of MOR mRNA level in nociceptors can control their opioid sensitivity. 


\section{Legend, Figure 5}

(A) Average $( \pm \mathrm{SEM})$ percent $\mathrm{Ca}^{2+}$ channel inhibition by $1 \mu \mathrm{M}$ DAMGO (black, left axis) and the fraction ( $\pm 68 \%$ confidence interval) of cells inhibited by more than $10 \%$ (hatched, right axis) in nociceptors of different cell body diameters. There were nonresponders and very large responders (>40\% inhibition) in each bin, confirming heterogeneity in each group.

(B) The average number of MOR mRNA molecules (black, left axis) or GPD mRNA molecules (hatched, right axis) for nociceptors of different cell body diameter. The number of GPD mRNA molecules increases with increasing size, as expected when an increasing amount of cytoplasm is harvested. In contrast, the number of MOR mRNA drops in the largest cells. Inset: The average ratio $\left(\mathrm{x} 10^{3}\right)$ of MOR:GPD mRNA for large nociceptors is less than for small or medium.

(C) The average concentration (moles/volume assuming a spherical cell) of MOR mRNA (black, left axis) is lowest in the largest nociceptors and drops more than the concentration of GPD mRNA (hatched, right axis). Inset: The average MOR (black, left axis) and GPD mRNAs (hatched, right axis) per $100 \mu \mathrm{m}^{2}$ of cell surface area, assuming a spherical shape. 
Figure 5. Large Nociceptors Have Low Opioid Response and Have Low MOR mRNA Levels.

a
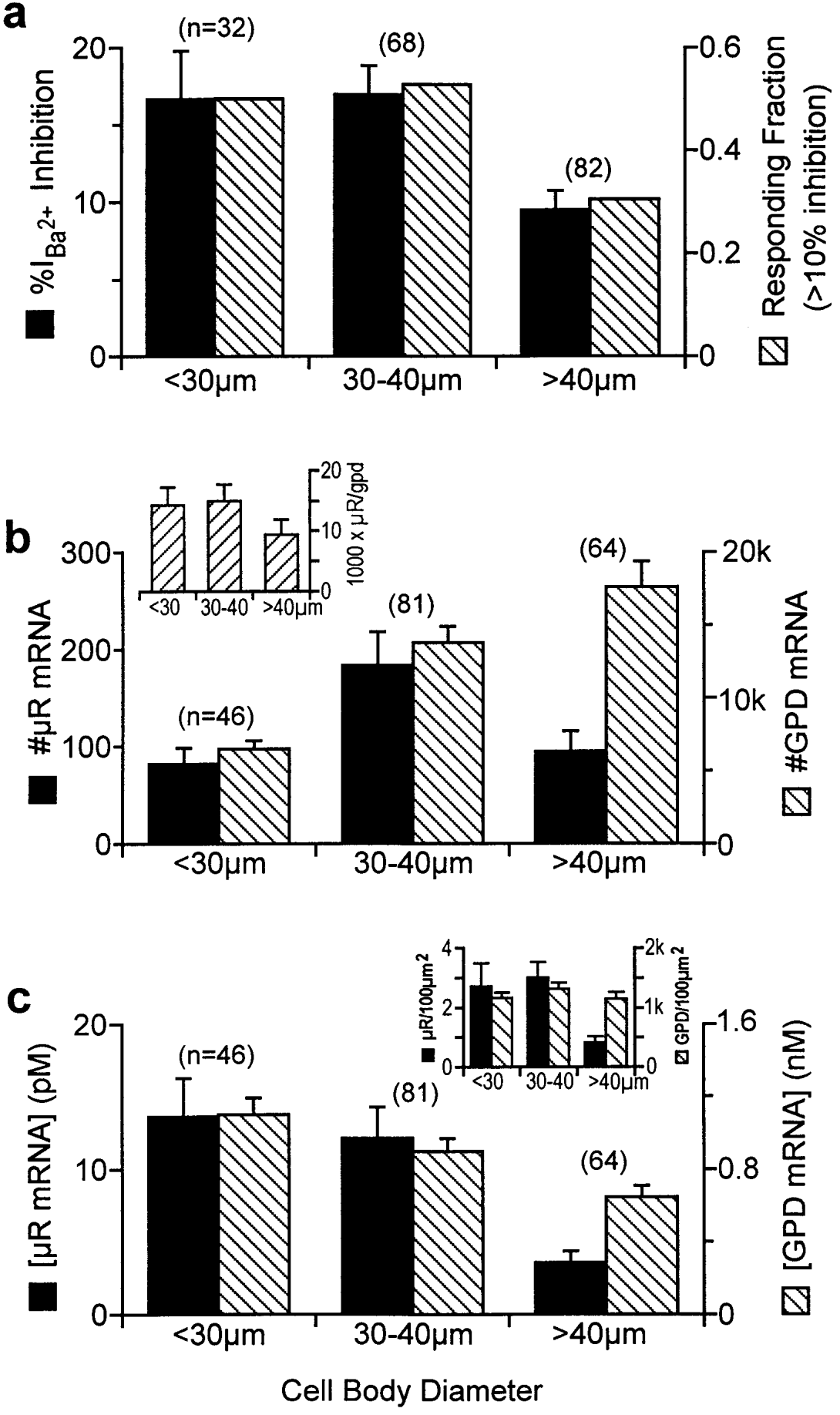


\section{Relation between MOR mRNA Concentration and $\mathrm{Ca}^{2+}$ Channel Inhibition in Single Nociceptors}

The fact that MOR mRNA level and opioid sensitivity both drop in large nociceptors suggests that the one limits the other. This is hardly an obvious conclusion because at least 8 transcripts contribute to making the complex of proteins (receptor, $\mathrm{G}$ protein, $\mathrm{Ca}$ channel) required to mediate the opioid response; moreover, mRNA levels sometimes do (Baro, Levini et al. 1997; Tkatch, Baranauskas et al. 2000) and sometimes do not (Xu, Dixon et al. 1996) predict protein levels. To explore the question, we analyzed the data from the 120 nociceptors in which we measured both Ca channel inhibition and MOR mRNA level. Each point in Figure 6A expresses, for a particular cell, the percent inhibition by DAMGO (vertical axis) and the concentration of MOR mRNA (horizontal axis). We used concentration (moles MOR mRNA / cell spherical volume) to control for the 15 -fold span of cell volumes between the different sized nociceptors.

Of the 120 cells, 51 had no MOR mRNA above detection threshold, only 4 of which had opioid inhibition greater than $10 \%$. In contrast, most that had detectable MOR mRNA had obvious responses to DAMGO. The dashed line represents the best fit to the data of a single-site binding curve $\left(\mathrm{B}_{\max }=35 \%, \mathrm{~K}_{1 / 2}=5.4 \mathrm{pM}\right)$. Binning and averaging the data clearly demonstrates a saturable dose-response relation (Figure 6B): $\mathrm{Ca}^{2+}$ channel inhibition increases with MOR mRNA concentration up to about $15 \mathrm{pM}$, but is maximal above 15 pM. Figure $6 \mathrm{C}$ plots, for each bin of mRNA concentration, the fraction of cells whose $\mathrm{Ca}^{2+}$ channels were inhibited by more than $10 \%$; the prevalence of these stronger opioid responders increases with mRNA concentration up to $15 \mathrm{pM}$, and then saturates. 
Evidently, even though opioid inhibition of $\mathrm{Ca}^{2+}$ channels is a multi-protein reaction, expression of mRNA for one of the proteins, MOR, is rate limiting in that low concentrations limit the cellular response in a substantial fraction of nociceptors

This dose-response relation offers two possible mechanisms to explain the relative resistance of large nociceptors to opioids: 1) few large nociceptors express MOR; 2) large nociceptors express MOR mRNA, but at levels below $15 \mathrm{pM}$ where $\mathrm{Ca}^{2+}$ channel inhibition is limited. The first mechanism could be implemented by simply turning off transcription in most large nociceptors. The second implies that quantitative regulation of mRNA level limits the sensitivity of large nociceptors. Because large nociceptors are only slightly less likely to express detectable MOR mRNA than smaller ones, the second mechanism seems likely. As a further test of this, Figure 7A gives, for nociceptors that had detectable MOR mRNA, the average concentration (solid bars) and the fraction of the cells that expressed above $15 \mathrm{pM}$ (hatched bars), the range at which opioid sensitivity is maximal. The vast majority of large nociceptors that have detectable MOR mRNA express it below $15 \mathrm{pM}$, concentrations that are insufficient to generate a maximal opioid response. From the data in Figures 6 and 7, we conclude: 1) the opioid sensitivity of a nociceptor can be limited by its cellular concentration of MOR mRNA; 2) this mechanism limits the opioid sensitivity of large, myelinated nociceptors. 


\section{Legend, Figure 6}

A. Percent inhibition of $\mathrm{Ca}^{2+}$ channels by DAMGO vs. cellular MOR mRNA concentration for 120 tooth pulp afferents (each point from a single cell). Concentration rather than copy number was used so the horizontal axis is proportional to the cell's chemical activity of MOR mRNA despite the wide variation in the volume of different sized neurons. The origin $\left(0^{*}\right)$ has 51 points and indicates that MOR mRNA was not detected in those cells. The dashed curve is the best fit $\left(\mathrm{R}^{2}=0.51\right)$ of the equation: $\%=$ $\mathrm{B}_{\max }\left([\mathrm{M}] /\left([\mathrm{M}]+\mathrm{K}_{1 / 2}\right)\right)$ where $[\mathrm{M}]$ is the concentration of MOR mRNA; $\mathrm{B}_{\max }=35 \%$ and $\mathrm{K}_{1 / 2}=5.4 \mathrm{pM}$.

B. The same data expressed as averages $( \pm$ SEM $)$ for bins of MOR mRNA concentrations. The average opioid response systematically rises with MOR mRNA concentration until it saturates at $15 \mathrm{pM}$ and above. Number of cells in each bin indicated within the bars. Except for the 10-15 pM vs.>25 pM values, non-neighboring bins differed with $\mathrm{P}<0.05$.

C. The fraction of cells ( $\pm 68 \%$ confidence interval) that had greater than $10 \%$ inhibition by DAMGO vs. MOR mRNA concentration. Almost all cells with more than 15 pM MOR mRNA had such sizeable opioid responses. 
Figure 6. Opioid Sensitivity Is Limited When MOR mRNA Is Below 15 pM
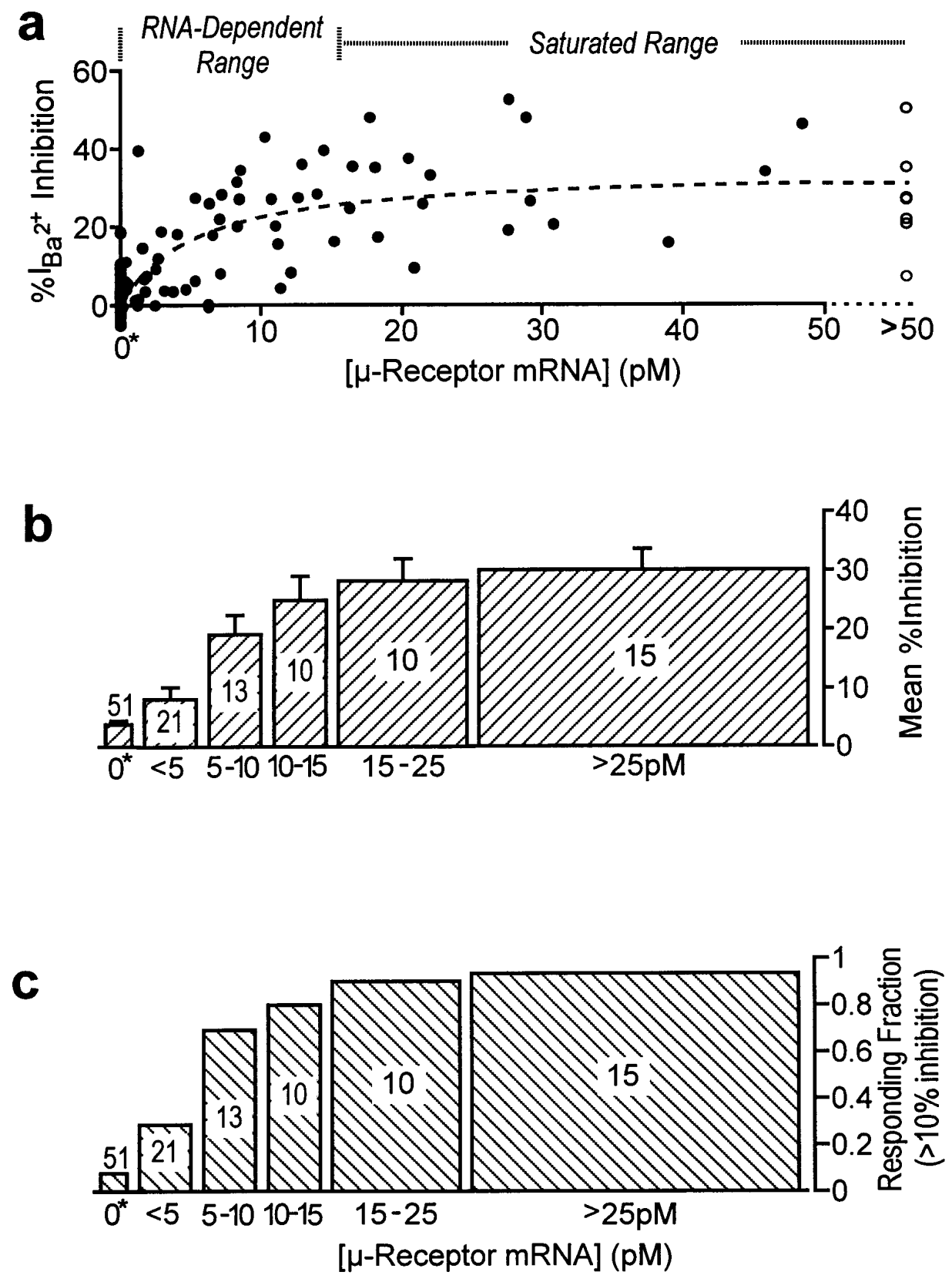


\section{Summary, results chapter I}

Slowly transmitted pain sensation is selectively blocked by opiates and the endogenous opioid pain control system. While other modalities such as proprioception, nociceptive reflexes and touch sensation remain unaffected, patients under opiate analgesia cannot feel the pain of a recent injury that caused pain when it was inflicted.

We hypothesized that these sensations are spared by the spinal opioid system and analgesic doses of morphine by producing low or nonexistent levels of MOR molecules on the sensory neurons that relay immediate damage or non-pain information. We tested this hypothesis with assays for MOR expression and opiate sensitivity on nociceptive and non-nociceptive sensory neurons, and found that only nociceptive sensory neurons expressed MOR mRNA and MOR agonist sensitivity. When we quantified the levels of MOR mRNA found on nociceptors, we found that the levels of MOR mRNA were highest in the cells that showed the greatest sensitivity to the MOR agonist DAMGO, and that concentrations of $15 \mathrm{pM}$ MOR mRNA or greater were required to generate detectable opioid responses. Large diameter cells usually had levels below 15 pM, while small diameter cells usually had levels above $15 \mathrm{pM}$. This was the opposite of the trend seen with a control mRNA species encoding a metabolic enzyme, whose concentration steadily increased with cell size, indicating that MOR mRNA is regulated in nociceptors to selectively block lasting pain signals and not nociceptive reflex or non-nociceptive signals. 


\section{Results, Chapter II}

Dynorphin Modulation of Sensory and Locus Coeruleus Neurons Through the mu Opioid Receptor 


\begin{abstract}
Opioids inhibit high-voltage activated (HVA) calcium channels to widely different degrees in primary sensory neurons, as would be expected since each cell transduces a particular sensation. Despite such cell-to-cell variation, we found that dynorphin and DAMGO — agonists of the kappa (KOR) and mu (MOR) opioid receptors, respectivelyinhibit HVA calcium channels almost identically to each other on all opioid-sensitive sensory neurons. This suggests that both receptor subtypes are highly co-localized. We tested this expectation using quantitative RT-PCR on single cells and found it false: many neurons express MOR mRNA, but very few cells express KOR mRNA. Three observations indicate that this discrepancy between dynorphin action and KOR expression occurs because dynorphin acts through MOR: 1) CTAP, a MOR antagonist, inhibited dynorphin action on all cells tested; 2) U-69593, a different KOR agonist, inhibited HVA calcium channels on a very small fraction of cells that responded to dynorphin; 3) NOR-BNI, a KOR antagonist, fully suppressed U-69593 action on these rare cells, and only partially attenuated the inhibition by dynorphin. To ask if the sensory neuron MOR is uniquely non-selective, we performed analogous experiments on rat locus coeruleus slices, a tissue rich in MOR and devoid of other opioid receptors. The results were identical. We conclude that MOR expression is sufficient to render neurons sensitive to dynorphin, and that sensory neurons rarely express KOR.
\end{abstract}




\section{Introduction}

Dynorphin A (1-17) is a member of the family of endogenous opioid

neuropeptides, which includes the enkephalins, the endorphins and several other forms of dynorphin. These peptides suppress neuronal excitability in a variety of tissues, and their receptors are widely expressed throughout the central and peripheral nervous system. Through the action of these receptors, opioids modify many and diverse physiological processes including pain transmission, gastrointestinal mobility, sexual behaviors, arousal and reward (Fields 1987; Kieffer 2000). With isolation of the opioid peptides and the characterization of numerous opiate effects in whole animal and tissue preparations, exhaustive searches for their corresponding receptors have yielded only three full length clones, corresponding to their pharmacologically identified subtypes: the mu (MOR), delta (DOR), and the kappa (KOR) opioid receptors (Massotte and Kieffer 1998). While morphine has activity at all three opioid receptors, gene disruption experiments have shown that MOR is the principal player in morphine dependence and morphine-induced analgesia, (Matthes, Maldonado et al. 1996) as well as the analgesia produced through the activation of the endogenous opioid system (Sora, Takahashi et al. 1997).

Morphine's ability to selectively block pain is an effect that is dominantly mediated by the MOR when it is administered at analgesic doses (Goldstein and Naidu 1989; Raynor, Kong et al. 1994; Williams, Christie et al. 2001). At the cellular level, this blockade is manifested as a decrease in the strength of neurotransmission between neurons of the pain pathway (Kohno, Kumamoto et al. 1999). Depending on their locus of expression and subtype, opioid receptor activation dampens neuronal excitability through the $G$ proteins $G_{i}$ and $G_{o}$ to cause decreases in cytosolic cAMP, activation of 
membrane potassium channels, and/or inhibition of high voltage activated (HVA) calcium channels (Williams, Egan et al. 1982; Yoshimura and North 1983; Schroeder, Fischbach et al. 1991). Voltage clamp studies have shown that calcium channel inhibition is the only electrical pathway effected by MOR on sensory neurons (Schroeder, Fischbach et al. 1991; Akins and McCleskey 1993), and opioids have been shown in several preparations to powerfully diminish the release of neurotransmitter chemicals and peptides from these cells (Jessell and Iversen 1977; Kohno, Kumamoto et al. 1999). Additionally, Vaughn and colleagues have shown that MOR-selective ligands inhibit neurotransmission in the dorsal horn of the spinal cord via a presynaptic mechanism, while KOR and DOR selective ligands were without effect on evoked synaptic currents (Vaughan and Christie 1997).

Dynorphin is considered the endogenous KOR ligand because of its similarity to prototypic KOR opiate agonists in early binding and activity assays (Huidobro-Toro, Yoshimura et al. 1981; Wuster, Rubini et al. 1981; Chavkin, James et al. 1982). However, some evidence indicates that dynorphin can act at sites other than KOR. The MOR antagonist $\beta$-funaltrexamine was later shown to block dynorphin actions on hippocampal CA1 pyramidal neurons (Chavkin, Henriksen et al. 1985), and in cell-free binding assays, $\left[{ }^{3} \mathrm{H}\right]$-dynorphin binding to membranes prepared from brain tissue was not completely displaced by any single ligand except for dynorphin itself (James, Chavkin et al. 1982). Porecca and collaborators describe a growing list of non-opioid actions of dynorphin (Tang, Lynch et al. 2000), and recent work in heterologous expression systems has shown that while dynorphin has slight preference for KOR, it also binds and potently stimulates all three cloned opioid receptors and the non-opioid ORL receptor (Zhang, 
Tong et al. 1998). From this evidence, Kieffer and colleagues have concluded that dynorphin could be an endogenous ligand at all of the opioid receptors (Zhang, Tong et al. 1998).

Dynorphin has been used by our lab and others to show that the KOR links to HVA calcium channels in sensory neurons, which often express high levels of the MOR (Schroeder, Fischbach et al. 1991; Moises, Rusin et al. 1994; King, Hall et al. 1999). In light of the possible cross-reactivity of dynorphin with other opioid receptors, we reinvestigated the presence of KOR on sensory neurons using electrophysiology in combination with the quantitative RT-PCR assay on single sensory neurons described in results chapter one. In this new study, we found that the magnitudes of DAMGO and dynorphin inhibition dynorphin of HVA calcium channels on rat sensory neurons were always similar, but that dynorphin usually acts through the MOR on opioid sensitive cells. This was also true of locus coeruleus neurons from the rat, a tissue devoid of KOR (Williams and North 1984). While sensory neurons certainly do express KOR, we conclude from these studies on native receptors that KOR is rarely expressed on sensory neurons, and that expression of MOR by these cells can make them sensitive to dynorphin, perhaps as an endogenous ligand.

\section{Results}

\section{Sensory Neuron Responses to DAMGO and Dynorphin are Equal in Size}

As a means to study the opioid sensitivity of sensory neurons, we measured the inhibition of barium currents $\left(\mathrm{I}_{\mathrm{Ba}}{ }^{2+}\right)$ through HVA calcium channels. This is the only electrical pathway affected by opioids on sensory neurons, (Schroeder, Fischbach et al. 1991) and opioid receptor inhibition of HVA calcium channels is an important 
mechanism underlying the block of synaptic transmission from nociceptive (pain detecting) sensory neurons in the dorsal horn of the spinal cord (Yaksh, Jessell et al. 1980; Vaughan and Christie 1997; Kohno, Kumamoto et al. 1999). As previously shown, maximally active doses of opioid peptides applied to sensory neurons resulted in a wide range of responses, from 0 to around $40 \%$ inhibition of HVA calcium currents on sensitive neurons (Moises, Rusin et al. 1994; Taddese, Nah et al. 1995; Abdulla and Smith 1998). Also see figure six, results chapter one.

Figure 1 shows examples of responses from two cells, one that is opioid responsive (Figure 1a) and one that is not (Figure 1b). Figure 1c is a scatter plot of the corresponding DAMGO and dynorphin responses from 89 sensory neurons, recorded in both the whole cell and perforated patch configurations. In comparing the responses to DAMGO and dynorphin on these cells, we obtained near-equal values for DAMGO and dynorphin inhibition in all ranges, with a Pearson correlation coefficient of 0.84 . The effects of both peptides were highly sensitive to the cone snail toxin $\omega$-conotoxin GVIA, and could be relieved by depolarizing prepulses, (not shown) indicating that N-type high voltage gated calcium channels are the primary electrical effector system that is modulated by opioids on these cells (Schroeder, Fischbach et al. 1991), most likely through the actions of $\mathrm{G}_{\beta \gamma}$ (Herlitze, Garcia et al. 1996; Ikeda 1996). 


\section{Legend, Figure 1}

a. Effects of $1 \mu \mathrm{M}$ DAMGO (left, asterisk) and dynorphin (right, asterisk) on $\mathrm{I}_{\mathrm{Ba}}{ }^{+2}$ of an opioid-sensitive cell. Step voltage protocols indicated above traces. Offscale capacity transients and tail currents have been truncated for clarity, and all inward currents were sensitive to block by $100 \mu \mathrm{M} \mathrm{Cd}^{2+}$, a calcium channel blocker (not shown).

b. A second, opioid-insensitive cell shows no response when opioid agonists were applied.

c. Scatter plot of 89 cells shows the linear correlation between the sizes of

DAMGO and dynorphin inhibition of $\mathrm{I}_{\mathrm{Ba}}{ }^{+2}$. Pearson Correlation Coefficient $=0.84$. Open symbols were collected in whole cell recording mode with voltage step protocols as in $\mathbf{a}$ and $\mathbf{b}$, and open symbols were collected in gramicidin perforated patch recording mode with voltage ramp protocols as described previously in methods and (Kyrozis and Reichling 1995). 
Figure 1. Rat sensory neurons respond identically to DAMGO and dynorphin

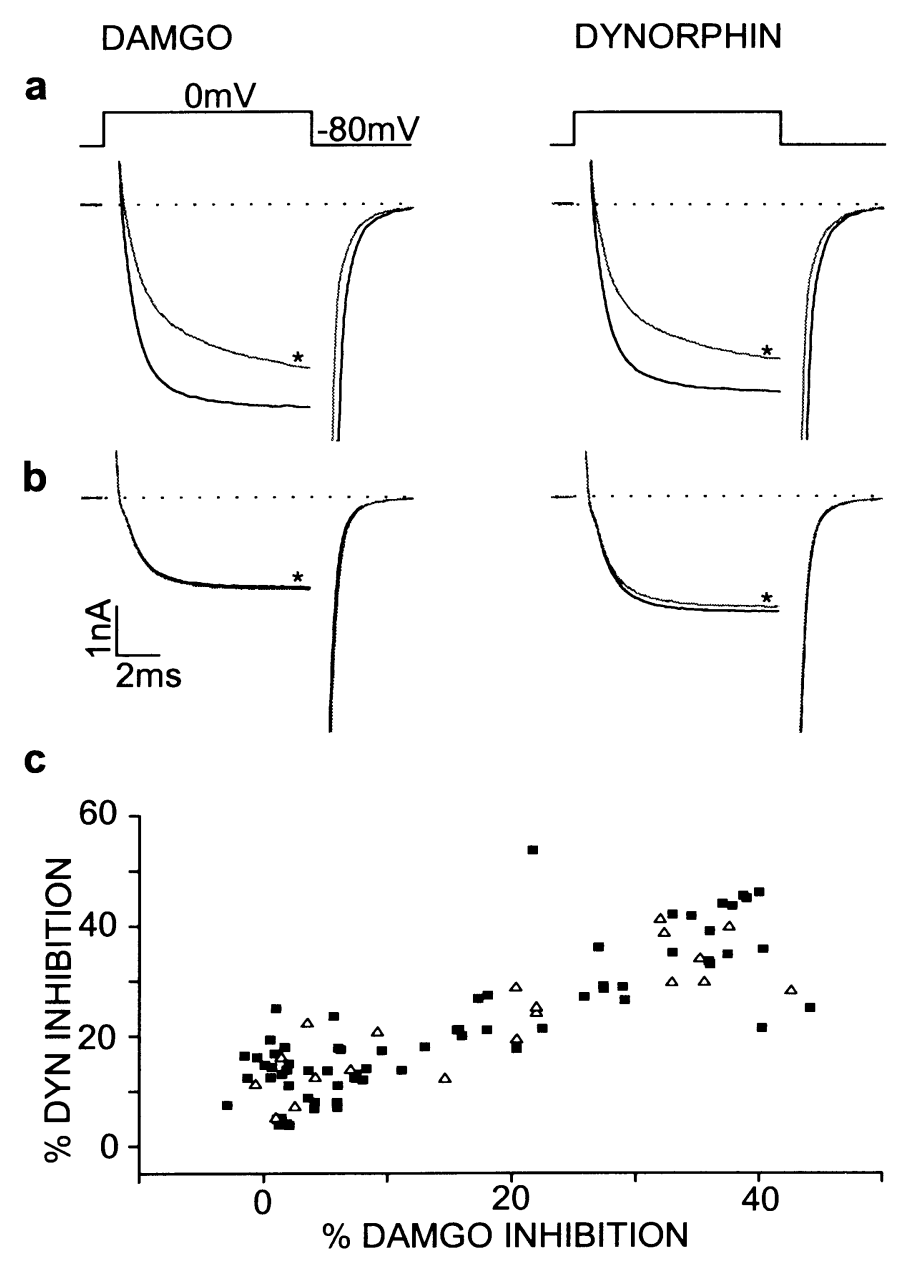




\section{Kappa Opioid Receptor mRNA is Rarely Found in Sensory Neurons}

As shown in figure 1, greater than ten percent inhibition of $\mathrm{I}_{\mathrm{Ba}}{ }^{2+}$ could be seen in response to DAMGO and dynorphin application to the majority of sensory neurons tested. In results chapter one of this thesis, we showed that nearly all sensory neurons that responded to DAMGO possessed detectable levels of MOR mRNA, and the concentration of the message clearly dictated the size of the DAMGO response on nociceptive (pain sensing) sensory neurons. This and a previous study in our lab have shown that DAMGO sensitivity appears to be under selective transcriptional control by factors related to sensory neuron size and in vivo modality (Taddese, Nah et al. 1995). Since so many DAMGO sensitive neurons also responded to the KOR opioid dynorphin, we sought to determine if similar mechanisms governed the expression of KOR by testing individual sensory neurons for their expression of KOR mRNA.

Figure 2 shows a representative gel with eight cells labeled A-H that were harvested for RT-PCR amplification of MOR and KOR mRNAs as in chapter one of the results section and in methods, with the exception that many of these cells were not recorded prior to harvest, nor were parallel amplifications of the housekeeping gene glyceraldehyde-3-phosphate dehydrogenase (GPD) done to quantify the levels of opioid receptor message that was amplified from each cell. Our aim in this study was simply to ask if KOR message was detectable in sensory neurons. In these experiments, part of a harvested neuron was used to probe for KOR mRNA, and the other part used to probe for MOR mRNA. Since the whole cell was harvested for each experiment, the reverse transcription reaction was carried out on the entire content of each harvested cell, and then the products of this reaction were split for two rounds of subsequent PCR. Nested 
primers directed at MOR and KOR sequences spanning introns insured that cDNAs encoding the two receptors were selectively amplified, and not genomic sequence. Known amounts of mutant poly $\mathrm{A}^{++}$mRNA encoding the target sequence plus an insert were added to each reaction tube to indicate the success of the reverse transcription (mutant bands). Sham reactions were also carried out for each round of RT-PCR, where a small amount of medium was drawn up into a separate harvest pipet in the vicinity of cultured neurons, the mutant RNA sequence added, and RT-PCR was done in parallel with the harvested cells and a calibration ladder that was constructed with known levels of mutant and synthetic wt sequence.

The lower, wild type (WT) series of bands indicates successful detection of the target sequence. Looking at the top gel, four out of the eight cells (lanes C, D, E, and F) have clearly visible levels of WT MOR mRNA, which matches the average count of nociceptor sensory neurons with detectable MOR message described in results chapter one. Comparison with the calibration ladder at left indicates that the cells are well within the range of our detection threshold, and the presence of mutant sequence in all lanes indicates that RT and PCR were successful.

We found only four out of 55 cells with detectable levels of KOR, a number far fewer than the number of cells which express sensitivity to dynorphin, DAMGO or MOR message in results chapter one. Figure 2 shows one such cell, in the WT lane F of the lower, KOR gel. 


\section{Legend, Figure 2}

MOR and KOR mRNA detected in individual sensory neurons. MOR and KOR mRNAs were amplified by RT-PCR and the limits of detection of the target sequences can be viewed relative to calibration ladders at left, to which known quantities of synthetic wt and mutant mRNA have been added. Control, sham-harvested reactions show no contaminating messages in the reaction.

Top Gel: MOR mRNA is detectable in the WT lane of cells C D, E, and F. Bottom Gel: Cell F, visible in the WT lane shows a rare expresser of KOR mRNA. 
Figure 2. Few cells contain KOR mRNA

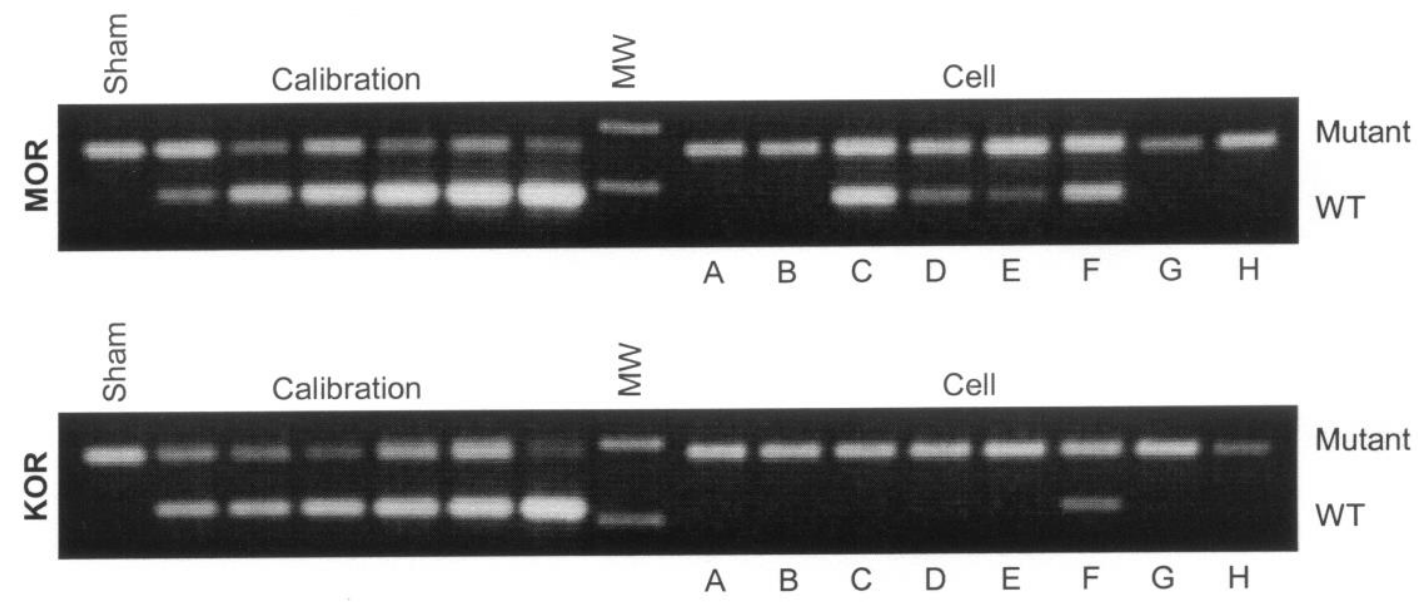




\section{CTAP Blocks the Responses to DAMGO and Dynorphin}

Two explanations could account for this mismatch between dynorphin response and KOR mRNA. The first would be that unlike MOR, KOR mRNA levels do not dictate the level of receptor expression, and that KOR receptor protein is somehow maintained despite levels of KOR message below our threshold for detection. The other explanation is that KOR is simply absent from most sensory neurons and that dynorphin is acting at another receptor. To see if dynorphin was exerting its effects on calcium channels through the MOR, we tested a low concentration $(200 \mathrm{nM})$ of the selective MOR peptide antagonist CTAP (Connor and Christie 1998) on opioid sensitive neurons, and asked if CTAP could block the effects of dynorphin.

Figure 3 shows examples and tabulated averages of the results from these experiments. Figure 3a shows inhibition of $\mathrm{I}_{\mathrm{Ba}}{ }^{2+}$ in response to $1 \mu \mathrm{M}$ DAMGO and dynorphin. The responses to both agonists were blocked by a five minute pre-application of $200 \mathrm{nM} \mathrm{CTAP}$, and the responses to both agonists recovered after washing the cell in control solution for 12-15 minutes. When we selected cells with $>15 \%$ inhibition by either peptide and then applied $200 \mathrm{nM}$ CTAP for five minutes, the responses to DAMGO $(n=15)$ and dynorphin $(n=17)$ were blocked. Since it is rare for HVA calcium currents on neurons to persist over such long time periods, we did not wait for recovery from CTAP block on every cell tested. Figure $3 \mathrm{~b}$ shows the summarized results of CTAP blockade of DAMGO responses and 3c shows the summarized results for CTAP block of dynorphin responses. Not all cells were tested for sensitivity to both peptides in this part

of the study, and repeated DAMGO or dynorphin applications regularly inhibited calcium currents over periods of five minutes or greater in the absence of CTAP, indicating that 
the responses did not simply disappear with repeated application. DAMGO and dynorphin responses were blocked to $<5 \%$ in CTAP (Figure 3, b and c). 


\section{Legend, Figure 3}

a. $\mathrm{I}_{\mathrm{Ba}}{ }^{2+}$ traces at selected time points during exposure to DAMGO and dynorphin in the presence and absence of CTAP, a specific MOR antagonist. Left column: DAMGO responses (top panel) and dynorphin responses (bottom panel) on an opioid sensitive neuron at the beginning of the experiment. Asterisks indicate the effect of the peptide on control currents. Middle column: DAMGO and dynorphin responses have been blocked by a five minute application of 200 nM CTAP. Righthand column: Both responses have returned after a 15 minute washout. Peak tail currents have been omitted for clarity. Cells were not included in this part of the study if they did not show significant (>15\%) inhibition by DAMGO or dynorphin.

b. and c. Average inhibition of $\mathrm{I}_{\mathrm{Ba}}{ }^{2+}( \pm \mathrm{SEM})$ by DAMGO (b) or dynorphin (c) in the absence and presence of 200 nM CTAP. Average inhibition by DAMGO on these cells was $23 \pm 3 \%, n=17$. Average inhibition by dynorphin was $23 \pm 4 \%, n=15$. Not all cells tested were monitored for recovery from CTAP block of opioid modulation. 
Figure 3. A selective MOR antagonist blocks the dynorphin response
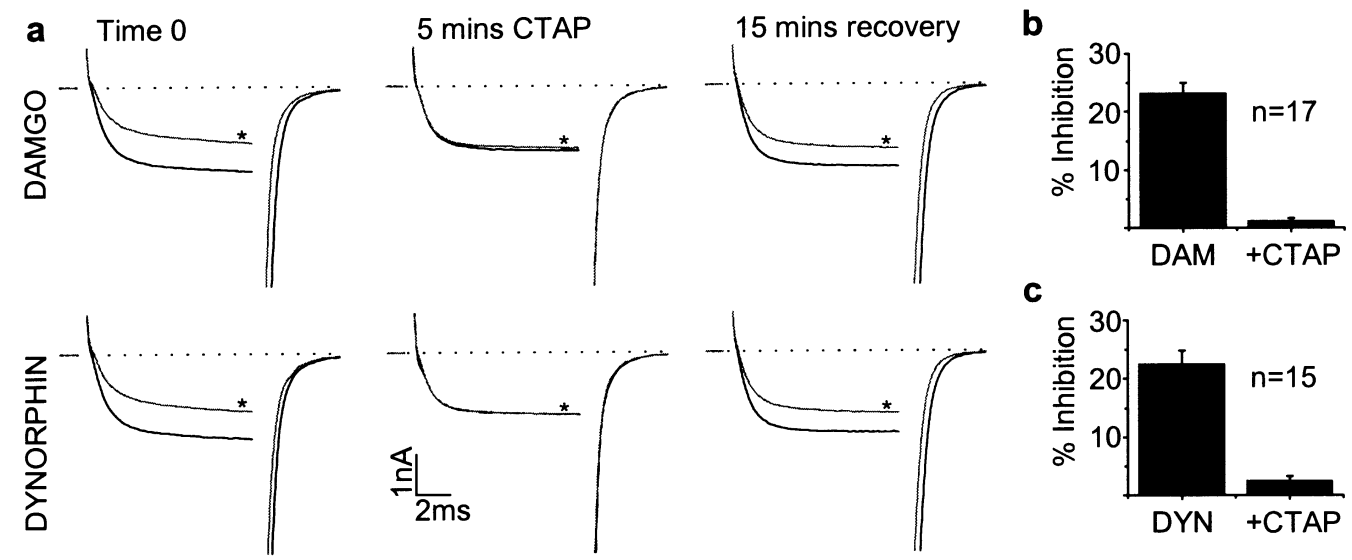

C

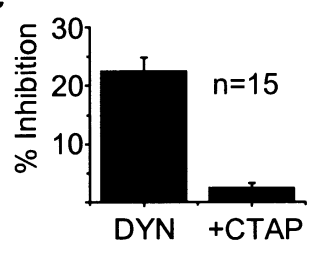




\section{Very Few Cells are sensitive to the KOR Agonist U-69593}

Given that cells were frequently sensitive to dynorphin, but rarely expressed KOR mRNA, we decided to look for KOR responses on sensory neurons using $1 \mu \mathrm{M} U-69593$, a specific KOR agonist (Lahti, Mickelson et al. 1985; Grudt and Williams 1993). We did not use the reported KOR agonist U-50488H because unlike U-69593, its actions are not fully reversible by naloxone (Hayes, Birch et al. 1988). Further, U-50488H directly blocks L-type calcium channels (Utz, Eckert et al. 1995), confounding the interpretation of previous work using it as a putative KOR agonist to modulate HVA calcium currents on sensory neurons (Moises, Rusin et al. 1994; King, Hall et al. 1999), 20-50\% of which is carried by L-type calcium channels (not shown).

Given the rare occurrence of KOR message expression found by RT-PCR, we had to search through many cells at random to look for sensitivity to U-69593. Interestingly, enriched populations of sensory neurons exhibiting "true" (NOR-BNI sensitive) KOR mediated inhibition of HVA calcium channels have been reported in colon afferents $(\mathrm{Su}$, Wachtel et al. 1998), but other studies with U-69593 have shown that few sensory neurons express sensitivity to this agonist (Borgland, Connor et al. 2001). In this study, it was shown that neurons with high levels of low voltage activated (T-type) calcium current are particularly insensitive to opioid modulation.

As shown in figure 1 and in results chapter one, close to $50 \%$ of dissociated sensory neurons are DAMGO sensitive or possess detectable levels of MOR, and identified nociceptors (Taddese, Nah et al. 1995) as well as randomly selected sensory neurons (Abdulla and Smith 1998) express a wide range of calcium channel inhibitions. We found that nearly every cell with a DAMGO response was also sensitive to dynorphin 
(Figure 1a). However, U-69593 inhibited $\mathrm{I}_{\mathrm{Ba}}{ }^{2+}$ in only 2/33 dynorphin-sensitive cells that we tested (Average dynorphin inhibition of $\mathrm{I}_{\mathrm{Ba}}{ }^{2+}$ on these cells was $26 \pm 7 \%$ ). U-69593 was applied first, and then dynorphin was applied. As in figure 3, if a cell did show greater than $15-20 \%$ inhibition of $\mathrm{I}_{\mathrm{Ba}}{ }^{2+}$ by dynorphin, then it was not included in the sample.

On the cells that responded to U-69593 and dynorphin, we tested for block of these two responses with the selective KOR antagonist NOR-binaltorphimine (NORBNI) (Portoghese, Lipkowski et al. 1987). Figure 4a shows a time course of the amplitude of $\mathrm{IBa}^{2+}$ from a rare U-69593 sensitive cell during drug and antagonist applications. Figure $4 \mathrm{~b}$ shows selected traces from this experiment. NOR-BNI entirely blocked the inhibition by U-69593, but only partially suppressed the actions of dynorphin, indicating that MOR was likely coexpressed with KOR on these rare U-69593 sensitive neurons. 


\section{Legend, Figure 4}

a. Time course of $\mathrm{I}_{\mathrm{Ba}}{ }^{2+}$ inhibition on a neuron that was sensitive to the KOR agonist U-69593. Open symbols refer to selected traces shown in $\mathbf{b}$, asterisks show where selected traces were taken, at peak inhibition of $\mathrm{I}_{\mathrm{Ba}}{ }^{2+}$. Break: A four-minute preapplication of $200 \mathrm{nM}$ NOR-BNI, a specific KOR antagonist, eliminated the U-69593 response, but only partially suppressed the dynorphin response.

b. Selected traces showing inhibition of $\mathrm{I}_{\mathrm{Ba}}{ }^{2+}$ by $1 \mu \mathrm{M}$ U-69593. Upper traces show U-69593 causing 37\%, then $35 \%$ inhibition of $\mathrm{I}_{\mathrm{Ba}}{ }^{2+}$ and dynorphin causing $55 \%$ inhibition of $\mathrm{I}_{\mathrm{Ba}}{ }^{2+}$ on this neuron. Lower traces show application of NOR-BNI completely blocking the action of U-69593, but only partially blocking the action of 1 $\mu \mathrm{M}$ dynorphin. Out of 33 dynorphin-sensitive cells tested with U-69593, only two showed responses to the KOR selective agonist, average response $34 \pm 4 \%$ SEM. 
Figure 4. A rare cell that responds to the KOR agonist U-69593
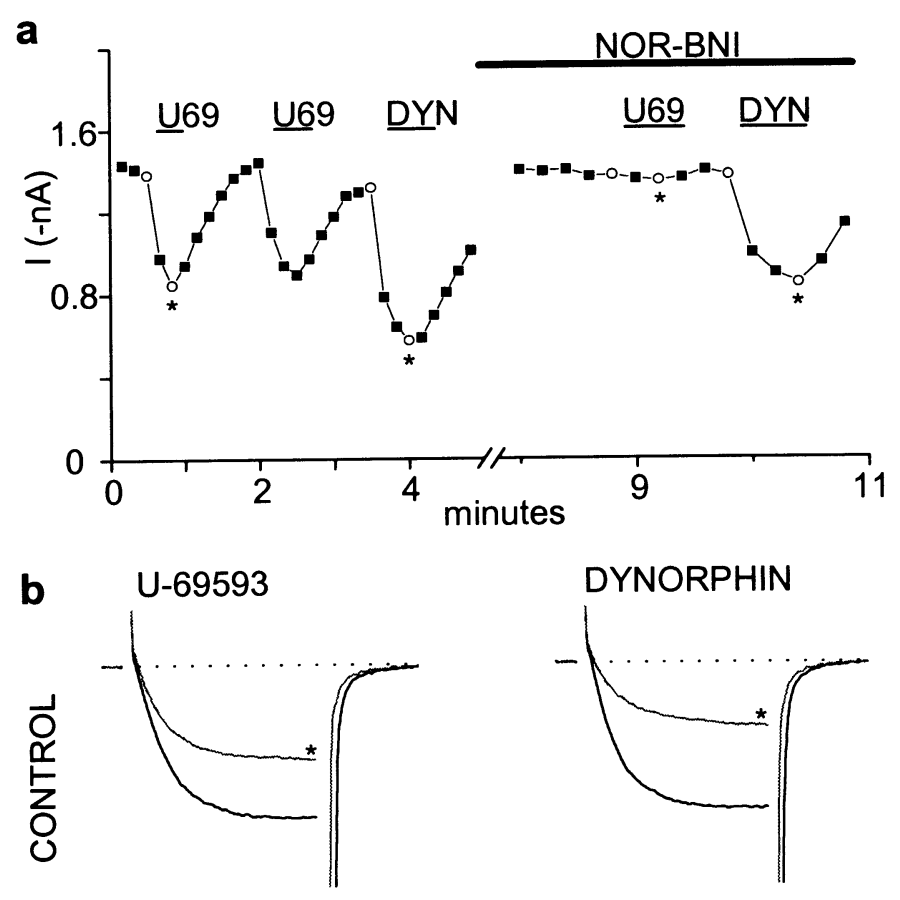

DYNORPHIN
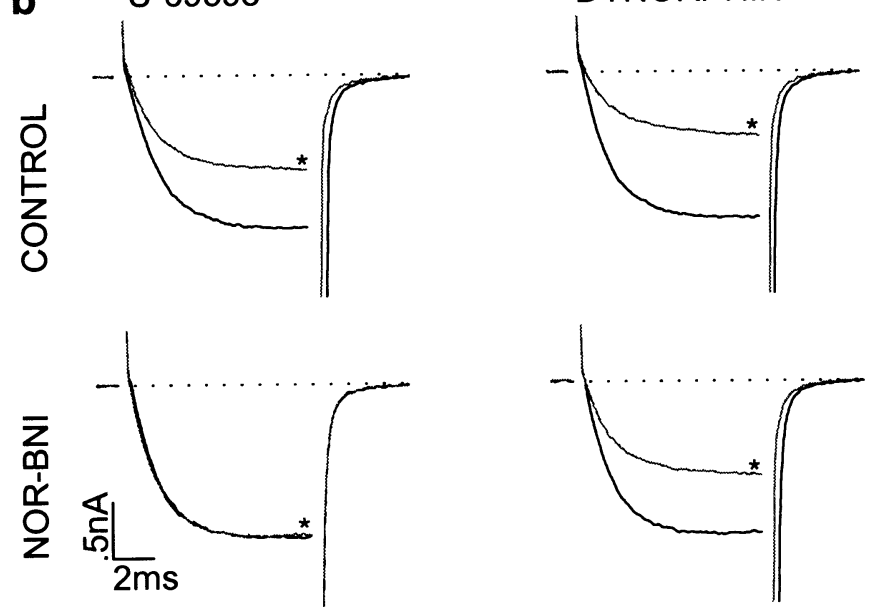


\section{Effects of MET- Enkephalin and Dynorphin on Neurons from the Locus Coeruleus}

In order to examine the effects of dynorphin in a system where MOR is the only opioid receptor that is expressed (Williams and North 1984), we compared the effects of met- enkephalin (ME) and dynorphin on neurons from rat locus coeruleus (LC) slices, where opioid agonists hyperpolarize cells through an increase in potassium conductance (Williams, Egan et al. 1982). ME was chosen because it is either washed away or quickly degraded following application (Williams, Christie et al. 1987). Consistent with our observations in dissociated sensory neurons, both ME and dynorphin resulted in hyperpolarizations, as shown in figure 5a. These responses were both diminished by preapplication of the MOR-selective antagonist CTAP but not by the KOR-selective antagonist NOR-BNI, suggesting that they are mediated by activation of MORs. (Figure $5 \mathrm{~b}$ and $\mathrm{c})$

Figure 5a also shows that a supramaximal concentration of the KOR selective agonist U-69593 has no effect, even though this dose is much larger than the reported $\mathrm{ED}_{50}$ of U-69593 on KORs in spinal cord slices, which is $23 \mathrm{nM}$ (Grudt and Williams 1993). NOR-BNI has been previously shown to selectively antagonize KOR-mediated hyperpolarizations by U-69593 in spinal cord neurons at concentrations higher than used in this study (Grudt and Williams 1993). 


\section{Legend, Figure 5}

a. Recording of membrane potential from an LC neuron in a slice preparation. ME elicited a hyperpolarization that was mimicked by dynorphin but not by the selective KOR agonist U-69593. The inset demonstrates the spontaneous oscillations characteristic of LC neurons. Plots adjacent to records in $\mathbf{b}$ and $\mathbf{c}$ show the average responses of at least three cells from different animals, expressed as the mean \pm SEM.

b. ME-induced hyperpolarizations $(-23 \pm 1.1 \mathrm{mV})$ are unaffected by the presence of NOR-BNI $(24.5 \pm 3.5 \mathrm{mV})$, but prevented by CTAP $(-6.3 \pm 4.8 \mathrm{mV})$.

c. Dynorphin-induced hyperpolarizations $(-21 \pm 1.1 \mathrm{mV})$ are unaffected by NORBNI $(15.3 \pm 1.7 \mathrm{mV})$, but prevented by CTAP $(1.7 \pm 0.9 \mathrm{mV})$. 
Figure 5. Dynorphin-induced hyperpolarization of LC neurons is mediated by MOR
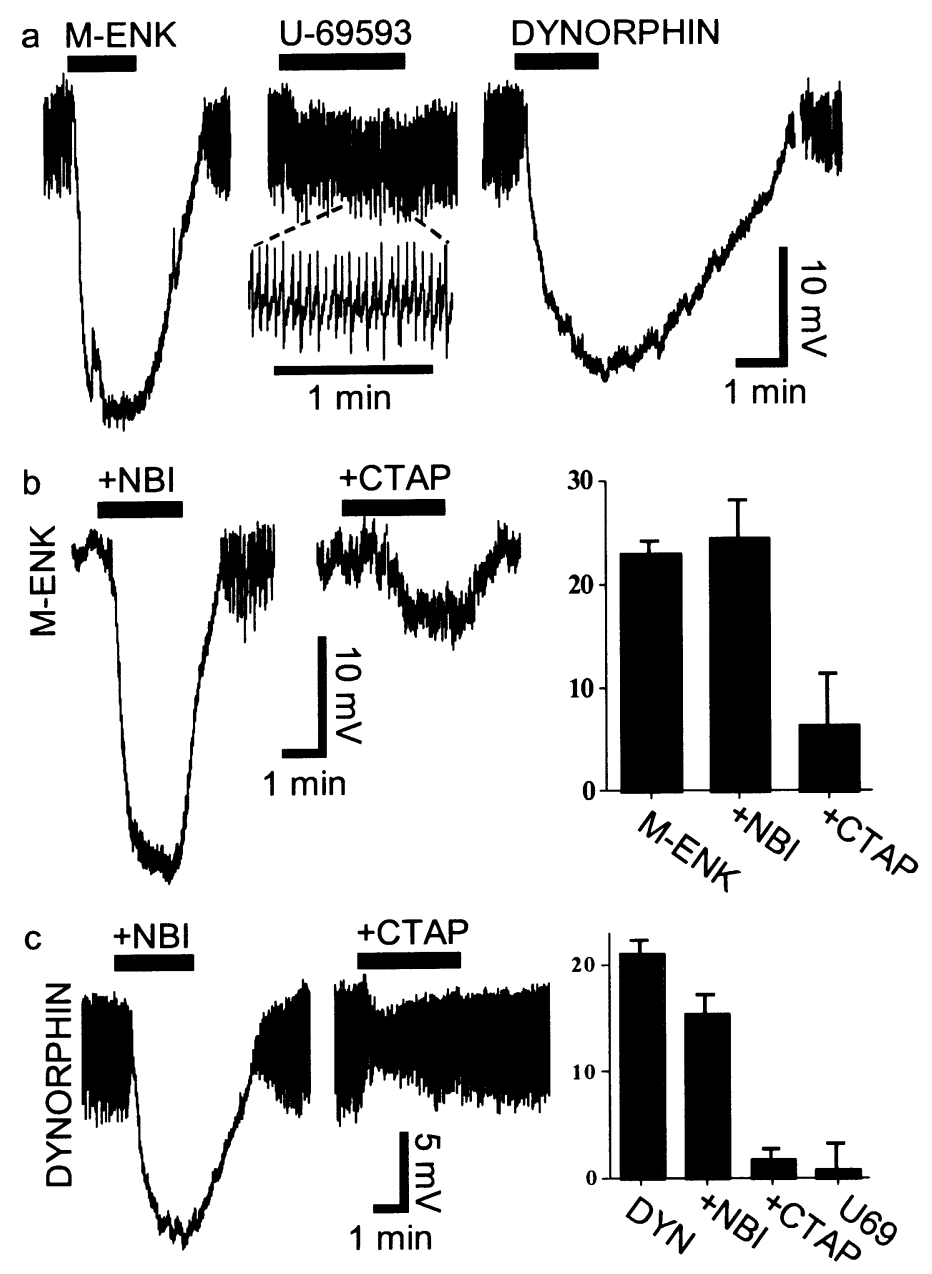


\section{Summary, results chapter II}

In order to ask which opioid receptors are expressed by sensory neurons, we used agonists for MOR and KOR on many cells to study the modulation of calcium channels and found a variety of responses to the two agonists. In previous work with the delta opioid receptor (DOR) agonist DPDPE, no responses were seen, but we saw many cells with identical responses to the MOR and KOR agonists, DAMGO and dynorphin. However, when we used an RT-PCR assay for KOR expression on dynorphin sensitive sensory neurons, we found that very few of them expressed detectable levels of KOR mRNA. Using a series of highly selective agonists and antagonists, we showed that dynorphin was exerting its effects on sensory neurons through the MOR, and that expression of MOR alone was sufficient to render cells sensitive to dynorphin, since it could stimulate MOR activation of potassium conductances on locus coeruleus neurons, where no KOR is expressed. 


\section{Discussion}

\section{Discussion I. MOR control of opiate analgesia}

Opiates suppress pain without affecting other sensations and they relieve pain persisting from past injuries without eliminating the protective response to, or knowledge of, a new injury (Jurna and Heinz 1979; Price, Von der Gruen et al. 1985; Cooper, Vierck et al. 1986; Yeomans, Pirec et al. 1996; Light and Willcockson 1999). The following findings indicate that sensory modality-selective expression of MOR mRNA contributes to both aspects of opiate specificity: 1) MOR activation inhibits $\mathrm{Ca}^{2+}$ channels on most nociceptors, but not on any non-nociceptive mechanosensors; 2) Many nociceptors express mRNA for MOR, but mechanosensors do not; 3) MOR mRNA levels differ widely among different nociceptors, limiting $\mathrm{Ca}^{2+}$ channel inhibition when MOR mRNA is below $15 \mathrm{pM}$; 4) The vast majority of nociceptors with large cell bodies - those likely to be myelinated and to mediate antinociceptive reflexes and the initial sensation of pain-express MOR mRNA below $15 \mathrm{pM}$ and have lower opioid sensitivity; 5) Small nociceptors - those likely to be unmyelinated and to mediate persisting pain — are more likely to express MOR mRNA at higher levels and to have maximal opioid sensitivity. The conclusion of low MOR mRNA in large nociceptors is based not only on its concentration but also on its expression relative to another gene. Specifically, the number of MOR mRNA molecules drops in the largest nociceptors whereas the number of GPD mRNA systematically increases with increasing size.

The differences between small and large nociceptors are not black and white because individual cells in both groups can either fail to express MOR or can express the mRNA at high levels. Among small nociceptors, there is a wide range of different MOR 
mRNA levels and opioid sensitivities, and many are insensitive. In comparison, large nociceptors are only slightly more likely to fail to express MOR mRNA, but, if they have it, they usually express it at low levels, and have correspondingly low responses to DAMGO. Small and large nociceptors appear to differ in their probability of high MOR mRNA expression, and this leads to a low average opioid sensitivity of large nociceptors. The fact that many nociceptors, including small ones, do not express MOR mRNA at levels that cause maximal opiate sensitivity suggests that up-regulating MOR gene transcription could be a potential therapeutic strategy for increasing the efficacy of opiate analgesia.

MOR mRNA expression appears to be controlled in two different ways. One functions like a simple on-off switch. Turned on only in nociceptors, it causes opioids to inhibit pain while sparing other sensations. The other functions like a dimmer switch that regulates MOR mRNA concentration, and thereby distinguishes nociceptors of different size. The dimmer can be set at many levels in small nociceptors: many do not express MOR mRNA, and those having it are about as likely to express above $15 \mathrm{pM}$ (the saturated range) as not (Figure 1A below). If the dimmer were turned down, this would shift some low expressers to become non-expressers and some high expressers to become low; this describes the relation of large nociceptors to small. Such a dimmer switch might be made by interplay of transcriptional promoters and repressors (Yuh, Bolouri et al. 1998) or by selective RNA stabilization (Wymore, Negulescu et al. 1996). Our results do not demonstrate a mechanism. Rather, they demonstrate a functional purpose for finetuning the MOR mRNA level: it contributes to the ability of opioids to inhibit persistent pain more than the initial pain of an injury. The data suggest the hypothesis in Figure 1B, 
which assumes that MOR protein levels in presynaptic membranes parallel the mRNA levels measured at the cell bodies. This would make presynaptic terminals formed by unmyelinated nociceptors more susceptible to opiates than those of myelinated nociceptors, thereby contributing to the greater opioid sensitivity of second pain. 


\section{Legend, Figure 1}

A. The average concentration $( \pm$ SEM) of MOR mRNA for different sized tooth pulp afferents in which it was detectable (black, left axis). The hatched right axis shows the fraction $( \pm 68 \%$ confidence interval) of tooth pulp afferents in each size bin that had detectable MOR mRNA at levels above $15 \mathrm{pM}$, the concentration below which opioid sensitivity is sub-maximal (Figure 6, results chapter one). $80 \%$ of large nociceptors that express MOR mRNA express below $15 \mathrm{pM}$.

B. Hypothesis for selective opioid suppression of second pain. If protein levels at presynaptic terminals correspond to mRNA levels at the cell body, then MOR is absent from virtually all non-nociceptive terminals and is present at low levels at terminals of most myelinated nociceptors. Thereby, second pain, which is mediated by the unmyelinated terminals rich in MOR, is more sensitive to opiate inhibition than first pain, and non-pain sensations are insensitive. 
Figure 1. Most Large Nociceptors Are RNA-Limited

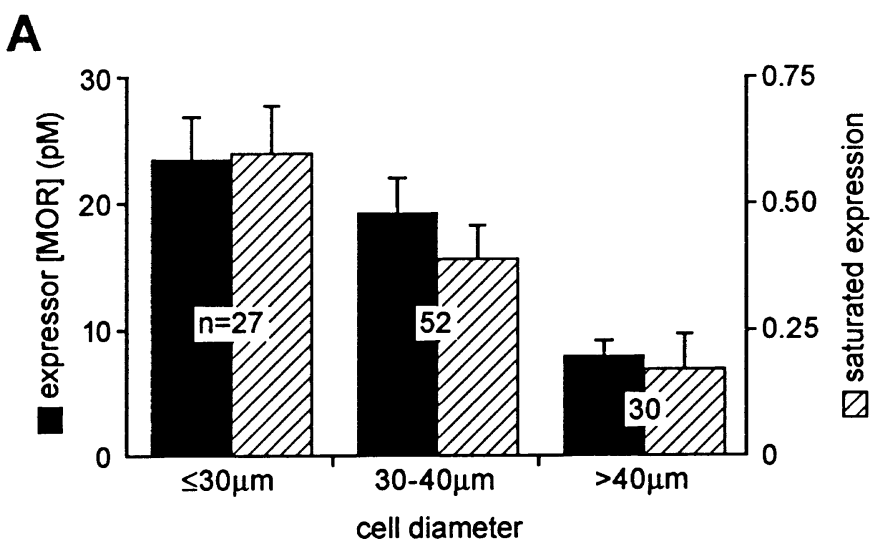

B
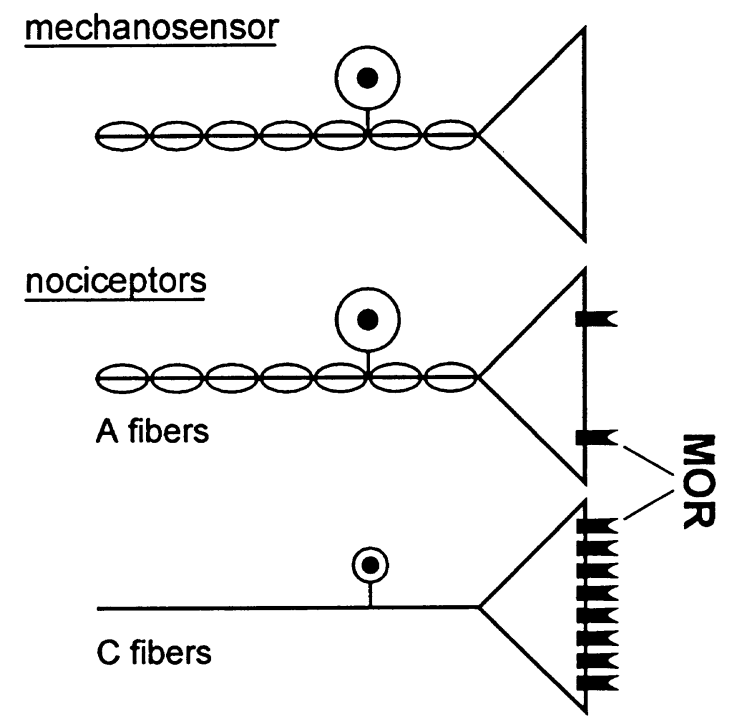


\section{Unanswered Questions}

Our results do not address two important aspects of opioid specificity: the high opioid sensitivity of summated pain and long-term changes in opioid efficacy. Unlike first pain and most other sensations that diminish when there are successive stimuli, second pain increases in intensity (Price, Hu et al. 1977) and the antinociceptive withdrawal reflex is enhanced (Wall and Woolf 1984). This summated second pain responds to even lower opiate concentrations than does acute second pain (Price, Von der Gruen et al. 1985; Woolf and Wall 1986; Yeomans, Pirec et al. 1996). This cannot be explained by genetic differences between sensory neurons, but must be a property of neural circuitry and/or stimulation-dependent opioid plasticity. The endogenous pain control circuit responds to pain by releasing opioid peptides into the spinal cord, and it can itself be triggered by opiates (Fields 1987). These properties could allow it to provide to an animal heightened opiate sensitivity following conditioning noxious stimuli. Another possible contributor would be activity-dependent recruitment of presynaptic delta opioid receptors; this is suggested by the presence of delta receptors in a subset of synaptic vesicles but not on the surface membrane of sensory neurons (Zhang, Bao et al. 1998). Finally, postsynaptic opioid actions (Grudt and Williams 1994; Trafton, Abbadie et al. 1999) are not considered here. Postsynaptic MOR might be important for opioid selectivity for summated second pain, but are likely unimportant for distinguishing between myelinated and unmyelinated inputs because these synapse upon the same postsynaptic cell.

Long-term changes in opioid efficacy occur during neurogenic pain and opiate addiction. Neurogenic pain - a condition of heightened pain sensitivity following nerve 
damage - is relatively resistant to opioid analgesia, a serious clinical problem (Arner and Meyerson 1988; Iadarola and Caudle 1997). Abdulla and Smith (Abdulla and Smith 1998) found decreased opioid inhibition of sensory neuron $\mathrm{Ca}^{2+}$ channels when animals had undergone nerve damage, suggesting the possibility of decreased opioid receptor expression. Alternatively, opioid efficacy could be inhibited through modulation of the receptor, such as occurs when protein kinase $\mathrm{C}$ diminishes $\mathrm{G}$ protein coupling to $\mathrm{Ca}^{2+}$ channels (King, Hall et al. 1999). Tolerance - a decreased efficacy of the drug-is a hallmark of prolonged opiate use. Decreased expression, desensitization, or inhibitory modulation of opioid receptors might contribute to tolerance (Whistler, Chuang et al. 1999; Samoriski and Gross 2000), although much evidence suggests that prolonged opiate use evokes a separate signaling path that counters opiates by enhancing excitability in opiate sensitive synapses (Williams, Christie et al. 2001).

\section{The Necessity Of Quantitative PCR}

Detecting the difference in MOR mRNA between nociceptive and nonnociceptive neurons did not require quantitative PCR, but the distinction between different nociceptors did. Technical limitations generally preclude quantitative measure of transcription in neurons, yet it is often fundamental to the function of a protein. Among the best examples is Endo 16, a gene that codes for a secretory protein important in sea urchin development. The Endo 16 regulatory system consists of a large array of DNA binding proteins and upstream promoting/repressing DNA sequences that, in various combinations, generate precise changes in transcription rate (Yuh, Bolouri et al. 1998). Most of the machinery is devoted to fine control of transcription rate and only a small fraction controls the site where transcription occurs in the animal (Yuh and 
Davidson 1996). The methods generally used in neurobiology to detect gene transcription in individual cells—in situ hybridization and immunocytochemistry—can identify the anatomic location of gene expression, but do not quantify mRNA or protein levels. They would fail to detect the activity of the bulk of the control machinery for Endo 16.

Quantitative single cell PCR circumvents this limitation. In our case, we determined the absolute amount of mRNA through a modification of competitive PCR that included a measure of reverse transcription efficiency. Jonas et al. (Jonas, Racca et al. 1994) used a relative method to show that the proportion of transcripts for different channel subtypes explains variations in glutamate receptor kinetics in different hippocampal neurons. Baro et al. (Baro, Levini et al. 1997) counted the absolute levels of Shal $\mathrm{K}^{+}$channel mRNA in individual lobster neurons and showed that Shal, not Shaker, gene expression determines $\mathrm{K}^{+}$current amplitude. Tkatch et al. (Tkatch, Baranauskas et al. 2000) used a null method to show that the level of cDNA for Kv4.2 determines the different amplitudes of inactivating $\mathrm{K}^{+}$channel current in different cell types of basal ganglia. These investigations provide examples where transcript level predicts its respective protein level, and also determines a functional distinction between different types of neurons. Our experiments imply that precise control of a particular mRNA in individual cells can contribute to a complex trait, the ability of opioids to suppress pain from a past injury without blocking pain from a new injury. Together, these studies emphasize the importance of quantifying gene transcription in individual neurons, a technique now more accessible with the advent of automated real-time, fluorescence monitoring of cDNA levels during PCR (Heid, Stevens et al. 1996). 


\section{Future directions I. MOR control of opiate analgesia}

This page is written as a brief sketch of potential experiments that could be done to further the findings reported above. It is written in the fashion of a specific aims page, with suggestions for practical experiments.

1) Cloned opioid receptors have been put into genetically engineered vaccinia virus in order to study the processes of receptor coupling, desensitization, and downregulation in heterologous systems, as well as native tissues (C. Evans at UCLA, personal communication). In order to test the theory that MOR mRNA levels dictate opiate sensitivity, we suggest using such a delivery method to put different amounts of MOR into non-nociceptive neurons or neurons from MOR knockout mice, so that we might titer MOR mRNA levels against the opioid response as seen in native expressers. This might underlie work toward a potential genetic therapy approach to pain treatment.

2) Using the method of quantitative RT-PCR, we could ask if the decreased sensitivity to MOR agonists seen by seen by Abdullah following axotomy (Abdulla and Smith 1998) can be explained by observable changes in MOR message levels.

3) Sensory neuron phenotype is set during development by a combination of external cues and the genetically programmed expression of specific molecules. We have proposed that nociceptors exert variable control of opiate sensitivity, while nonnociceptors have this control mechanism switched off. Using patch clamp, we might examine sensory neuron progenitor cells from the neural crest, looking for the onset of opiate sensitivity. In order to identify putative elements that control whole families of nociceptor-specific molecules, it may be useful to examine the expression profiles of these cells with RT-PCR. 


\section{Discussion II. Dynorphin activation of MOR}

We have shown two results in native cell preparations that are consistent with previous observations by ours and other laboratories. They are 1) that dynorphin sensitivity is often expressed by sensory neurons (Moises, Rusin et al. 1994; Wilding, Womack et al. 1995; King, Hall et al. 1999) and 2) that dynorphin can functionally signal through the MOR (Chavkin, Henriksen et al. 1985; Zhang, Tong et al. 1998). In contrast to the reports of dynorphin modulation of sensory neurons by KOR, our findings point to a mechanism that does not involve the KOR, but implies that MOR as a potential mediator of dynorphin actions on most sensory neurons.

Dynorphin stimulation of the MOR was seen in two entirely unrelated tissues, the LC and the DRG, and could be observed as a function of both calcium channel inhibition and potassium channel activation. Therefore, dynorphin sensitivity of the MOR was independent of cellular identity or the effector system that was targeted by MOR. This result bears out a prediction made with cloned receptors in heterologous expression systems (Zhang, Tong et al. 1998), that MOR is potentially a target for dynorphin in vivo. It also speaks to a large body of cellular and behavioral data that tells us that dynorphin often has actions outside of KOR stimulation, including the activation of postsynaptic NMDA channels (Caudle and Isaac 1988), resulting in neurotoxicity in cultured hippocampal neurons (Caudle and Dubner 1998) and hyperalgesia in intact animals (Vanderah, Gardell et al. 2000; Wang, Gardell et al. 2001).

The obvious implications for this result are twofold: First, it means that the scientific community at large should carefully reconsider current and published results from experiments in which the opioid (naloxone reversible) effects of dynorphin are 
thought to be mediated by KOR. In the spinal cord, dynorphin's excitatory postsynaptic effects have been previously ascribed to disinhibition of tonic blockade by opioid sensitive GABAergic and glycinergic neurons in the dorsal horn (Randic, Kolaj et al. 1995). However, these effects may not be mediated by KOR. MOR is widely expressed on these neurons (Arvidsson, Riedl et al. 1995), though in fact the majority of KOR seen in the spinal cord is postsynaptic (Arvidsson, Riedl et al. 1995). Our result supports this observation, that KOR is rarely expressed by presynaptic sensory afferents, and dynorphin may be able to block transmitter release from any cell expressing MOR on presynaptic terminals.

Second, this finding speaks to a growing literature on the chemical identity of select sensory neuron populations. The selective expression of neuropeptides and their receptors (Elde, Arvidsson et al. 1995; Woolf 1996), voltage gated sodium channels (Waxman, Cummins et al. 1999) and sensory transduction channels (McCleskey and Gold 1999) by primary afferents is being demonstrated with a variety of assays. Colon sensory afferents have been shown to be insensitive to MOR and DOR agonists, but enriched in cells that are sensitive to KOR agonists ( $\mathrm{Su}$, Wachtel et al. 1998), a result which is thought to explain how KOR agonists are particularly effective at relieving visceral pain (Su, Sengupta et al. 1997; Sengupta, Snider et al. 1999). Thus, while the present study refutes earlier reports from our lab and others that KOR might be widely expressed by sensory neurons, its expression is likely under the control of factors that are specific to visceral function, and not under the same transcriptional control as MOR, whose mRNA is expressed at detectable levels in the majority of sensory neurons. 


\section{Future directions II. Dynorphin stimulation of MOR}

Again, this page is written in the style of a specific aims page, with brief descriptions of experiments that might further explore the findings reported above.

1) Clearly, dynorphin can activate the MOR in vitro, and there is certainly potential for interaction between dynorphin and MOR in vivo, especially in conditions of dynorphin upregulation, for instance following nerve injury or chronic opiate administration. It would be important to identify the functional implications of this possibility, perhaps first by demonstrating ways that MOR might be able tell the difference between endogenous ligands in the context of nerve injury or chronic use of narcotics. Using patch clamp analysis, we may be able to identify differences in the desensitization induced by the two agonists, or we may be able to induce agonist-specific changes in coupling and efficacy that come with prolonged exposure.

2) Another way to look for the functional implications of MOR activation by dynorphin might be found in examination of central neurons from locus coeruleus (Ingram, Wilding et al. 1997), or spinal cord (Grudt and Williams 1994) where MOR couples to both HVA calcium channel inhibition as well as voltage gated potassium channel activation. In locus coeruleus, partial agonism of MOR by morphine appears to cause preferential stimulation of calcium channel inhibition, which is the effector most tightly coupled to MOR activation. We could do patch clamp analysis of spinal cord neurons to ask if DAMGO and dynorphin vary in their efficacy at stimulating these two pathways. Agonist-specific coupling has been described in the adrenergic system, where noradrenaline and octopamine stimulate alpha-2 adrenergic receptors (Rudling, Richardson et al. 2000) to activate different effector pathways, depending on agonist. 


\section{Summary and Conclusions}

In chapter one of the results section, we saw how nociceptors control their opioid sensitivity, and we described a mechanism for how opiates are able to suppress pain without affecting other sensations, so that normal reflex pathways and the ability to sense new injuries remain intact during convalescence. We accomplished this by using electrophysiology in combination with a novel, quantitative RT-PCR method that allowed us to measure the messenger RNA encoding the mu opioid receptor in single sensory neurons of identified modality, after recording from them in a tissue culture dish. Using the inhibition of high voltage activated calcium channels as an assay for cellular excitability, we found that nociceptors express a wide range of opioid sensitivities, and non-nociceptive muscle spindle afferents and fine touch mechanosensors are insensitive to opioids. When we performed RT-PCR on recorded nociceptors and non-nociceptors to probe for mu receptor mRNA, we found that most nociceptors express detectable levels of mu-opioid receptor message. In contrast, the vast majority of non-nociceptive sensory neurons patently lacked RNA encoding the mu opioid receptor. This told us that the pain relief derived from the therapeutic administration of analgesic doses of the mu opioid receptor agonist morphine could be explained by the selective inhibition of nociceptive neurons.

Further, we found that the degree of electrical block of nociceptor excitability by the mu opioid receptor agonist DAMGO in any given cell was dependent on its levels of mu opioid receptor mRNA, and that there was a threshold concentration of mu opioid receptor mRNA that is required for a cell to be opioid sensitive, about $15 \mathrm{pM}$.

Nociceptors that contain mu opioid receptor mRNA in excess of this concentration are far 
more likely to be opioid sensitive than nociceptors which contain concentrations below $15 \mathrm{pM}$. The correlation between the concentration of mu opioid receptor mRNA and electrical block by opioids was most pronounced in small to medium size neurons, where concentrations above $15 \mathrm{pM}$ were much more common than found in large cells, and the size of the opioid block of calcium channels was greatest. In these cells, the amount of mu opioid receptor mRNA clearly dictated the amount of inhibition in a saturable relation (Figure 6, results chapter one). Large cells, if they did contain mu opioid receptor mRNA, were most likely to express it at concentrations less than $15 \mathrm{pM}$, and showed small or undetectable levels of calcium channel modulation by mu opioid receptor agonists. Cells of all sizes, nociceptors or otherwise, possessed similar levels of the calcium channel targeted by opioids on sensory neurons. A second mRNA species encoding a metabolic enzyme that was amplified in parallel with the message for mu opioid receptor as a control showed a linear increase with cell size. Thus, the lack of opioid sensitivity seen in large cells seems to be linked to the specific regulation of mu opioid receptor message and not the result of an absence of targeted channels or any general change in mRNA concentration accompanying cell size.

This result explains for us how fast-transmitting pain and nociceptive reflex signals conveyed along the axons of large diameter nociceptor sensory neurons are spared when opioids are present, while the slowly transmitting, lasting pain signals conveyed along the axons of small diameter nociceptors are blunted, and bears out clinical observations of patients and human subjects under morphine analgesia. Whether the analgesia is accomplished with morphine or the release of endogenous opioids in response to a major injury, the overwhelming pain of the tissue damage is suppressed, but 
the pain of a pinprick or a new injury is still detected. Complete block of all sensation is a poor treatment for pain relief, as can be observed by anyone who has bitten the inside of their cheek after a shot of novocaine at the dentist's office. No pain is registered, but the taste of blood is a quick enough informer that an injury has taken place. One must be able to sense injury at all times.

In chapter two of the results section, we observed that another subtype of opioid receptor, the kappa opioid receptor, is expressed much less often on sensory neurons than previously reported. Our initial findings agreed with those published by our lab and others, that like the mu opioid receptor agonist DAMGO, many cells are also sensitive to dynorphin, a classical kappa opioid receptor agonist and endogenous opioid peptide found throughout the spinal cord and central nervous system. Dynorphin inhibits high voltage activated calcium channels on sensory neurons through a G-protein coupled receptor the same way that DAMGO or the endogenous mu opioid receptor agonist metenkephalin inhibits calcium channels, and we found what appeared to be a striking correlation between the magnitude of DAMGO and dynorphin responses on sensory neurons. At first, we took this to mean that there was very tight co-expression of the two opioid receptor subtypes, which would have been really interesting in light of the findings in chapter one, as well as recent work proving that heteromultimerization could be observed between cloned opioid receptors in heterologous systems, giving rise to multimeric receptors with unique pharmacologies. It made sense to us that another opioid receptor subtype was regulated like the mu opioid receptor, and it would prove a perfect system for studying the heteromultimerization of opioid receptors on a native tissue. However, when we used our RT-PCR tools to probe for the expression of kappa 
opioid receptors on sensory neurons, we found that very few indeed expressed measurable levels of kappa opioid receptor message. This meant that either kappa opioid receptor message is regulated differently than mu opioid receptor, i.e. message levels do not determine sensory neuron vulnerability to kappa agonists, or that dynorphin exerts its effects on sensory neurons through another receptor, quite possibly the mu opioid receptor. The second possibility was in best keeping with the mechanism we described for the regulation mu opioid receptor expression, and so we embarked on a pharmacological study of dynorphin's actions on sensory neuron excitability, to see if this prototypic kappa opioid receptor agonist could be a mu receptor agonist as well.

First, we used antagonists that were selective for mu opioid receptors to block dynorphin inhibition of calcium channels. This was effective on all cells tested, at very low concentrations of antagonist. Therefore, dynorphin was in fact acting at mu opioid receptors on the vast majority of sensory neurons. Second, since we observed a few sensory neurons with measurable levels of kappa opioid receptor, we used a more highly selective kappa opioid receptor agonist, U-69593, to look for "true" kappa opioid receptor mediated responses on dynorphin-sensitive sensory neurons. This proved nearly fruitless except for two out of more than thirty dynorphin sensitive cells tested. These two were sensitive to U-69593. A selective kappa opioid receptor antagonist blocked the effects of U-69593 on these cells, leaving intact a large portion of the inhibition effected by dynorphin, which was likely mediated through the mu opioid receptor. Finally, we wished to ask if there was something unique about the mu opioid receptors expressed on sensory neurons, perhaps rendering them sensitive to dynorphin as a consequence of their locale of expression. So we tested the actions of dynorphin in another well-established 
system, the locus coeruleus, where mu opioid receptors are the only opioid receptor expressed, and they couple to a different effector system than in sensory neurons, an increase in potassium conductance. By measuring the opioid-induced hyperpolarization of locus coeruleus neurons, we found that dynorphin modulated locus coeruleus neurons in much the same manner it modulated sensory neurons: that is, a mu opioid receptor antagonist could block its effects, the kappa opioid receptor agonist U-69593 did nothing, and the selective kappa opioid receptor antagonist did not block the effect. Thus, independent of the tissue or the second messenger system, dynorphin stimulates the mu opioid receptor in a manner similar to other endogenous agonists.

This finding speaks to a growing literature on the actions of dynorphin within the central nervous system that have nothing to do with kappa opioid receptors. Results very similar to this were recently described using the expression of opioid receptors in heterologous systems, where dynorphin could be made to inhibit the production of cyclic nucleotides with similar potency through the stimulation of any of the three opioid receptor subtypes. Our results in native tissues bear out the prediction made in that paper, that dynorphin may be an endogenous agonist at mu opioid receptors in vivo, especially in conditions where dynorphin levels are upregulated. The consequences of this are as yet unknown, but clues might be found in studying the kinetics and mechanisms of mu opioid receptor desensitization that come with long term exposure to dynorphin compared with other opioid receptor agonists. 


\section{References}

Abdulla, F. A. and P. A. Smith (1998). "Axotomy reduces the effect of analgesic opioids yet increases the effect of nociceptin on dorsal root ganglion neurons." J Neurosci 18(23): 9685-94.

Acosta, C. G. and H. S. Lopez (1999). "delta opioid receptor modulation of several voltage-dependent $\mathrm{Ca}(2+)$ currents in rat sensory neurons." J Neurosci 19(19): 8337-48.

Aguayo, L. G. and G. White (1992). "Effects of nerve growth factor on TTX- and capsaicin-sensitivity in adult rat sensory neurons." Brain Res 570(1-2): 61-7.

Ahlquist, M. L., L. G. Edwall, et al. (1984). "Perception of pulpal pain as a function of intradental nerve activity." Pain 19(4): 353-66.

Ahlquist, M. L., O. G. Franzen, et al. (1986). "The relation between intradental nerve activity and pulpal pain after heat stimulation." Acta Physiol Scand 127(1): 1-7.

Akil, H., D. J. Mayer, et al. (1976). "Antagonism of stimulation-produced analgesia by naloxone, a narcotic antagonist." Science 191(4230): 961-2.

Akins, P. T. and E. W. McCleskey (1993). "Characterization of potassium currents in adult rat sensory neurons and modulation by opioids and cyclic AMP." Neuroscience 56(3): 759-69.

Arner, S. and B. A. Meyerson (1988). "Lack of analgesic effect of opioids on neuropathic and idiopathic forms of pain." Pain 33(1): 11-23.

Arvidsson, U., M. Riedl, et al. (1995). "Distribution and targeting of a mu-opioid receptor (MOR1) in brain and spinal cord." J Neurosci 15(5 Pt 1): 3328-41. 
Arvidsson, U., M. Riedl, et al. (1995). "The kappa-opioid receptor is primarily postsynaptic: combined immunohistochemical localization of the receptor and endogenous opioids." Proc Natl Acad Sci U S A 92(11): 5062-6.

Barnes, W. M. (1992). "The fidelity of Taq polymerase catalyzing PCR is improved by an N-terminal deletion." Gene 112(1): 29-35.

Baro, D. J., R. M. Levini, et al. (1997). "Quantitative single-cell-reverse transcriptionPCR demonstrates that A-current magnitude varies as a linear function of shal gene expression in identified stomatogastric neurons." J Neurosci 17(17): 6597610.

Basbaum, A. I. and H. L. Fields (1984). "Endogenous pain control systems: brainstem spinal pathways and endorphin circuitry." Annu Rev Neurosci 7: 309-38.

Bean, B. P. (1989). "Neurotransmitter inhibition of neuronal calcium currents by changes in channel voltage dependence." Nature 340(6229): 153-6.

Beecher, H. (1946). "Pain in men wounded in battle." Ann Surg 123: 96-105.

Benson, C. J., S. P. Eckert, et al. (1999). "Acid-evoked currents in cardiac sensory neurons: A possible mediator of myocardial ischemic sensation." Circ Res 84(8): $921-8$

Berntson, G. G. and J. M. Walker (1977). "Effect of opiate receptor blockade on pain sensitivity in the rat." Brain Res Bull 2(2): 157-9.

Bevan, S. and J. Winter (1995). "Nerve growth factor (NGF) differentially regulates the chemosensitivity of adult rat cultured sensory neurons." J Neurosci 15(7 Pt 1): 4918-26. 
Borgland, S. L., M. Connor, et al. (2001). "Nociceptin inhibits calcium channel currents in a subpopulation of small nociceptive trigeminal ganglion neurons in mouse." $\underline{\mathbf{J}}$ Physiol 536(Pt 1): 35-47.

Bunzow, J. R., G. Zhang, et al. (1995). "Characterization and distribution of a cloned rat mu-opioid receptor." J Neurochem 64(1): 14-24.

Burgess, P. R. and E. R. Perl (1967). "Myelinated afferent fibers responding specifically to noxious stimulation of the skin." J. Physiol. 190: 541-562.

Buzas, B. and B. M. Cox (1997). "Quantitative analysis of mu and delta opioid receptor gene expression in rat brain and peripheral ganglia using competitive polymerase chain reaction." Neuroscience 76(2): 479-89.

Campbell, J. N. and R. H. LaMotte (1983). "Latency to detection of first pain." $\underline{\text { Brain Res }}$ 266(2): 203-8.

Caudle, R. M. and R. Dubner (1998). "Ifenprodil blocks the excitatory effects of the opioid peptide dynorphin 1-17 on NMDA receptor-mediated currents in the CA3 region of the guinea pig hippocampus." Neuropeptides 32(1): 87-95.

Caudle, R. M. and L. Isaac (1988). "A novel interaction between dynorphin(1-13) and an N-methyl-D-aspartate site." Brain Res 443(1-2): 329-32.

Chavkin, C., S. J. Henriksen, et al. (1985). "Selective inactivation of opioid receptors in rat hippocampus demonstrates that dynorphin-A and -B may act on mu-receptors in the CA1 region." Brain Res 331(2): 366-70.

Chavkin, C., I. F. James, et al. (1982). "Dynorphin is a specific endogenous ligand of the kappa opioid receptor." Science 215(4531): 413-5. 
Chehadeh, H. E., G. Zerlauth, et al. (1995). "Video image analysis of quantitative competitive PCR products: comparison of different evaluation methods." Biotechniques 18(1): 26, 28.

Cody, F. W., R. W. Lee, et al. (1972). "A functional analysis of the components of the mesencephalic nucleus of the fifth nerve in the cat." J Physiol 226(1): 249-61.

Connor, M. and M. J. Christie (1998). "Modulation of Ca2+ channel currents of acutely dissociated rat periaqueductal grey neurons." J Physiol (Lond) 509(Pt 1): 47-58.

Cook, S. P., L. Vulchanova, et al. (1997). "Distinct ATP receptors on pain-sensing and stretch-sensing neurons." Nature 387(6632): 505-8.

Cooper, B. Y., C. J. Vierck, Jr., et al. (1986). "Selective reduction of second pain sensations by systemic morphine in humans." Pain 24(1): 93-116.

Corbin, K. B. and F. Harrison (1940). "Function of mesencephalic root of fifth cranial nerve." Journal of Neurophysiology 3: 423-435.

Cox, B. M., K. E. Opheim, et al. (1975). "A peptide-like substance from pituitary that acts like morphine. 2. Purification and properties." Life Sci 16(12): 1777-82.

Dickenson, A. H., V. Chapman, et al. (1997). "The pharmacology of excitatory and inhibitory amino acid-mediated events in the transmission and modulation of pain in the spinal cord." Gen Pharmacol 28(5): 633-8.

Djouhri, L., L. Bleazard, et al. (1998). "Association of somatic action potential shape with sensory receptive properties in guinea-pig dorsal root ganglion neurones." $\underline{\mathrm{J}}$ Physiol 513 ( Pt 3): 857-72. 
Eckert, S. P., A. Taddese, et al. (1997). "Isolation and culture of rat sensory neurons having distinct sensory modalities [published erratum appears in J Neurosci Methods 1998 Dec 31;86(1):101]." J Neurosci Methods 77(2): 183-90.

Edwall, L. and L. Olgart (1977). "A new technique for recording of intradental sensory nerve activity in man." Pain 3(2): 121-5.

Elde, R., U. Arvidsson, et al. (1995). "Distribution of neuropeptide receptors. New views of peptidergic neurotransmission made possible by antibodies to opioid receptors." Ann N Y Acad Sci 757: 390-404.

Evans, C. J., D. E. Keith, Jr., et al. (1992). "Cloning of a delta opioid receptor by functional expression." Science 258(5090): 1952-5.

Fields, H. L. (1987). Pain. New York, McGraw-Hill Book Co.

Fors, U., M. L. Ahlquist, et al. (1984). "Relation between intradental nerve activity and estimated pain in man--a mathematical model." Pain 18(4): 397-408.

Fors, U. G., L. G. Edwall, et al. (1988). "The ability of a mathematical model to evaluate the effects of two pain modulating procedures on pulpal pain in man." $\underline{\text { Pain }} \mathbf{3 3}(2)$ : 253-64.

Gilliland, G., S. Perrin, et al. (1990). "Analysis of cytokine mRNA and DNA: detection and quantitation by competitive polymerase chain reaction." Proc Natl Acad Sci U S A 87(7): 2725-9.

Goldstein, A. and A. Naidu (1989). "Multiple opioid receptors: ligand selectivity profiles and binding site signatures." Mol Pharmacol 36(2): 265-72. 
Grudt, T. J. and G. Henderson (1998). "Glycine and GABAA receptor-mediated synaptic transmission in rat substantia gelatinosa: inhibition by mu-opioid and GABAB agonists." J Physiol (Lond) 507(Pt 2): 473-83.

Grudt, T. J. and J. T. Williams (1993). "kappa-Opioid receptors also increase potassium conductance." Proc Natl Acad Sci U S A 90(23): 11429-32.

Grudt, T. J. and J. T. Williams (1994). "mu-Opioid agonists inhibit spinal trigeminal substantia gelatinosa neurons in guinea pig and rat." J Neurosci 14(3 Pt 2): 164654.

Grudt, T. J. and J. T. Williams (1995). "Opioid receptors and the regulation of ion conductances." Rev Neurosci 6(3): 279-86.

Hamill, O. P., A. Marty, et al. (1981). "Improved patch-clamp techniques for highresolution current recording from cells and cell-free membrane patches." $\underline{\text { Pflugers }}$ Arch 391(2): 85-100.

Harper, A. A. and S. N. Lawson (1985). "Conduction velocity is related to morphological cell type in rat dorsal root ganglion neurones." J Physiol 359: 31-46.

Hayes, A. G., P. P. Birch, et al. (1988). "Evidence that the kappa agonist U50488H has non-opioid actions." J Pharm Pharmacol 40(10): 718-20.

Heid, C. A., J. Stevens, et al. (1996). "Real time quantitative PCR." Genome Res 6(10): 986-94.

Herlitze, S., D. E. Garcia, et al. (1996). "Modulation of Ca2+ channels by G-protein beta gamma subunits." Nature 380(6571): 258-62.

Hildebrand, C., K. Fried, et al. (1995). "Teeth and tooth nerves." Prog Neurobiol 45(3): $165-222$. 
Horn, R. and A. Marty (1988). "Muscarinic activation of ionic currents measured by a new whole-cell recording method." J Gen Physiol 92(2): 145-59.

Huidobro-Toro, J. P., K. Yoshimura, et al. (1981). "Dynorphin interaction at the kappaopiate site." Eur J Pharmacol 72(2-3): 265-6.

Iadarola, J. M. and R. M. Caudle (1997). "Good pain, bad pain." Science 278(5336): 23940.

Ikeda, S. R. (1996). "Voltage-dependent modulation of N-type calcium channels by Gprotein beta gamma subunits." Nature 380(6571): 255-8.

Ingram, S., T. J. Wilding, et al. (1997). "Efficacy and kinetics of opioid action on acutely dissociated neurons." Mol Pharmacol 52(1): 136-43.

James, I. F., C. Chavkin, et al. (1982). "Selectivity of dynorphin for kappa opioid receptors." Life Sci 31(12-13): 1331-4.

Jessell, T. M. and L. L. Iversen (1977). "Opiate analgesics inhibit substance P release from rat trigeminal nucleus." Nature 268(5620): 549-51.

Jonas, P., C. Racca, et al. (1994). "Differences in Ca2+ permeability of AMPA-type glutamate receptor channels in neocortical neurons caused by differential GluR-B subunit expression." Neuron 12(6): 1281-9.

Jordan, B. A. and L. A. Devi (1999). "G-protein-coupled receptor heterodimerization modulates receptor function." Nature 399(6737): 697-700.

Jurna, I. and G. Heinz (1979). "Differential effects of morphine and opioid analgesics on A and $\mathrm{C}$ fibre-evoked activity in ascending axons of the rat spinal cord." $\underline{\text { Brain }}$ $\underline{\operatorname{Res}}$ 171(3): 573-6. 
Jyvasjarvi, E. and K. D. Kniffki (1987). "Cold stimulation of teeth: a comparison between the responses of cat intradental $\mathrm{A}$ delta and $\mathrm{C}$ fibres and human sensation." J Physiol 391: 193-207.

Kieffer, B. (2000). "Opioid receptors: from genes to mice." The Journal of Pain 1(45-50).

Kieffer, B. L. (1999). "Opioids: first lessons from knockout mice." Trends Pharmacol Sci 20(1): 19-26.

King, A. P., K. E. Hall, et al. (1999). "kappa- and mu-Opioid inhibition of N-type calcium currents is attenuated by 4 beta-phorbol 12-myristate 13 -acetate and protein kinase $\mathrm{C}$ in rat dorsal root ganglion neurons." $\mathrm{J}$ Pharmacol Exp Ther 289(1): 312-20.

Kirschstein, T., W. Greffrath, et al. (1999). "Inhibition of rapid heat responses in nociceptive primary sensory neurons of rats by vanilloid receptor antagonists." $\underline{J}$ Neurophysiol 82(6): 2853-60.

Kohno, T., E. Kumamoto, et al. (1999). "Actions of opioids on excitatory and inhibitory transmission in substantia gelatinosa of adult rat spinal cord." $\underline{\mathrm{J} \text { Physiol (Lond) }}$ 518(Pt 3): 803-13.

Kyrozis, A. and D. B. Reichling (1995). "Perforated-patch recording with gramicidin avoids artifactual changes in intracellular chloride concentration." J Neurosci Methods 57(1): 27-35.

Lahti, R. A., M. M. Mickelson, et al. (1985). "[3H]U-69593 a highly selective ligand for the opioid kappa receptor." Eur J Pharmacol 109(2): 281-4. 
Lee, K. H., K. Chung, et al. (1986). "Correlation of cell body size, axon size, and signal conduction velocity for individually labelled dorsal root ganglion cells in the cat." J Comp Neurol 243(3): 335-46.

Lewis, T. and E. Pochin (1937). "The double pain response of the human skin to a single stimulus." Clinical Science 3: 67-76.

Li, X., D. E. Keith, Jr., et al. (1996). "Multiple opioid receptor-like genes are identified in diverse vertebrate phyla." FEBS Lett 397(1): 25-9.

Light, A. R. and E. R. Perl (1979). "Spinal termination of functionally identified primary afferent neurons with slowly conducting myelinated fibers." 186(2): 133-50.

Light, A. R. and H. H. Willcockson (1999). "Spinal laminae I-II neurons in rat recorded in vivo in whole cell, tight seal configuration: properties and opioid responses." $\underline{\mathbf{J}}$ Neurophysiol 82(6): 3316-26.

Liu, N. J., T. Xu, et al. (1995). "Cholecystokinin octapeptide reverses mu-opioidreceptor-mediated inhibition of calcium current in rat dorsal root ganglion neurons." J Pharmacol Exp Ther 275(3): 1293-9.

Machelska, H. and C. Stein (2000). "Pain control by immune-derived opioids." Clin Exp Pharmacol Physiol 27(7): 533-6.

Massotte, D. and B. L. Kieffer (1998). "A molecular basis for opiate action." Essays Biochem 33: 65-77.

Matthes, H. W., R. Maldonado, et al. (1996). "Loss of morphine-induced analgesia, reward effect and withdrawal symptoms in mice lacking the mu-opioid-receptor gene [see comments]." Nature 383(6603): 819-23. 
McCleskey, E. W. and M. S. Gold (1999). "Ion channels of nociception." $\underline{\text { Annu Rev }}$ Physiol 61: 835-56.

Moises, H. C., K. I. Rusin, et al. (1994). "Mu- and kappa-opioid receptors selectively reduce the same transient components of high-threshold calcium current in rat dorsal root ganglion sensory neurons." J Neurosci 14(10): 5903-16.

Moises, H. C., K. I. Rusin, et al. (1994). "mu-Opioid receptor-mediated reduction of neuronal calcium current occurs via a G(o)-type GTP-binding protein." J Neurosci 14(6): 3842-51.

Nagy, I. and H. Rang (1999). "Noxious heat activates all capsaicin-sensitive and also a sub-population of capsaicin-insensitive dorsal root ganglion neurons." Neuroscience 88(4): 995-7.

Narhi, M., H. Yamamoto, et al. (1994). "The neurophysiological basis and the role of inflammatory reactions in dentine hypersensitivity." Arch Oral Biol 39 Suppl: 23S-30S.

Pasternak, G. W. (2001). "Insights into mu opioid pharmacology the role of mu opioid receptor subtypes." Life Sci 68(19-20): 2213-9.

Portoghese, P. S., A. W. Lipkowski, et al. (1987). "Binaltorphimine and norbinaltorphimine, potent and selective kappa- opioid receptor antagonists." Life Sci 40(13): 1287-92.

Price, D. D., J. W. Hu, et al. (1977). "Peripheral suppression of first pain and central summation of second pain evoked by noxious heat pulses." Pain 3(1): 57-68.

Price, D. D., A. Von der Gruen, et al. (1985). "A psychophysical analysis of morphine analgesia." Pain 22(3): 261-9. 
Randic, M., M. Kolaj, et al. (1995). "Interaction of neuropeptides and excitatory amino acids in the rat superficial spinal dorsal horn." Prog Brain Res 104: 225-53.

Raynor, K., H. Kong, et al. (1994). "Pharmacological characterization of the cloned kappa-, delta-, and mu- opioid receptors." Mol Pharmacol 45(2): 330-4.

Rudling, J. E., J. Richardson, et al. (2000). "A comparison of agonist-specific coupling of cloned human alpha(2)-adrenoceptor subtypes." Br J Pharmacol 131(5): 933-41.

Rusin, K. I. and H. C. Moises (1995). "mu-Opioid receptor activation reduces multiple components of high- threshold calcium current in rat sensory neurons." J Neurosci 15(6): 4315-27.

Samoriski, G. M. and R. A. Gross (2000). "Functional compartmentalization of opioid desensitization in primary sensory neurons." J Pharmacol Exp Ther 294(2): 500-9.

Sarkar, P. and P. Feigelson (1989). "Developmentally regulated male-specific transfactor(s) enable in vitro transcription of a cloned alpha $2 \mathrm{u}$-globulin gene." Mol Endocrinol 3(2): 342-8.

Schroeder, J. E., P. S. Fischbach, et al. (1991). "Activation of mu opioid receptors inhibits transient high- and low- threshold $\mathrm{Ca} 2+$ currents, but spares a sustained current." Neuron 6(1): 13-20.

Sengupta, J., A. Snider, et al. (1999). "Effects of kappa opioids on the inflamed rat colon." Pain 79(2-3): 175-85.

Sora, I., N. Takahashi, et al. (1997). "Opiate receptor knockout mice define mu receptor roles in endogenous nociceptive responses and morphine-induced analgesia." Proc Natl Acad Sci U S A 94(4): 1544-9. 
Stein, C., H. Machelska, et al. (2001). "Peripheral opioid analgesia." Curr Opin Pharmacol 1(1): 62-5.

Su, X., J. Sengupta, et al. (1997). "Effects of kappa opioid receptor-selective agonists on responses of pelvic nerve afferents to noxious colorectal distension." Journal of physiology 78(2): 1003-12.

Su, X., R. E. Wachtel, et al. (1998). "Inhibition of calcium currents in rat colon sensory neurons by K- but not mu- or delta-opioids." J Neurophysiol 80(6): 3112-9.

Sucher, N. J. and D. L. Deitcher (1995). "PCR and patch-clamp analysis of single neurons." Neuron 14(6): 1095-100.

Taddese, A., S. Y. Nah, et al. (1995). "Selective opioid inhibition of small nociceptive neurons." Science 270(5240): 1366-9.

Tajima, Y., K. Ono, et al. (1996). "Perforated patch-clamp recording in cardiac myocytes using cation- selective ionophore gramicidin." Am J Physiol 271(2 Pt 1): C52432.

Tang, Q., R. M. Lynch, et al. (2000). "Dynorphin A elicits an increase in intracellular calcium in cultured neurons via a non-opioid, non-NMDA mechanism [In Process Citation]." J Neurophysiol 83(5): 2610-5.

Teschemacher, H., K. E. Opheim, et al. (1975). "A peptide-like substance from pituitary that acts like morphine. I. Isolation." Life Sci 16(12): 1771-5.

Tkatch, T., G. Baranauskas, et al. (2000). "Kv4.2 mRNA abundance and A-type K(+) current amplitude are linearly related in basal ganglia and basal forebrain neurons." J Neurosci 20(2): 579-88. 
Torebjork, H. E. and R. G. Hallin (1973). "Perceptual changes accompanying controlled preferential blocking of A and C fibre responses in intact human skin nerves." Exp Brain Res 16(3): 321-32.

Trafton, J. A., C. Abbadie, et al. (1999). "Spinal opioid analgesia: how critical is the regulation of substance P signaling?" J Neurosci 19(21): 9642-53.

Utz, J., R. Eckert, et al. (1995). "Inhibition of L-type calcium currents in guinea pig ventricular myocytes by the kappa-opioid agonist U50488H does not involve binding to opiate receptors." Journal Of Pharmacology And Experimental Therapeutics 274(2): 627-33.

Vanderah, T. W., L. R. Gardell, et al. (2000). "Dynorphin promotes abnormal pain and spinal opioid antinociceptive tolerance." J Neurosci 20(18): 7074-9.

Vaughan, C. W. and M. J. Christie (1997). "Presynaptic inhibitory action of opioids on synaptic transmission in the rat periaqueductal grey in vitro." J Physiol (Lond) 498(Pt 2): 463-72.

Voilley, N., J. de Weille, et al. (2001). "Nonsteroid anti-inflammatory drugs inhibit both the activity and the inflammation-induced expression of acid-sensing ion channels in nociceptors." J Neurosci 21(20): 8026-33.

Wall, P. D. and C. J. Woolf (1984). "Muscle but not cutaneous C-afferent input produces prolonged increases in the excitability of the flexion reflex in the rat." J Physiol (Lond) 356: 443-58.

Wang, Z., L. R. Gardell, et al. (2001). "Pronociceptive actions of dynorphin maintain chronic neuropathic pain." J Neurosci 21(5): 1779-86. 
Waxman, S. G., T. R. Cummins, et al. (1999). "Sodium channels, excitability of primary sensory neurons, and the molecular basis of pain." Muscle Nerve 22(9): 1177-87.

Werz, M. A. and R. L. MacDonald (1983). "Opioid peptides selective for mu- and deltaopiate receptors reduce calcium-dependent action potential duration by increasing potassium conductance." Neurosci Lett 42(2): 173-8.

Whistler, J. L., H. H. Chuang, et al. (1999). "Functional dissociation of mu opioid receptor signaling and endocytosis: implications for the biology of opiate tolerance and addiction." Neuron 23(4): 737-46.

Wilding, T. J., M. D. Womack, et al. (1995). "Fast, local signal transduction between the mu opioid receptor and Ca2+ channels." J Neurosci 15(5 Pt 2): 4124-32.

Williams, J. T., M. J. Christie, et al. (2001). "Cellular and synaptic adaptations mediating opioid dependence." Physiol Rev 81(1): 299-343.

Williams, J. T., M. J. Christie, et al. (1987). "Potentiation of enkephalin action by peptidase inhibitors in rat locus ceruleus in vitro." J Pharmacol Exp Ther 243(1): 397-401.

Williams, J. T., T. M. Egan, et al. (1982). "Enkephalin opens potassium channels on mammalian central neurones." Nature 299(5878): 74-7.

Williams, J. T. and R. A. North (1984). "Opiate-receptor interactions on single locus coeruleus neurones." Mol Pharmacol 26(3): 489-97.

Woolf, C. J. (1996). "Phenotypic modification of primary sensory neurons: the role of nerve growth factor in the production of persistent pain." Philos Trans R Soc Lond B Biol Sci 351(1338): 441-8. 
Woolf, C. J. and M. W. Salter (2000). "Neuronal plasticity: increasing the gain in pain." Science 288(5472): 1765-9.

Woolf, C. J. and P. D. Wall (1986). "Morphine-sensitive and morphine-insensitive actions of C-fibre input on the rat spinal cord." Neurosci Lett 64(2): 221-5.

Wuster, M., P. Rubini, et al. (1981). "The preference of putative pro-enkephalins for different types of opiate receptors." Life Sci 29(12): 1219-27.

Wymore, R. S., D. Negulescu, et al. (1996). "Characterization of the transcription unit of mouse Kv1.4, a voltage-gated potassium channel gene." J Biol Chem 271(26): $15629-34$

Xu, H., J. E. Dixon, et al. (1996). "Developmental analysis reveals mismatches in the expression of $\mathrm{K}+$ channel alpha subunits and voltage-gated $\mathrm{K}+$ channel currents in rat ventricular myocytes." J Gen Physiol 108(5): 405-19.

Yaksh, T. L. (1999). "Regulation of spinal nociceptive processing: where we went when we wandered onto the path marked by the gate." Pain Suppl 6: S149-52.

Yaksh, T. L., T. M. Jessell, et al. (1980). "Intrathecal morphine inhibits substance P release from mammalian spinal cord in vivo." Nature 286(5769): 155-7.

Yeomans, D. C., V. Pirec, et al. (1996). "Nociceptive responses to high and low rates of noxious cutaneous heating are mediated by different nociceptors in the rat: behavioral evidence." Pain 68(1): 133-40.

Yoshimura, M. and R. A. North (1983). "Substantia gelatinosa neurones hyperpolarized in vitro by enkephalin." Nature 305(5934): 529-30.

Yuh, C. H., H. Bolouri, et al. (1998). "Genomic cis-regulatory logic: experimental and computational analysis of a sea urchin gene." Science 279(5358): 1896-902. 
Yuh, C. H. and E. H. Davidson (1996). "Modular cis-regulatory organization of Endo16, a gut-specific gene of the sea urchin embryo." Development 122(4): 1069-82.

Zhang, S., Y. Tong, et al. (1998). "Dynorphin A as a potential endogenous ligand for four members of the opioid receptor gene family." J Pharmacol Exp Ther 286(1): 13641.

Zhang, X., L. Bao, et al. (1998). "Localization and regulation of the delta-opioid receptor in dorsal root ganglia and spinal cord of the rat and monkey: evidence for association with the membrane of large dense-core vesicles." Neuroscience 82(4): $1225-42$ 